\title{
DRAFT ENVIRONMENTAL IMPACT REPORT: CITY OF CLEARLAKE GENERAL PLAN UPDATE
}

\author{
A Project Report \\ presented to \\ the Faculty of California Polytechnic State University, \\ San Luis Obispo
}

In Partial Fulfillment of the Requirements for the Degree Master of City and Regional Planning

By

Hannah Cha

June 2014 
(C) 2014

Hannah Cha

ALL RIGHTS RESERVED 
COMMITTEE MEMBERSHIP

TITLE:

Draft Environmental Impact Report: City of Clearlake General Plan Update

AUTHOR: Hannah Cha

DATE SUBMITTED: June 2014

COMMITEE CHAIR: W. David Conn, D. Phil.

Professor of City and Regional Planning

COMMITTEE MEMBER: Paul Wack, Ph. D., AICP

Professor of City and Regional Planning

COMMITTEE MEMBER: Trevor Keith, MCRP

Energy Program Coordinator, San Luis Obispo County 


\section{ABSTRACT \\ Draft Environmental Impact Report: City of Clearlake General Plan Update Hannah Cha}

The City of Clearlake in northern California initiated its first general plan update in 2012. The City decided to do an Environmental Impact Report (EIR) for the general plan update in order to fulfill the California Environmental Quality Act's (CEQA) requirements. The author wrote the Agriculture and Biological Resources sections of the EIR. She explains the CEQA process for a programmatic-level EIR, and summarizes the lessons learned and recommendations for CEQA.

General CEQA issues include fear of litigation and vague requirements for thresholds of significance. Additional CEQA issues include difficulty applying the same level of analysis to programmatic projects when the Environmental Checklist is more applicable for smallscale projects; difficulty identifying the extent of analysis needed; and the cost and time burdens of preparing programmatic-level EIRs. Recommendations for future programmaticlevel EIRs and CEQA reform conclude the paper.

Keywords: California Environmental Quality Act, Environmental Impact Report 


\section{ACKNOWLEDGMENTS}

Several people made this professional project possible. The committee chair, W. David Conn, provided valuable advice and direction for the project.

The committee members, Paul Wack and Trevor Keith, also provided key advice during the entire project process. Professor Paul Wack fielded my agricultural questions, and Trevor Keith fielded my biological resources questions.

During the professional project process, Professor Cornelius Nuworsoo and the Clearlake General Plan Update EIR team supported the project through various meetings and edits. The City of Clearlake's staff provided local knowledge to the project as well. 


\section{TABLE OF CONTENTS}

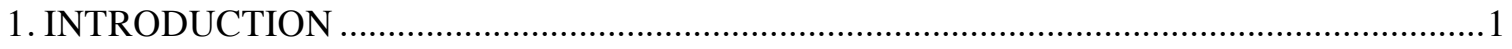

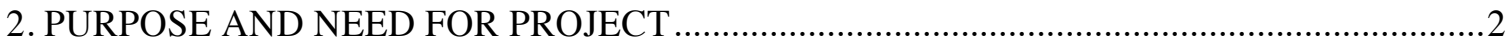

California Environmental Quality Act Framework .......................................................2

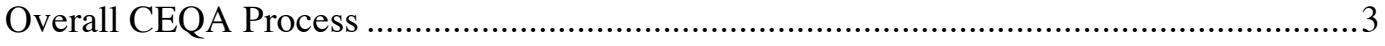

City of Clearlake General Plan Update EIR process ........................................................4

3. ISSUES WITH DRAFT ENVIRONMENTAL IMPACT REPORT .........................................6

General Issues with CEQA: Overview of CEQA procedures ........................................6

Specific Issues with CEQA: Programmatic-level Environmental Impact Report................7

4. LESSONS LEARNED \& RECOMMENDATIONS …............................................................ 10

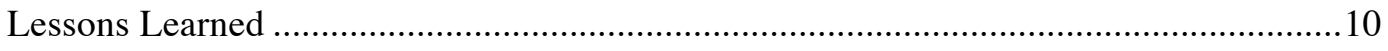

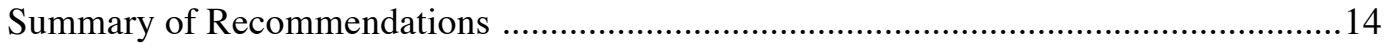

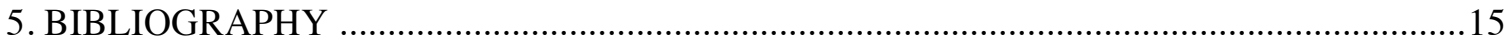

APPENDICES

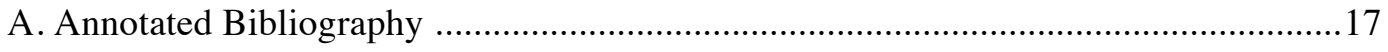

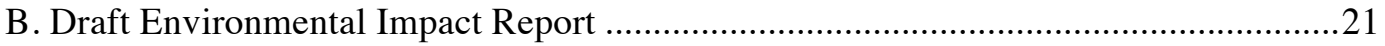




\section{Introduction}

General plans are the heart of city planning in California. In 2012 the City of Clearlake started its general plan update process. Clearlake's first General Plan was created in 1983, soon after the City was incorporated. The City's leaders wanted to update their vision and policies, since the first General Plan was not updated since its first adoption. In early 2013 a draft of General Plan Update was completed, and the City determined that an Environmental Impact Report (EIR) was needed before the City can decide whether or not to adopt the Plan. The Environmental Impact Report is an important analysis of the General Plan Update's potential impact on the environment that will help the City and its residents to decide on its adoption. The EIR document may also help shape the contents of the final General Plan Update document.

This report concentrates on the EIR portion of the California Environmental Quality Act (CEQA) process. First-hand experience of working on the EIR revealed several issues with CEQA. This report reviews parts of the CEQA process, analyzes its effectiveness and makes recommendations based on lessons learned from preparing the EIR for the City of Clearlake General Plan Update. 


\section{Purpose and Need for Project}

California law requires cities and counties to adopt a general plan. The general plan is the foundation upon which all land use decisions are based (California Governor's Office of Planning and Research (OPR), 2003). Clearlake's most current general plan was also its first plan, completed in 1983 after the City was incorporated (Cal Poly Graduate Studio Planning Team, 2012). The City has seen many changes since the general plan was adopted; in a 10-year time period from 2000 to 2010 , the City of Clearlake's population grew by $16.04 \%$ in comparison to the State of California's $9.99 \%$ growth (World Media Group, LLC, 2014). The City hopes to boost its economic sector and better reflect its current community through updating its general plan.

Pioneers settled in the City of Clearlake and its surrounding areas in the $19^{\text {th }}$ century. Clear Lake attracted the wealthy with luxury resorts and hot springs. However, before the City was incorporated, tourism in Clearlake declined. Clearlake's economy is characterized mainly by service jobs, and the City lacks a major employment center. Since its incorporation in 1980, the City's economic base has shifted to small commercial operations, and the City lacks a cohesive community vision reflective of its current state. Community feedback from the General Plan Update outreach identified that residents desired for the City of Clearlake to become a retail center and a vacation destination (Cal Poly Graduate Studio Planning Team, 2012).

\section{California Environmental Quality Act Framework}

CEQA's primary intent is to disclose potential environmental impacts to the public and to decisionmakers. CEQA Public Resources Code Section 21000 et seq., and the State CEQA Guidelines, Title 14 California Code of Regulations (CCR) Section 15000 et seq. (California, State of, 1970b, as amended) compel public agencies to use their judgment in deciding which projects may have adverse impact on the environment. If a public agency determines that a project could potentially have significant environmental impacts, the project must provide documentation of those impacts for consideration by decision-makers and the public. The public agency with final approval authority over an action is called the "lead agency".

State CEQA Guidelines Section 15367 states that a lead agency has the principal responsibility of carrying out or approving a project. The City of Clearlake is the lead agency for this project, because the City is responsible for the General Plan update. Ultimately, the City will determine whether to adopt the 
General Plan update or not.

Overall CEQA Process

There are four general steps in the CEQA process:

1. Preliminary review

2. Prepare initial study

3. Prepare Negative Declaration, Mitigated Negative Declaration, or Environmental Impact Report.

4. Decision making

(The Planning Center and DC\&E, 2012)

In the first step, the lead agency must determine if the proposed activity is a "project" as defined by CEQA. A project, as defined in section 15378 of the CEQA Guidelines, is an action that requires discretionary action; has potential to change the physical environment; is a public agency action; is supported by a public agency; or requires a lease, permit, license, certification, or entitlement from a public agency. According to CEQA's definition of a project, general plans are considered a project. A general plan receives discretionary approval from a local government agency and the plan may cause a direct physical change in the environment or a reasonably foreseeable indirect change in the environment (California, State of, 1970b). A general plan is different from most other CEQA projects, because it is considered a legislative act (Fulton, 1999). Therefore in order to update the General Plan the City of Clearlake was required to follow the CEQA process.

Certain projects are statutorily exempted from CEQA review by the state legislature. The state legislature can decide to exempt certain projects that they consider to have benefits outweighing potential costs, such as Olympic Games facilities construction and emergency projects. Projects can also be categorically exempted, if they are listed as a type that is considered to have low potential impacts on the environment under CEQA guidelines 15300-33. If the project is not exempt, the CEQA review goes on to step two.

Step two is the initial study (IS), which determines whether the project would potentially have a significant impact on the environment and if an EIR is needed. However, the lead agency may decide to skip the IS and just proceed with the EIR. In step three the lead agency produces an EIR, a negative 
declaration or a mitigated negative declaration. The City of Clearlake decided to proceed with an EIR. After the document is produced, the lead agency must circulate the Notice of Completion and Draft EIR for public review for 30-45 days. The comments from the public review are incorporated, together with responses, into the Final EIR. Then the Final EIR can be certified by the lead agency. Only after it has been certified, can the lead agency make a decision on whether or not to adopt the general plan.

Before a project with any significant impacts can be approved, each significant impact must be defended through the "findings". A "finding" is the reasoning behind any changes or alternatives incorporated into the project to avoid or reduce impact, mitigation or changes under another agency's jurisdiction, and specific reasons why mitigation measures or alternatives are infeasible. After a project receives approval, the agency files a Notice of Determination (NOD) with the State Clearinghouse and the county clerk. The decision-making body must prepare a Statement of Overriding Considerations, if the approved project has any significant, unavoidable impacts. The Statement of Overriding Considerations is a statement with the specific reason why the benefits of the project outweigh the potential significant environmental impacts and the evidence to support the reasoning. After the NOD is filed, for 30 days anyone can file a court case challenging the process.

\section{City of Clearlake General Plan Update EIR process}

The bulk of the professional project conducted by the author pertains to the period after the City decided to prepare an EIR and up to the completion of the Draft EIR document. This process included several other tasks for the EIR team, such as: writing the Notice of Preparation (NOP), receiving comments on NOP, replying to comments, and writing other sections of the document (i.e. Introduction, Alternatives, and Project Description). The core EIR process the Author conducted was: 1. Review CEQA’s Appendix G: Environmental Checklist Form.

2. Review General Plan update and background report for General Plan update.

3. Review examples of EIR for General Plan updates for different cities. Look at their methodology for analyzing data and whether and how they established thresholds of significance. Note that different general plan EIRs may be based on different thresholds adopted by different agencies.

4. Obtain information and write the background report on the topic of interest.

5. Identify potential impacts for each topic using the CEQA guideline's Appendix G: Environmental 
Checklist Form as a starting point.

6. Analyze the impacts.

7. Make a judgment about level of significance for each potential impact.

8. Analyze the accumulative environmental impacts for each section.

9. Create supporting tables and maps.

10. Edit for consistency throughout the document. 


\section{Issues with Draft Environmental Impact Report}

\section{General Issues with CEQA: Overview of CEQA procedures}

CEQA's primary objective is to disclose potential environmental impacts to the public and to decision-makers. CEQA is criticized because it slows development through environmental reviews and occasionally through litigation (O'Reilly, 1993). Although a survey by the Association of Bay Area Governments (ABAG) found that less than one percent of all project applications result in a lawsuit, many of those involved in CEQA have stated that litigation is a primary concern during the process of creating EIRs (O'Reilly, 1993). This fear of litigation forces the documents to be overly technical and difficult to use in the decision-making process they were initially created for (O'Reilly, 1993).

Litigation has become a strategy for some Not In My Backyard (NIMBY) citizens to delay controversial projects. For self-interested reasons, NIMBY groups oppose projects that impact their neighborhoods' status quo, and these groups utilize several methods, such as litigation, to prevent development. Although the true motive of the lawsuits challenging CEQA documents is difficult to identify, many lawsuits can effectively kill or at least slow down a project due to high legal costs and the costs associated with tying up land during stalled projects.

These lawsuits often take advantage of CEQA's vague wording and lack of standards of significance. CEQA was intentionally written so that it is applicable to various types of projects. A project's environmental impact may vary according to its context, so CEQA leaves it up to the lead agency to appropriately apply CEQA. This subjective language has created a system in which the courts ultimately determine which impacts are considered "significant," and this perpetuates the fear of litigation and is highly time-consuming (O’Reilly, 1993).

The fear of lawsuits has grown, so that CEQA can even hinder prospective projects from taking shape. Even plans intended to increase the sustainability of communities, such as bike transportation plans, have been stalled through CEQA-based lawsuits. Minor issues concerning a project could sometimes supersede the project's overall positive intents. The purpose of a bike transportation plan is typically to provide infrastructure for bicyclists, and as a result it may reduce the number of automobiles on the roads. However, through the CEQA lens the construction of bicycle lanes may contribute to environmental impacts through increased automobile traffic (less lanes for 
automobiles), or construction of medians. This particular issue with CEQA was resolved in 2013 when Governor Brown signed AB 417, which created a CEQA exemption for bicycle transportation plans (California Legislative Information, n.d.). This is just one of many issues that planners and developers have come up against with CEQA. CEQA continues to be amended as issues are identified.

CEQA guidelines must be updated every two years. However, the constant revision and amendment of the CEQA guidelines are costly to agencies and developers who have to adapt to the ever-changing guidelines (O’Reilly, 1993). This is an inefficient system that keeps agencies and developers in constant apprehension of litigation. Due to high costs and time-constraints, CEQA is changing how long-range planning is done in some local governments. More general plan updates are done in a piecemeal manner in order to keep costs manageable. This type of general plan updates may create a less cohesive document, because the updates are completed at different phases (Barbour and Teitz, 2005). “CEQA's project-level focus does not support the most effective planning for the environment or for urban development” (Barbour and Teitz, 2005, p. 35).

\section{Specific Issues with CEQA: Programmatic-level Environmental Impact Report}

CEQA statutes do not specify thresholds of significance. The CEQA guidelines provide an Environmental Checklist Form (Appendix G), but purposefully leave the responsibility to the lead agency to determine the threshold of significance. Appendix G provides the questions that the lead agency needs to ask in order to decide whether an impact is considered significant or not.

CEQA authorizes and encourages local agencies to adopt local thresholds to help determine the environmental significance of an impact, but the City of Clearlake, like many other local governments, didn't have an adopted set of thresholds of significance (Seiver \& Hatfield, 2001). Santa Barbara County is one of the few jurisdictions that have adopted thresholds of significance (County of Santa Barbara Planning and Development, 2008). The author used other EIR documents, like the City of Newark's EIR, to suggest thresholds that might be appropriate for use in Clearlake. Although Newark's did not have an adopted threshold of significance, Newark's EIR was selected because of its thoroughness and overall high quality analysis in comparison to other documents reviewed.

If a local agency doesn't have established thresholds of significance, thresholds of significance are determined for each project. This lack of standardization creates duplication of efforts, and may 
make projects more susceptible to litigation. If a level of significance is contested, it's up to the courts to determine if it was appropriately chosen. This vague standard leaves public agencies and developers especially vulnerable to lawsuits. The fear of litigation may lead to an EIR full of legal language that is difficult to understand. A legalese EIR document defeats the purpose of an EIR to educate policymakers and the public.

During the writing of Clearlake's General Plan Update's EIR the author found that the CEQA guideline's Appendix G, by asking appropriate questions, may be helpful in developing thresholds of significance for smaller projects. However, for a general plan update, the questions in the environmental checklist are less relevant, because the scale for programmatic projects is very different from that for project-level projects. General plans look at a large scale of time and large physical area, so the same threshold level of significance can't be applied to a small project EIR as a larger programmatic EIR. The current CEQA statute and guidelines are unclear about the different needs for programmatic-level and project-level EIRs.

A general plan is meant to create a vision for a city and seven elements are required by the State of California. Within these various elements different goals are created, and programs and policies are developed based on the goals. The analysis of all these programs and policies contributes to a complicated document based on scenarios created from limited data and using several assumptions. General plans are documents requiring continuous revision, and the EIRs don't take this factor into account. Additionally, most cities don't implement all of their programs and policies. However, the analysis assumes all the programs and policies will be implemented, and implemented to their fullest extent. These assumptions paint an extreme scenario that projects a worst-case or best-case scenario of the impact the General Plan Update will have on the environment. In reality, the General Plan Update is a guideline for the City and many programs and policies will not be fully implemented due to financial and political factors. The results and impacts of a long-range plan are difficult to forecast, because there are too many external variables that cannot be accounted for. In contrast, a project-level EIR paints a more accurate portrayal of the project's impact on the environment, because of its short-term tasks and limited stakeholders.

Long-range plans, like general plans, have many variables, so it is difficult to know when an 
analysis is accurate enough. When the author analyzed the Biological Resources section of the EIR, she obtained statewide data on sensitive ecosystems. Based on this data, large areas of the City were identified as sensitive habitats. Smaller projects may identify the potential environmental impact by performing biological surveys of the land to determine, for example, whether any endangered species are present. A similar extent of biological survey would not only be time-intensive, but costly for a citywide analysis. CEQA guideline's lack of standards for projects of different sizes unfairly burdens community and regional-level projects that may not have the ability to fully proceed with the same level of detail as a project that specifically proposes construction designs and directly results in that construction. 


\section{Lessons Learned \& Recommendations}

\section{Lessons Learned}

\section{The quality of programmatic-level EIRs may vary.}

Before starting to write the EIR for Clearlake's General Plan update, the author reviewed several programmatic-level EIRs. Examination of these EIRs from other cities' General Plans provided a broad base of knowledge of the level of analysis and quality expected in a General Plan EIR. During this process the author found that it is important to choose cautiously which document to use as a guide, since the level of analysis and quality may widely vary. For example, the level of biological resources impact discussion in a general plan update EIR from a city in central California was insufficient for the level of analysis the author needed to do for the City of Clearlake. This city's biological resources analysis only provided a general impact assessment and detailed only one of the potential impacts. The analysis covered the bare minimum necessary to answer the questions in CEQA's Appendix G: Environmental Checklist Form. The environmental conditions for Clearlake, like the proximity to a lake and natural preserve, required that an

in-depth analysis was needed. Therefore, another method of analysis with GIS maps was utilized to analyze the environmental impact.

Factors that influence the quality of an EIR include the availability of data and the different characteristics within a community.

Data availability

Cities with several large projects may have data available on detailed biological surveys obtained from project-level EIRs. Many of the larger cities whose programmatic-level EIRs the author reviewed reused biological surveys collected from previous project-level EIRs. However, the City of Clearlake didn't have any recent biological surveys, because there were no recent project-level EIRs completed within the City. Therefore, a different set of data from the California Department of Fish and Wildlife online Map Viewer program was used to analyze the biological resources present in Clearlake. Community characteristics

The City of Newark's General Plan update's EIR was a great guide (The Planning Center, 2013). However, the City of Clearlake needed to include agricultural resources as part of their analysis. The City of Newark determined not to include agricultural resources as part of their analysis, so the author reviewed 
programmatic-EIRs from other cities.

A city's physical characteristics and its economic conditions are important factors that can help identify which method of analysis is appropriate for the environmental impact analysis. A general plan proposing a suburban development in undeveloped lands has very different impacts on the environment from a general plan proposing an infill development. The City of Clearlake has no prime farmlands identified within its boundaries, so the level of analysis for this subject was minimal. For another city with a lot of prime farmlands, the type of analysis would need to adjust to include this topic within its analysis.

Every General Plan EIR should be tailored to fit local characteristics and needs. Each city has its own physical and community characteristics; it's important to tailor the analysis to be relevant to the community.

\section{To streamline the CEQA process, programmatic-level and project-level EIRs should have separate environmental checklists, and a standard guideline for developing CEQA's thresholds of significance should be adopted.}

Washington's State Environmental Policy Act (SEPA) sets a narrower project scope than CEQA. CEQA has a broad definition for a project: an action that requires discretionary action; has potential to change the physical environment; is a public agency action; is supported by a public agency; or requires a lease, permit, license, certification, or entitlement from a public agency. CEQA's "project” equivalent in SEPA is an "action". There are two types of "actions". Washington State Legislature 197-11-704 defines a "project action" as a decision on a specific project, such as a construction or management activity located in a defined geographic area (Washington State Legislature, 2003). "Non-project actions" are defined as decisions on policies, plans, or programs. Both actions follow the same SEPA procedure, but each Environmental Impact Statement (EIS) concentrates on slightly different topics. The project EIS concentrates on the local impact more so than the non-project EIS, which may concentrate on the broader impacts. This dual method of analysis of project-level and programmatic-level projects provides flexibility for local agencies (O’Reilly, 1993).

Additionally, the California Legislative Analyst's Office and the State Bar of California publicly support clarifying terms and requirements for CEQA's standards (Barbour and Teitz, 2005). Although CEQA "reformers" vary in the extent and type of standardization of CEQA preferred, reformers generally 
support strengthening the certainty of CEQA's standards (Barbour and Teitz, 2005). Adopting a statewide standard thresholds of significance is projected to provide many benefits, such as:

- Promote predictability and consistency in the environmental review process throughout the state.

- Reduce inefficiency of duplication of efforts by having each local agency create different thresholds of significance.

- More objective analysis and less public influence on controversial issues.

- Encourage better-designed projects that incorporate mitigation efforts due to availability of a "significance target".

(Letunic \& Ferrell, 2007)

Despite the many benefits of a standard threshold of significance for the entire state, a standard threshold of significance would be difficult to implement, because of the variety of ecosystems throughout the state. Each ecosystem may have different sensitivities and thresholds of significance. Therefore, CEQA should be amended to include better guidance in developing the threshold of significance, so that at least the thresholds have similar standards in comparison to each other.

Additionally, CEQA Guideline’s Appendix G should include an environmental checklist for programmatic-level EIRs separate from project-level EIRs. A separate environmental checklist for General Plan documents may help expedite the process and reduce nonessential analysis. General Plans aren't like most projects that undergo CEQA, and the current environmental checklist is more relevant to tangible projects that need this level of detail for their analysis. A substantive standard that focuses more on bigger picture impacts may work better for EIRs for General Plans.

\section{An inclusive stakeholder involvement process pays off.}

Even before the CEQA process began the Clearlake General Plan update process involved stakeholders through the Cal Poly Graduate Studio's community meetings and online presence. The background report produced by the Cal Poly Graduate Studio was essential in understanding current conditions (Cal Poly Graduate Studio Planning Team, 2012). The community's input in the report not only helped create a document reflective of the community's needs, but previous community involvement expedited the CEQA process of identifying stakeholders and communicating with them. The community's continuous involvement in the general plan update streamlined the CEQA process, since many of the 
stakeholders were already involved and were informed about the EIR for the general plan. The scoping meeting identifies the environmental issues that need to be discussed in the EIR. For Clearlake's EIR this scoping meeting took place during the general plan update process before the EIR team was assembled.

The notice of preparation (NOP) comments were incorporated into the Draft EIR and issues known by local experts were included as part of the analysis.

The CEQA statutes and guidelines have several requirements for stakeholder involvement. PRC Section 21080.4 and Guidelines Section 15082 require that the lead agency immediately send NOP of an EIR to all responsible agencies, trustee agencies, and the Office of Planning and Research (OPR). These stakeholder involvement requirements are an essential part of CEQA and reduce the likelihood of litigation. CEQA guidelines recommend additional public outreach, such as public meetings on the CEQA process (Guidelines Section 15202) and online publication of notices (Guidelines Sections 15062, 15075, 15085). Involving the public beyond the CEQA statute requirements creates a better EIR and, subsequently, a better overall project.

\section{The CEQA process is time-consuming, so planning ahead is essential for a project's}

\section{success.}

CEQA statutes and guidelines outline a procedure for agencies to follow. Some of these procedures require a minimum or maximum number of days. For example, the NOP requires that the lead agency immediately send notice of its determination to prepare an EIR to all responsible agencies, trustee agencies, and OPR. These agencies get 30 days to specify the scope and content of the environmental information relevant to their area of expertise.

The need to prepare an EIR document extends the CEQA process time frame, because an EIR document delves into more detail than the "other alternatives". For this project the researching, analyzing and writing portions of Clearlake's General Plan Update Draft EIR took approximately 6 months (this only includes time for the draft document not the final). This time consuming process equates to monetary costs that some projects may not be able to accommodate. Developers account for this expense in their pro forma, and local governments and agencies also should plan to invest their staff time or consultant time accordingly for a general plan EIR. This time approximation, again, varies depending on the extent of analysis and availability of data needed for the analysis. The optional scoping session, or other public 
involvement early on in the CEQA process may assist in planning for the CEQA process through identifying potential controversial issues.

Since the City of Clearlake General Plan Update EIR is still in its draft form, it is difficult to gauge the success of this project at this point. However, understanding the general timeline of the CEQA process and its requirements made the draft EIR process as smooth as possible. Before any of the research or analysis started, an approximate timeline including CEQA time requirements was developed. Other projects can learn from this project that following CEQA timelines and preparing financially for extended costs are important to a good project, especially if an EIR is required.

\section{Summary of Recommendations}

- Examine EIRs prepared for other city's general plans as a guide but take caution when choosing which documents to utilize.

- "Create a clear guideline for developing a standard thresholds of significance in the CEQA guidelines, and adopt a separate environmental checklist for programmatic-level projects in order to streamline the entire CEQA process.

- Involve stakeholders before and during the CEQA process.

- When undergoing the CEQA process, be prepared for the firm deadlines and incorporate potential costs for project delays. 


\section{Bibliography}

Barbour, E and Teitz, M. (2005). CEQA reform: issues and options. (Accessed: 4/11/14) Retrieved from http://www.ppic.org/content/pubs/op/OP 405EBOP.pdf

California Legislative Information (n.d.). AB-417 Environmental quality: California Environmental Quality Act: bicycle transportation plan. (Accessed 4/11/14) Retrieved from: http://leginfo.legislature.ca.gov/faces/billNavClient.xhtml?bill id=201320140AB417

Cal Poly Graduate Studio Planning Team (2012). City of Clearlake Background Report: City of Clearlake General Plan Update. Retrieved from: http://planclearlake.weebly.com/background-report.html

California Governor‘s Office of Planning and Research (2003). General Plan Guidelines. Retrieved from http://www.opr.ca.gov/planning/publications/General_Plan_Guidelines_2003.pdf

County of Santa Barbara Planning and Development (2008). Environmental Thresholds and Guidelines Manual. Retrieved from: http://www.sbcountyplanning.org/pdf/ManualsReports/Manuals/Environmental\%20Thresholds\%2 0October\%202008\%20corrected\%206-1-2009.pdf

Fulton, William B. (1999). Guide to California Planning. Point Arena, CA: Solano Press books.

Letunic, N. and Ferrell, C.E. Ph.D. (2007). CEQA thresholds of significance: A do-it-yourself guide for public agencies. American Planning Association. Retrieved from http://eisenletunic.com/news docs/Publication CEQAthresholds.pdf

O’Reilly, R. (1993). A primer on the California Environmental Quality Act. Pacific Research Institute (accessed: 4/11/14). Retrieved from http://special.pacificresearch.org/pub/sab/enviro/ceqa.html

PBS\&J (March 3, 2009). Sacramento 2030 General Plan Master Environmental Impact Report City Project \#M04-031, State Clearinghouse No.2007072024. Retrieved from http://www.sacgp.org/mastereir/documents/Part1 GPMasterEIR.pdf

Seiver, O.H. and Hatfield, T.H. (2001). The determination of the thresholds of environmental significance in the application of the California environmental quality act. Retrieved from http://www.csus.edu/calst/government affairs/reports/ffp43.pdf

State of California (1970a). California Environmental Quality Act, Public Resources Code Section 21000 et seq., 1970, as amended.

State of California (1970b). CEQA Guidelines, Title 14 California Code of Regulations (CCR) Section 15000 et seq., 1970, as amended.

The Planning Center (August 13, 2013). Newark General Plan Tune Up Draft EIR for the City of Newark: State Clearinghouse No.2013012052. Retrieved from http://www.newark.org/images/uploads/comdev/pdfs/GeneralPlan/NewarkGP DEIR PublicRevie $\underline{\text { w.pdf }}$

The Planning Center and DC\&E (2012). A practical guide to the California Environmental Quality Act.

Washington State Department of Ecology (n.d.). SEPA Online Handbook. Retrieved from http://www.ecy.wa.gov/programs/sea/sepa/handbk/hbintro.html 
Washington State Legislature (2003). WAC 197-11-704. Retrieved from

http://apps.leg.wa.gov/wac/default.aspx?cite=197-11-704

World Media Group, LLC (2014). Clearlake, CA population and races. (Accessed on 4/29/14).

Retrieved from www.usa.com/clearlake-ca-population-and-races.htm 


\section{Appendix A: Annotated Bibliography}

Cal Poly Graduate Studio Planning Team (December 7, 2012). Background Report: City of Clearlake General Plan Update. Retrieved from http://planclearlake.weebly.com/background-report.html

Provides comprehensive summary of existing conditions in the City of Clearlake. Research method varies with many sources of information from mainly secondary sources. The Background Report found that the agricultural resources are located mainly outside the city limits, and biological resources were listed through the California Fish \& Wildlife Database. This information provides the backbone to my research and points to other useful resources to use in my research.

Cal Poly Graduate Studio Planning Team (April 19, 2013). 2040 General Plan Update. Retrieved from http://planclearlake.weebly.com/general-plan-draft.html

The General Plan Update serves the community's goals and outlines policies to enforce these goals. The community goals were developed through several community outreach events and thorough background research on existing conditions and problems. The City of Clearlake needs to protect its natural resources and open space through policies that protect these resources and encourage smarter growth. This document will be essential when analyzing the environmental impact of this document to the agricultural and biological resources.

California Department of Conservation (2013). The Land Conservation (Williamson) Act. Retrieved from http://www.conservation.ca.gov/dlrp/lca/Pages/Index.aspx

Overview of the California Land Conservation Act of 1965, which protects agricultural and open space uses through lower property tax in exchange for a contract that restricts the uses of the land. This Act is an important tool for preservation of agricultural and open space.

California Department of Fish and Wildlife (2013). Vegetation habitats for Clearlake, CA [November 2, 2013]. Biogeographic Information and Observation System. Retrieved from http://imaps.dfg.ca.gov/viewers/biospublic/app.asp?zoomtoBookmark=3679

Provides information on vegetation habitats in Clearlake, CA. The data is compiled through surveys and several resources on natural habitats. The findings include a list of the habitats in Clearlake and its surroundings. This information is important for the existing conditions section and for analyzing the impact of growth in environmentally sensitive habitats.

California Department of Fish and Wildlife (2013). California Endangered Species Act. Retrieved from http://www.dfg.ca.gov/habcon/cesa/

An overview of the California Endangered Species Act. This Act is relevant to biological resources, because it serves to protect native plants, animals and their habitats.

California Native Plant Society (2013). The California rare plant ranking system. Retrieved from http://www.cnps.org/cnps/rareplants/ranking.php

Lists of rare plants and the locations where these species are found. The data is a compilation of several resources including plant surveys. The findings show a list of the different plants found in the Clearlake region and their status according to the California Native Plant Society's ranking system. This source will be useful for identifying the biological plant resources and their status. 
County of Lake Department (2011). Ordinance Code of the county of Lake, California. Retrieved from http://library.municode.com/index.aspx?clientID=16438\&stateID=5\&statename=California

This provides the Ordinance Code for the County of Lake, California. This document contains a legal framework for the County and some of the codes relate to agricultural and/or biological resources.

Fulton, William B. (1999). Guide to California Planning. Point Arena, CA: Solano Press books.

This book is a comprehensive guide for planning in the state of California. This book is relevant for its section explaining the CEQA process in California and especially on Environmental Impact Reports.

Governor's Office of Planning and Research (2012). State clearinghouse handbook 2012. Sacramento, CA: State Clearinghouse.

This guidebook summarizes the CEQA process and sample forms.

PBS\&J (March 3, 2009). Sacramento 2030 General Plan Master Environmental Impact Report City Project \#M04-031, State Clearinghouse No.2007072024. Retrieved from http://www.sacgp.org/mastereir/documents/Part1 GPMasterEIR.pdf

Environmental Impact Report on Sacramento's General Plan update. The file has several research methods depending on the section, including surveys and secondary sources. The findings for this document helped advice the City of Sacramento to whether to adopt this General Plan update. This document provides a good example of an EIR and how an analysis on a General Plan update can have different elements.

State of California, Resources Agency (October 23, 2009). CEQA guidelines amendments. Appendix G. Retrieved from http://ceres.ca.gov/ceqa/docs/Adopted_and_Transmitted_Text_of_SB97_CEQA_Guidelines_Ame ndments.pdf

The CEQA Guidelines interprets the California Environmental Quality Act and Appendix G in particular outlines the method to analyze items for environmental impact reports. The guideline is a straightforward outline of the best methods to follow CEQA. The Environmental Impact Report is required through CEQA, so this document is important in following the needed steps to complete the EIR.

State of California, Resources Agency, Department of Fish and Game, A guide to wildlife habitats of California, annual grasslands, http://www.dfg.ca.gov/biogeodata/cwhr/pdfs/AGS.pdf

The California Department of Fish and Game defines what annual grassland is and describes the different vegetation present in this ecosystem. This information assists with the biological section of the EIR.

State of California, Resources Agency, Department of Fish and Game, A guide to wildlife habitats of California, lacustrine, http://www.dfg.ca.gov/biogeodata/cwhr/pdfs/LAC.pdf

The California Department of Fish and Game defines a lacustrine habitat and describes the different vegetation present in this ecosystem. This information assists with the biological section of the EIR. 
State of California Water Resources Control Board (2013). Porter-Cologne Water Quality Control Act. Retrieved from http://www.swrcb.ca.gov/laws_regulations/docs/portercologne.pdf

A comprehensive description of the Porter-Cologne Water Quality Control Act written by the State of California Water Resources Control Board. The Water Quality Act is relevant to the EIR, because of the ecological setting of the City of Clearlake near the lake and its impact on its biological resources.

The Planning Center (August 13, 2013). Newark General Plan Tune Up Draft EIR for the City of Newark: State Clearinghouse No.2013012052. Retrieved from http://www.newark.org/images/uploads/comdev/pdfs/GeneralPlan/NewarkGP DEIR PublicRevie w.pdf

Environmental Impact Report on Newark's General Plan update. The file has several research methods depending on the section, including surveys and secondary sources. The findings for this document helped advice the City of Newark to whether to adopt this General Plan update. This document provides a good example of an EIR and how an analysis on a General Plan update can have different elements.

United States Department of Agriculture, Natural Resources Conservation Service. National soil survey handbook, title 430-VI. Retrieved from http://soils.usda.gov/technical/handbook/

The USDA creates a standard for soils and this handbook defines these standards. The USDA does surveys of the soils and has extensive data to back up their research. The document includes the different levels of prime farmland and its definitions. This document helps define agricultural resources for the analysis of the soil.

United States Department of Agriculture, Natural Resources Conservation Service (2013). Soil types for Clearlake, CA [October 30, 2013]. Web Soil Survey. Retrieved from http://websoilsurvey.sc.egov.usda.gov/App/WebSoilSurvey.aspx

Visually displays the different soil types for the Clearlake sphere of influence. The types of soil impact the local agricultural and biological resources.

United States Department of Interior, Fish and Wildlife Service (2013). Endangered Species Act. Retrieved from http://www.fws.gov/endangered/laws-policies/

Overview of the Endangered Species Act, which protects species in danger of extinction. This Act is an important tool for preservation species through protecting habitats with endangered species.

United States Department of Interior, Fish and Wildlife Service (2013). Permits - Bald and golden eagle protection act summaries. Retrieved from http://www.fws.gov/migratorybirds/mbpermits/ActSummaries.html

Overview of the Migratory Bird Treaty Act, which protects selected migratory bird species. This international act impacts the City of Clearlake, since unlawful taking of any migratory birds, or any part of such bird, without a permit is considered illegal. This means that the protection may extend to habitats that help support migratory birds, such as Clear Lake.

United States Environmental Protection Agency (2013). Clean Water Act, Section 404. Retrieved from http://water.epa.gov/lawsregs/guidance/wetlands/sec404.cfm 
Details the Clean Water Act section 404. This section requires that a permit is needed for any discharge or dredge into navigable waters. Since the City of Clearlake is located near a large body of water, this Act is especially relevant to the City. 


\section{Appendix B: Draft Environmental Impact Report}

\section{2 AGRICULTURAL RESOURCES}

This chapter describes Clearlake's existing environmental and regulatory setting with regards to agricultural resources and examines the impacts associated with adoption of the proposed General Plan on agricultural resources. The proposed Clear Lake General Plan may lead to changes in land use that could potentially cause impacts to this resource. The purpose of this analysis is to identify all of the potential agricultural impacts, and determine if they should be considered significant impacts on the environment.

\subsubsection{ENVIRONMENTAL SETTING}

\subsubsection{REGULATORY FRAMEWORK}

This section summarizes the federal, State, and local regulations that protect and manage agricultural resources in Clearlake.

Federal and State Laws

Farmland Protection Policy Act

The Natural Resources Conservation Service (NRCS) is primarily responsible for implementing the Farmland Protection Policy Act (FPPA). The purpose of the FPPA is to minimize the contribution of federal programs to conversion of farmland to nonagricultural uses by ensuring that federal programs are administered in a manner that is compatible with state, local, and private programs designed to protect farmland. For the purpose of FPPA, farmland includes prime farmland, unique farmland, and land of statewide or local importance. Farmland subject to FPPA requirements does not have to be currently used for cropland, but may include forestland, pastureland, or land for other uses. NRCS provides technical assistance to federal agencies, state and local governments, tribes, or nonprofit organizations that desire farmland protection programs or policies development. In addition to the Farmland Protection Program, the FPPA created the Land Evaluation and Site Assessment (LESA) program.

\section{Farm and Ranch Land Protection Program}

NRCS manages the Farm and Ranch Land Protection Program (FRPP), which is a voluntary program that aims to keep productive farmland in agricultural use. The program provides matching funds to 
state, local, or tribal government entities and nonprofit organizations with existing farmland protection programs to help purchase development rights to keep productive farm and ranchland in agricultural uses. The NRCS may pay up to 50 percent of the appraised fair market value of the easement. A minimum of 30 years is required for conservation easements and priority is given to applications with perpetual easements.

\section{Land Evaluation and Site Assessment}

The Land Evaluation and Site Assessment (LESA) system ranks lands for suitability and inclusion in the FPP. The site assessment is based mainly on non-soil factors related to agricultural use, developmental pressures and other public values of the site. These factors are used to numerically rank the suitability of parcels (USDA Natural Resources Conservation Service, n.d.).

The California LESA Model provides lead agencies with a methodology to ensure that potentially significant effects on the environment of agricultural land conversions are quantitatively and consistently considered. The model ranks the relative importance of farmland and the potential significance of its conversion on a site-by-site basis. The California LESA model includes these factors: land capability, surrounding agricultural lands, water availability, land uses within 1/4 mile, and protected resource lands.

\section{Senate Bill 1142- The California Farmland Conservancy Program Act}

The California Farmland Conservancy Program Act establishes a program for grants, to obtain agricultural conservation easements or fee title, from the Department of Conservation. The act creates the California Farmland Conservancy Program Fund and allows the Director of Conservation to make grants from a source other than the fund.

\section{The Williamson Act}

The California Land Conservation Act of 1965, known as the Williamson Act, is an agricultural and open space preservation program that offers landowners reduced property taxes for voluntarily restricting their land to agricultural and compatible open-space uses. The Williamson Act's goals are to protect agricultural resources, to preserve open space lands, and to promote efficient urban growth patterns. Williamson Act contract is a 10 year commitment and is automatically extended each year unless notice of cancellation or nonrenewal is given. The contract gives the landowner lower property tax assessments 
based on the agricultural land value rather than full market value.

\section{California Code of Regulations (Title 3. Food and Agriculture)}

The California Code of Regulations (CCR) Title 3, regulates the registration, management, use, and application of pesticides on agricultural lands. These regulations are enforced by the Lake County Agricultural Commissioner's Office. Section 6614 of the CCR requires that non-target crops, animals, or public or private property shall not be damaged by pesticide application.

\section{California Department of Conservation Farmland Classifications}

The California Department of Conservation (CDC) Farmland Mapping and Monitoring Program (FMMP) combines technical soils ratings and current land use information to create an inventory of different types of farm lands. The CDC divides Important Farmland into 7 categories:

- Prime Farmland is the best combination of physical and chemical characteristics for the growth of crops. The best possible condition in the soil quality, growing season, and moisture level provide the environment for sustained high yield crops. This category exempts lands that have been out of production for more than 2 mapping update cycles, or publicly owned lands that may not be used for agricultural purposes.

- Farmland of Statewide Importance is land other than Prime Farmland with good physical and chemical characteristics for the growth of crops. The previous stated exemptions apply to this category.

- Unique Farmland is land that doesn't meet the previous two categories' standards, but produces high-economic value crops. Publicly owned land with policy preventing agricultural use is again exempt from this category.

- Farmland of Local Importance is defined as land other than Prime Farmland, Farmland of Statewide Importance or Unique Farmland, which produces crops that are important to the local economy.

- Grazing Land is land suitable for grazing or browsing for livestock. The minimum mapping unit is 40 units. 
- Urban and Built-up Land is land with primarily man-made structures and landscapes. Minimum building density is at least 1 unit to 1.5 acres.

- Other Land refers to lands that do not fit into the previous categories. These lands may be characterized by: low density development, confined livestock facilities, or lands not suitable for livestock grazing due to geologic features.

\section{California Capability Rating}

Soil capability rating is a method for classifying soil quality provided by the Natural Resources Conservation Service (NRCS). Capability ratings range from Roman numerals I through VIII, with the lower the number indicating higher quality. Class I and Class II soils indicate Prime Farmland.

\section{Clearlake City Zoning Ordinance}

Article 4 section 21-4 of the City Zoning Ordinance includes the Regulations for the Agricultural Preserve Zone. This Section describe zones for lands in agriculture preserve and for the conservation and protection of land capable of producing agricultural products.

\subsubsection{Existing Conditions}

\section{Agriculture}

The agriculture, forestry, and fishing sector accounts for 4 percent of total economic activities in Clearlake (U.S Census Bureau, 2010). 466 acres are considered active agricultural lands in the City, and the majority of these lands grow grapes and walnuts. Most of the active agricultural lands are on the east side of Clearlake (Clearlake General Plan Background Report, 2012).

Just outside of the City boundary are 41 parcels dedicated to agricultural preservation. The 41 parcels add up to a total of 3,021 acres (Clearlake General Plan Background Report, 2012). Map 4.2-1, Open Space Map, shows all the agricultural parcels within the City boundaries. The agricultural parcels are primarily located along the northern boundary of the City. 


\section{Map 4.2-1 Map of Open Space in Clearlake}

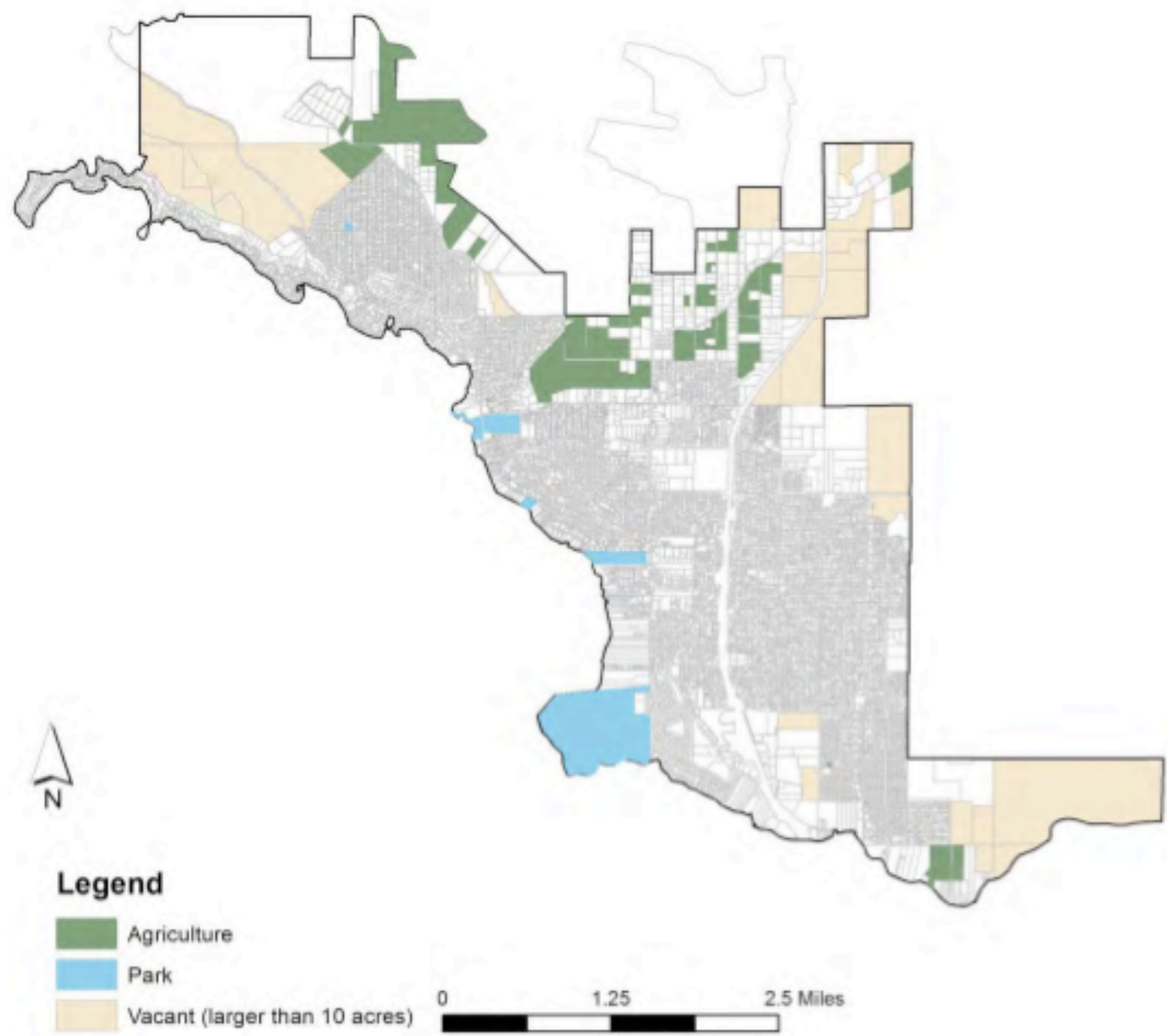

Map 4.2-2 shows all the lands under the Williamson Act in Lake County. Clearlake is mainly urban, but outside the City limits there are two major areas under the Williamson Act contract. These are located to the North and to the South East of the City. 


\section{Map 4.2-2 Lake County Williamson Act Fiscal Year 2012-13}

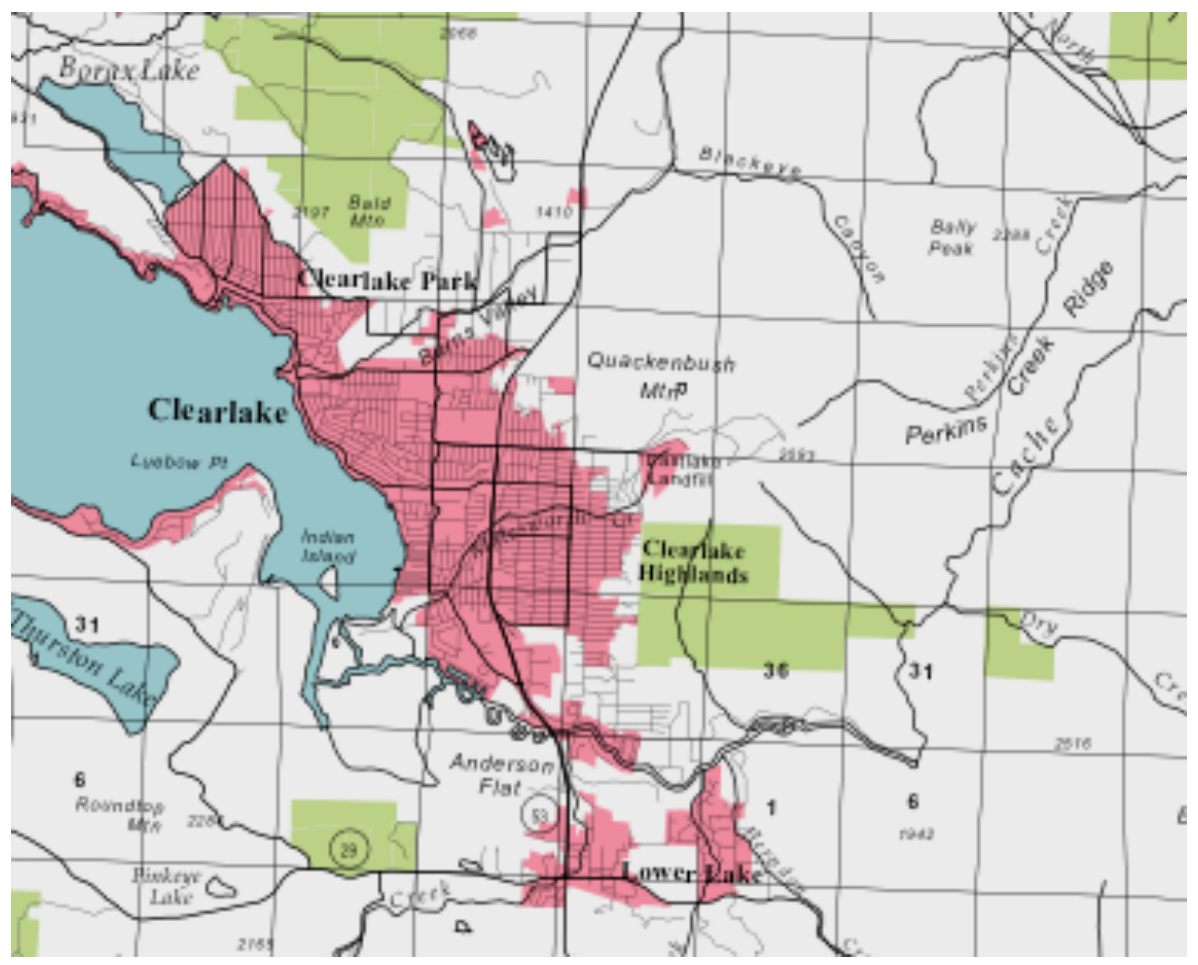

WILLIAMSON ACT- MIXED ENROLLMENT AGRICULTURAL LAND

Enrolled lands containing a combination of Prime, Non-Prime, Open Space Easement, or other contracted or enrolled lands not yet delineated by the county.

NON-WILLIAMSONACT LAND

\section{NON-ENROLLED LAND}

Land not enrolled in a Williamson Act contract and not mapped by Farmland Mapping \& Monitoring Program (FMMP) as Urban and Built-Up Land or Water.

\section{URBAN AND BUILT-UP LAND}

Urban and Built-Up Land is occupied by structures with a building density of at least lunit to 1.5 acres, or approximatley 6 structures to a 10 -acre parcel. Common examples include residential, industrial, commercial,
institutional facilities, cemeteries, airports, golf courses, sanitary landfills, sewage treatment, and water control institutional facilities, cemeteries, ant
structures. This definition and extent of mapping is derived from the latest Farmland Mapping and Monitoring Program Important Farmland Maps.

\section{WATER}

Perennial water bodies with an extent of at least 40 acres. This definition and extent of mapping is derived from the latest Farmland Mapping and Monitoring Program Important Farmland Maps.

Source: California Department of Conservation, 2013 


\section{Soil Types}

The City of Clearlake consists of hills and valleys, a geologic setting which typically indicates a variety of soil types. The soils on the hills are mainly shallow or moderately deep, medium-textured, and moderately well-drained to well-drained. The soils in the valleys and on low terraces are deep to very deep, medium-textured or fine-textured, and poorly-drained to well-drained (United States Department of Agriculture, 1989).

Appendix 4.2, and Map 4.2-3 show the type and location of soils found in the City. The dominant soil types in the City and surrounding sphere of influence are described by United States Department of Agriculture Soil Conservation Service as:

Bally-Phipps-Haploxeraifs association (30 to 75 percent slope)

- Very deep and well drained

- Slow permeability

- Rapid surface runoff

- Severe erosion hazard

- Uses: wildlife habitat and watershed

Maymen-Hopland-Mayacama association (50 to 75 percent slopes)

- Found on hills and mountains

- Shallow and excessively drained

- Moderate permeability

- Very rapid surface runoff

- Severe hazard of erosion

- Uses: wildlife habitat and watershed

Phillips Complex (30 to 50 percent slopes)

- Found on uplifted and dissected hills.

- Susceptible to slumping and gullying.

- Very deep and well drained

- Slow permeability

- Rapid surface runoff

- Moderate erosion hazard

- High shrink-swell potential

- Uses: livestock grazing, wildlife habitat, watershed, home site development and firewood production.

Clearlake has thirty-five types of soil (USDA, n.d.). In addition to the soil type, the range of slopes affects the utility of the land. The soil inventory shows that high slope percent, depth to bedrock, tendency to flood, poor soil strength and the shrinking and swelling of soils are all potential limiting factors. The majority of the soils within the City cannot absorb and filter septic tank effluent, so waste management is an important issue to consider in future development. Underneath several locations are loose sand and gravel or fractured bedrock, which can lead to groundwater contamination (Clearlake General Plan Background Report, 2012). 


\section{Map 4.2-3 Natural Resources Conservation Service Soil Delineations}

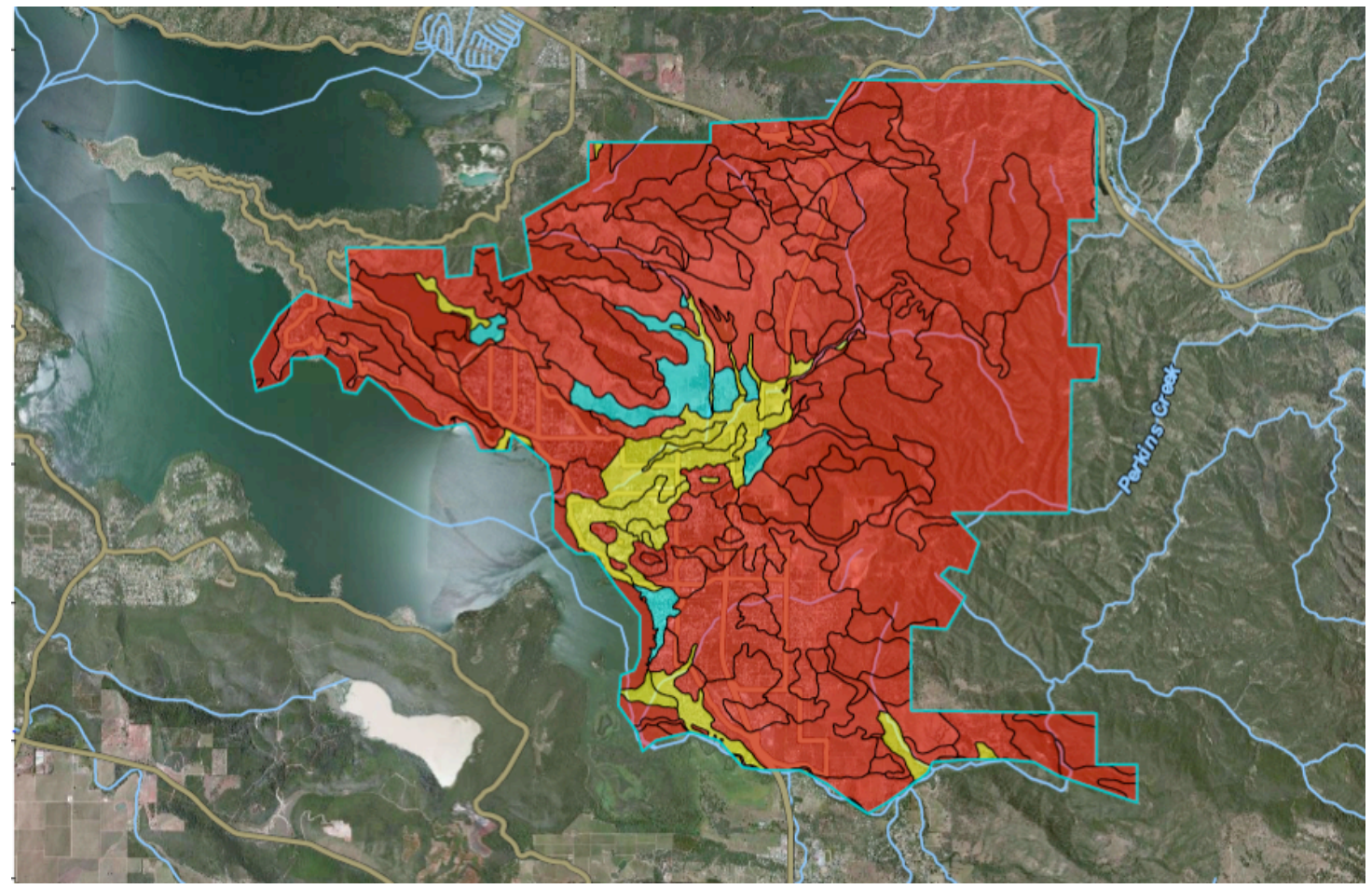

Source: United States Department of Agriculture Natural Resources Conservation Service Web soil survey, 2013

\section{MAP LEGEND}

\section{Area of Interest (AOI)}

Area of Interest (AOI)

Soils

Soil Rating Polygons

$\square$ Not prime farmland

All areas are prime farmland

Prime farmland if drained

Prime farmland if protected from flooding or not frequently flooded during the growing season

Prime farmland if irrigated
Prime farmland if drained and either protected from flooding or not frequently flooded during the growing season

Prime farmland if irrigated and drained

Prime farmland if irrigated and either protected from flooding or not frequently flooded during the growing season

Prime farmland if subsoiled, completely removing the root inhibiting soil layer
Prime farmland if irrigated and the product of I (soil erodibility) $\times \mathrm{C}$ (climate factor) does not exceed 60

Prime farmland if irrigated and reclaimed of excess salts and sodium

Farmland of statewide importance

Farmland of local importance

Farmland of unique importance

Not rated or not available 
Map 4.2-4 shows that Clearlake has no Prime Farmland or Farmland of Statewide Importance.

Unique Farmlands are located towards the outskirts of the City boundaries, especially in the Northern areas.

This figure also shows that Clearlake is surrounded by mostly grazing land to its east.

\section{Map 4.2-4 Important Farmland in Clearlake}

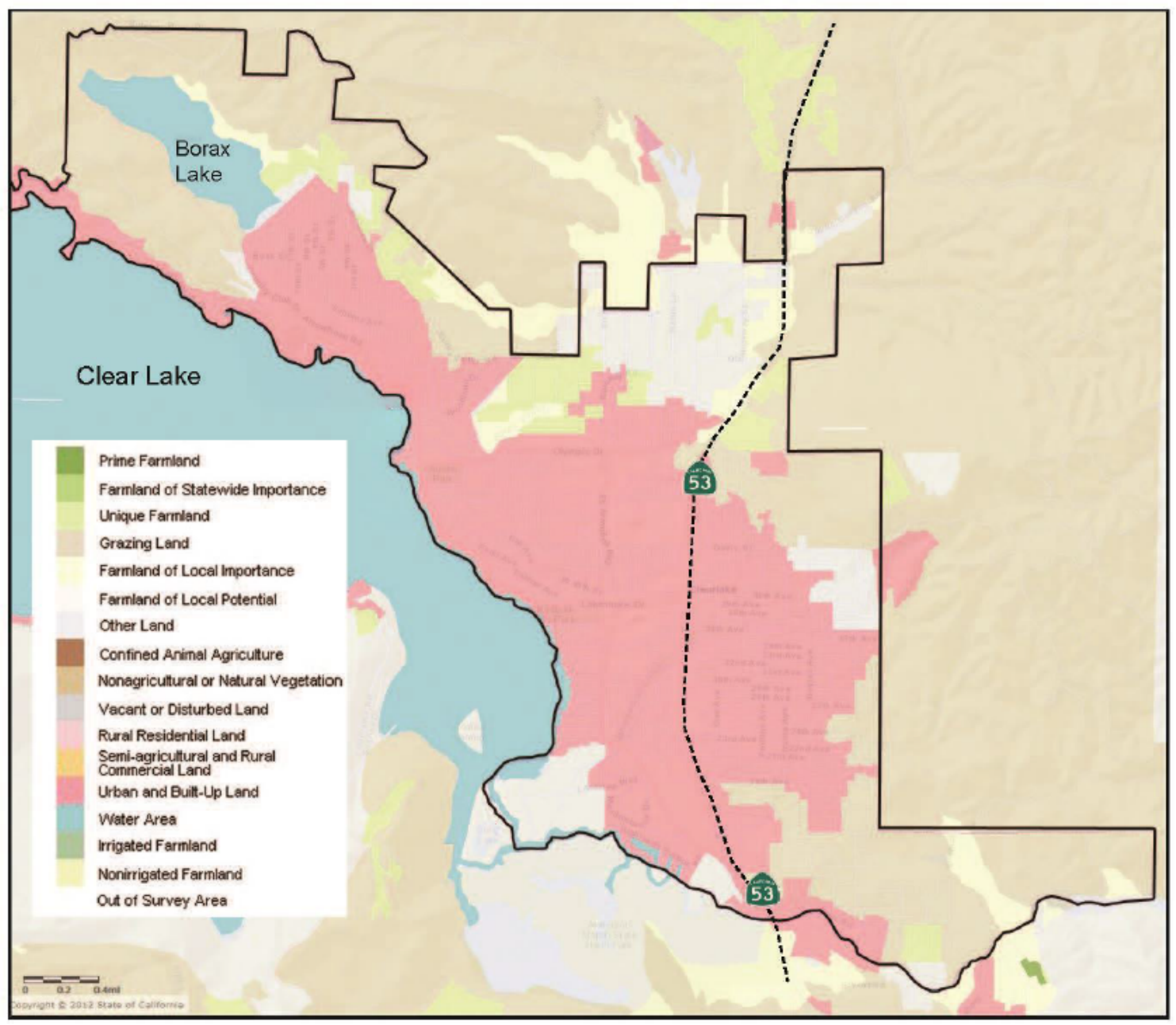

Source: Clearlake General Plan Background Report, 2012 


\subsubsection{STANDARDS OF SIGNIFICANCE}

\subsubsection{CEQA STANDARDS}

According to Appendix G of the CEQA Guidelines, the proposed Plan could have a significant effect on the environment with respect to agricultural resources if it would:

1. Convert Prime Farmland, Unique Farmland, or Farmland of Statewide Importance (Farmland), as shown on the maps prepared pursuant to the Farmland Mapping and Monitoring Program of the California Resources Agency, to non-agricultural use;

2. Conflict with existing zoning for agricultural use, or a Williamson Act contract;

3. Conflict with existing zoning for, or cause rezoning of, forest land (as defined in Public Resources Code section 12220(g)), timberland (as defined by Public Resources Code section 4526), or timberland zoned Timberland Production (as defined by Government Code section 51104(g));

4. Result in the loss of forest land or conversion of forest land to non-forest use; or

5. Involve other changes in the existing environment which, due to their location or nature, could result in conversion of Farmland, to non-agricultural use or conversion of forest land to non-forest use.

\subsubsection{METHODOLOGY}

The analysis of potential cumulative impacts on agricultural resources that could result from adoption of the proposed General Plan 2040 was based on review of the proposed General Plan 2040 Background Report; the California Department of Conservation 2006-2008 Regional and Statewide Conversion Summary and Farmland Conversion Report; the United States Department of Agriculture's resources; the California Department of Conservation's resources; and the Farmland Mapping and Monitoring Program (FMMP). The proposed project was then compared to the existing conditions to determine the potential impacts due to loss of agricultural resources. Existing state and local regulations and policies related to agricultural resources were also accounted for during the analysis. The CEQA standards of significance from the CEQA Guidelines were adjusted to apply to the City of Clearlake. Agricultural Resources' Standard of Significance from Appendix G refer to forest land and timberland, but 
examination of the City's sphere of influence showed no presence of forest land or timberland. Therefore, the standard of significance three and four were not applied. Standard of significance five was adjusted to apply to only agricultural lands as seen in impact AG-3.

\subsubsection{IMPACT DISCUSSION}

This section discusses the Plan-specific and cumulative impacts related to agricultural resources. This discussion is organized by and responds to each of the potential impacts identified in the Standards of Significance.

AG-1 Build-out of the proposed plan would result in less-than-significant impacts in regards to the conversion of Prime Farmland, Farmland of Statewide Importance or Unique Farmlands to non-agricultural use.

According to the California Important Farmland Finder and the 2010 FMMP, there are no Prime Farmland or Farmland of Statewide Importance classified land located within the City's sphere of influence. There are Unique Farmlands existing within the City's boundary and in the City's sphere of influence. Map 4.2-4 shows the location of Unique Farmlands as outside of the central urban areas where most of the new growth is proposed. The Preferred Growth Scenario Conceptual Land Use Map in the City's General Plan Update shows that the growth is concentrated in existing built space and agricultural lands are left to existing uses.

Goals, policies and programs in the City's 2040 General Plan Update further promote the continued productivity and preservation of existing agricultural lands. One of the key policies include, Policy CO 5.1.2, which states that the City shall discourage conversion of agricultural land into nonagricultural uses.

The proposed 2040 General Plan Update helps minimize the conversion of agricultural lands outside the City limits by accommodating future development within the City boundaries. The projected growth would be focused within the City's urbanized sections, so the impact on agricultural resources and operations, if any, would be less than significant. 
Further, the proposed Plan includes policies and actions that would also protect Prime Farmland,

Farmland of Statewide Importance and Unique Farmland from conversion into non-agricultural use. These proposed policies and programs include:

Program CO 2.2.2.1

Develop a marketing campaign to promote the viticulture industry as beneficial to economic development and water conservation.

Program CO 5.1.1.1

Create development standards for properties within land zoned agricultural.

Program CO 5.1.1.2

Create monitoring program to enforce agricultural land development standards.

Policy CO 5.1.2

The City shall discourage conversion of agricultural land into non-agricultural uses.

Program CO 5.1.2.1

Establish a reserve fund to acquire fee simple or easements of agricultural properties threatened for conversion to other uses.

Program OS 6.2.1.2

Use conservation design, unit clustering and infill, and non---traditional housing development pattern in order to prevent new housing from encroaching on preserved and open space areas, including forested land, fields, habitat corridors, and wetlands.

Applicable Federal, State and local regulations, together with the proposed Plan's policies and programs would reduce potential impact to the existing Unique Farmland. Therefore, impacts from the proposed Plan would be less-than-significant.

\section{Applicable Regulations:}

Farmland Protection Policy Act

Farm and Ranch Land Protection Program

Senate Bill 1142- The California Farmland Conservancy Program Act

California Code of Regulations (Title 3. Food and Agriculture)

City Zoning Ordinance, Article 4 section 21-4

Significance Before Mitigation: Less than significant. 


\section{AG-2}

Build-out of the proposed plan would not conflict with existing zoning for agricultural use, or with a Williamson Act contract.

According to the Cal Poly Land Use Inventory (2012), the City contains 465.7 acres agricultural land. The existing land use zoning as seen in the Clearlake Zoning Map, Map 4.2-5, shows that none of the agricultural zones conflict with the proposed land use changes. In the map agricultural zoning is indicated with as "A" and is seen only in the Southern part of the City. No growth or changes are proposed in this area.

Map 4.2-2 shows the location of land under Williamson Act contract. There is no land under Williamson Act in the City limits, but there are some Williamson Act land located within the sphere of influence. The lands under Williamson Act are located outside of the Plan's proposed growth areas, so these lands would not be affected by the proposed Plan.

The proposed General Plan includes policies to preserve existing agricultural resources, such as Policy CO 5.1.2 that aims to maintain agricultural lands as their existing use. Additionally, any changes to the City's Zoning Code would require the City's approval and would need to comply with existing regulations and laws.

Besides limiting new development in non-agricultural areas, the proposed General Plan policies and existing zoning regulations would ensure that agricultural land uses would be protected. This impact is considered less than significant.

Further, the proposed Plan includes policies and programs that would also protect agricultural resources and land under Williamson Act from potential zone changes. These proposed policies and programs include:

Program CO 5.1.1.1

Create development standards for properties within land zoned agricultural.

Policy CO 5.1.2

The City shall discourage conversion of agricultural land into non-agricultural uses.

Program CO 5.1.2.1

Establish a reserve fund to acquire fee simple or easements of agricultural properties threatened for conversion to other uses. 


\section{Map 4.2-5 Clearlake Zoning Map}

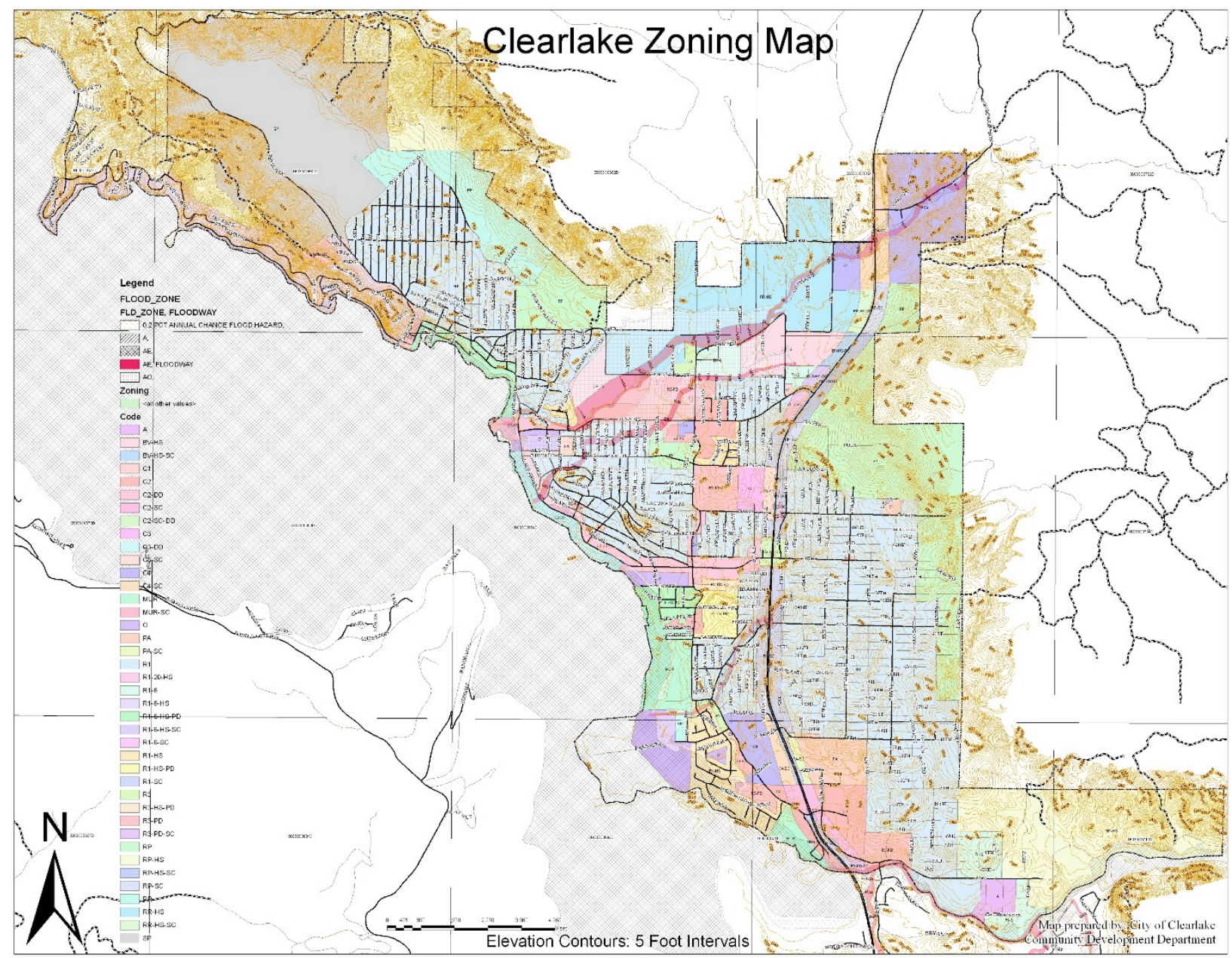

Source: City of Clearlake Community Development Department

Program OS 6.2.1.2

Use conservation design, unit clustering and infill, and non-traditional housing development pattern in order to prevent new housing from encroaching on preserved and open space areas, including forested land, fields, habitat corridors, and wetlands.

Applicable Federal, State and local regulations, together with the proposed Plan's policies and programs would reduce potential impact to the land under Williamson Act contract. Therefore, impacts from the proposed Plan would be less-than-significant.

\section{Applicable Regulations:}

Farmland Protection Policy Act

Farm and Ranch Land Protection Program 
Senate Bill 1142- The California Farmland Conservancy Program Act

California Code of Regulations (Title 3. Food and Agriculture)

City Zoning Ordinance, Article 4 section 21-4

The California Land Conservation Act of 1965

Significance Before Mitigation: Less than significant.

AG-3 Build-out of the proposed plan would result in less-than-significant impacts in converting lands adjacent to agricultural lands into incompatible uses.

According to the Preferred Growth Scenario Conceptual Land Use Map and the existing Land Use Map contained in the City of Clearlake 2040 General Plan Update and Background Report, the agricultural lands within the City are mainly located in the Northern section of the City. These existing agricultural lands are already surrounded by public facilities, residential and commercial uses. The proposed Plan could increase commercial uses and attract higher density residential uses around the agricultural lands.

The proposed Plan could adversely affect adjacent agricultural operations and, in turn, agricultural operations may adversely affect new developments. The proposed growth next to agricultural resources may result in conflicts from additional traffic, dust/odor/pesticide drift, or introduction of pests or domestic pets. These conflicts may require the adjacent farmer to adjust his operations. However, the proposed General Plan includes policies to protect existing agricultural operations, such as Program OS 6.2.1.2 which encourages the use of conservation design in order to protect open space and agricultural resources from development. Additionally, the California Code of Regulations (CCR) Title 3, sections 6000-6920 regulates the registration, management, use, and application of pesticides on agricultural lands, and includes provisions for the protection of persons, animals, and property. CCR Title 3, sections 3482.5 and 3482.6 protects the right-to-farm in California by establishing that agricultural operations that are in effect for more than three years and are conducted in accordance with accepted customs and standards shall not be considered a private or public nuisance due to any changes in condition or within the locality. Because proposed General Plan policies and existing zoning regulations would ensure that agricultural land uses would be protected from adjacent land uses, this impact is considered less than significant. The proposed 
Plan includes policies and programs that would also protect agricultural resources from adjacent land uses.

These proposed policies and programs include:

Program CO 5.1.1.1

Create development standards for properties within land zoned agricultural.

Policy CO 5.1.2

The City shall discourage conversion of agricultural land into non-agricultural uses.

Program CO 5.1.2.1

Establish a reserve fund to acquire fee simple or easements of agricultural properties threatened for conversion to other uses.

Program OS 6.2.1.2

Use conservation design, unit clustering and infill, and non-traditional housing development pattern in order to prevent new housing from encroaching on preserved and open space areas, including forested land, fields, habitat corridors, and wetlands.

Applicable Federal, State and local regulations, together with the proposed Plan's policies and programs would reduce potential impact to the land under Williamson Act contract. Therefore, impacts from the proposed Plan would be less-than-significant.

\section{Applicable Regulations:}

Farmland Protection Policy Act

Farm and Ranch Land Protection Program

Senate Bill 1142- The California Farmland Conservancy Program Act

California Code of Regulations (Title 3. Food and Agriculture)

City Zoning Ordinance, Article 4 section 21-4

Significance Before Mitigation: Less-than-significant.

\footnotetext{
AG-4 The proposed Plan would result in less-than-significant cumulative impacts related to agricultural resources.
}

According to the California Department of Conservation, Lake County's agricultural land acreage decreased from 2008 to 2010. Prime Farmland decreased by 2,033 acres, Farmland of Statewide Importance decreased by 252 acres, and Unique Farmland decreased by 689 acres in those two years. 
Farmland of local Importance, however, increased by 1,381 acres. If this trend continues into the future, this indicates the conversion of a large amount of agricultural lands in the County.

The California Important Farmland Finder and the 2010 FMMP reveal that there is no Prime Farmland or Farmland of Statewide Importance located within the City's sphere of influence. There are Unique Farmlands existing within the City's boundary and in the City's sphere of influence. Map 4.2-4 shows the location of Unique Farmlands as outside of the central urban areas where most of the new growth is proposed. Because the proposed Plan suggests key growth areas within existing built space, agricultural lands are essentially preserved. The proposed Plan may impact agricultural operations by changing the types of land uses adjacent to the agricultural lands. The CCR Title 3, sections 3482.5 and 3482.6 protects the right-to-farm in California and this State regulation helps mitigate this potential impact.

The implementation of the City of Clearlake's 2040 General Plan Update would focus future growth within the City's existing urban space, and the proposed Plan emphasizes the preservation of existing agricultural resources through its policies and programs. Additionally, the proposed Plan's development within the built environment would minimize the need for future development onto agricultural resources outside of the City's boundaries.

Relevant proposed policies and programs contained in the proposed Plan include:

Program CO 2.2.1.1

Develop a set of approved water conservation techniques and best management practices to guide streamlined approval of development projects.

Policy CO 2.2.2

Promote the conversion of water intensive agricultural practices to less intensive agricultural uses.

Program CO 2.2.2.1

Develop a marketing campaign to promote the viticulture industry as beneficial to economic development and water conservation.

Policy CO 5.1.1

Owners of agricultural land shall be required to meet development standards for agricultural zones.

Program CO 5.1.1.1

Create development standards for properties within land zoned agricultural.

Program CO 5.1.1.2

Create monitoring program to enforce agricultural land development standards. 
Policy CO 5.1.2

The City shall discourage conversion of agricultural land into non-agricultural uses.

Program CO 5.1.2.1

Establish a reserve fund to acquire fee simple or easements of agricultural properties threatened for conversion to other uses.

Program OS 6.2.1.2

Use conservation design, unit clustering and infill, and non-traditional housing development pattern in order to prevent new housing from encroaching on preserved and open space areas, including forested land, fields, habitat corridors, and wetlands.

Applicable Federal, State and local regulations, together with the proposed Plan's policies and programs would reduce potential impact to the land under Williamson Act contract. Therefore, impacts from the proposed Plan would be less-than-significant.

\section{Applicable Regulations:}

Farmland Protection Policy Act

Farm and Ranch Land Protection Program

Senate Bill 1142- The California Farmland Conservancy Program Act

California Code of Regulations (Title 3. Food and Agriculture)

City Zoning Ordinance, Article 4 section 21-4

The California Land Conservation Act of 1965

Significance Before Mitigation: Less-than-significant.

\subsubsection{SUMMARY OF SIGNIFICANT IMPACTS AND MITIGATION MEASURES}

The proposed Plan would not result in any significant Plan-level or cumulative impacts to agricultural resources and therefore no mitigation measures are required. 


\section{Agricultural Resources References}

California Department of Conservation. (2013). Farmland mapping and monitoring program, Important farmland data availability, Lake County 2008-2010 Land use Conversion, Table A-12. Retrieved from http://redirect.conservation.ca.gov/dlrp/fmmp/county_info_results.asp.

California Department of Conservation. (2013). The land conservation (williamson) act. Retrieved from http://www.conservation.ca.gov/dlrp/lca/Pages/Index.aspx.

California Department of Conservation. (2013). Important farmland mapping categories and soil taxonomy terms. Retrieved from http://www.conservation.ca.gov/dlrp/fmmp/Documents/soil_criteria.pdf.

California Department of Conservation. (2013). Important farmland finder. Retrieved from http://maps.conservation.ca.gov/ciff/ciff.html.

California Department of Pesticide Regulation. (2013). California code of regulations (Title 3. Food and Agriculture) Division 6. Pesticides and Pest Control Operations. Retrieved from http://www.cdpr.ca.gov/docs/legbills/calcode/chapter .htm.

City of Clearlake, CA. (2012). General plan background report. Prepared by California Polytechnic State University, San Luis Obispo.

City of Clearlake, CA. (2013). Draft 2040 General Plan. Prepared by California Polytechnic State University, San Luis Obispo.

Post Buckley Schuh \& Jernigan. (2009). Sacramento 2030 general plan master environmental impact report city project \#M04-031, State Clearinghouse No.2007072024. Retrieved from http://www.sacgp.org/master-eir/documents/Part1_GPMasterEIR.pdf.

State of California Department of Conservation. (2007). State mining and geology board. Retrieved from http://www.conservation.ca.gov/SMGB/Pages/Index.aspx.

State of California Department of Conservation. (2007). Surface Mining and Reclamation Act of 1975. Retrieved from http://www.conservation.ca.gov/omr/smara/Pages/index.aspx.

United States Census Bureau. (2010). DP03: Selected Economic Characteristics 2006-2010 American Community Survey. Retrieved from http://factfinder2.census.gov/faces/tableservices/jsf/pages/productview.xhtml?fpt=table.

United States Department of Agriculture, Soil Conservation Service. (1989). Soil survey of Lake County, California. Retrieved from http://soildatamart.nrcs.usda.gov/manuscripts/CA033/0/lake.pdf.

United States Department of Agriculture, Natural Resources Conservation Service. (2006). National soil survey handbook, Technical handbook part 622 interpretive groups. Retrieved from http://soils.usda.gov/technical/handbook/contents/part622.html.

United States Department of Agriculture Natural Resources Conservation Service. (1996). Soil quality resource concerns: soil erosion. Retrieved from http://soils.usda.gov/sqi/publications/files/sq_two_1.pdf.

United States Department of Agriculture Natural Resources Conservation Service. (n.d.). Web soil survey. Retrieved from http://websoilsurvey.nrcs.usda.gov/.

United States Environmental Protection Agency. (2012). Summary of the resource conservation and recovery act of 1976. Retrieved from http://www.epa.gov/lawsregs/laws/rcra.html. 
Appendix 4.2

Natural Resources Service Soils

\begin{tabular}{|c|c|c|c|}
\hline $\begin{array}{l}\text { Map } \\
\text { Unit } \\
\text { Symbo }\end{array}$ & Map Unit Name & $\begin{array}{l}\text { Acres } \\
\text { in AOI }\end{array}$ & $\begin{array}{l}\text { Percent } \\
\text { of AOI }\end{array}$ \\
\hline 103 & $\begin{array}{l}\text { Asbill clay loam, } 5 \text { to } 8 \\
\text { percent slopes }\end{array}$ & 486.3 & $2.70 \%$ \\
\hline 104 & $\begin{array}{l}\text { Asbill clay loam, } 8 \text { to } 15 \\
\text { percent slopes }\end{array}$ & 555.5 & $3.10 \%$ \\
\hline 107 & $\begin{array}{l}\text { Bally-Phipps complex, } 15 \text { to } \\
30 \text { percent slopes }\end{array}$ & 318.9 & $1.80 \%$ \\
\hline 108 & $\begin{array}{l}\text { Bally-Phipps-Haploxeraifs } \\
\text { association,30 to } 75 \text { percent } \\
\text { slopes }\end{array}$ & 2895.5 & $16.10 \%$ \\
\hline 114 & $\begin{array}{l}\text { Benridge-Sodabay loams, } 8 \text { to } \\
15 \text { percent slopes }\end{array}$ & 808 & $4.50 \%$ \\
\hline 116 & $\begin{array}{l}\text { Bressa-Milshoim loams, } 2 \text { to } \\
15 \text { percent slopes }\end{array}$ & 1.5 & $0 \%$ \\
\hline 119 & $\begin{array}{l}\text { Bressa-Milshoim loams, } 8 \text { to } \\
15 \text { percent slopes }\end{array}$ & 12.3 & $0.10 \%$ \\
\hline 120 & $\begin{array}{l}\text { Bressa-Milshoim loams, } 15 \text { to } \\
30 \text { percent slopes }\end{array}$ & 128.9 & $0.70 \%$ \\
\hline 121 & Clear Lake clay, drained, cool & 34.9 & $0.20 \%$ \\
\hline 122 & $\begin{array}{l}\text { Clear Lake Variant clay, } \\
\text { drained }\end{array}$ & 67.6 & $0.40 \%$ \\
\hline 124 & Cole variant clay loam & 225.6 & $1.30 \%$ \\
\hline 131 & $\begin{array}{l}\text { Fluvaquentic Haplaquolis, } \\
\text { nearly level }\end{array}$ & 80.1 & $0.40 \%$ \\
\hline 133 & $\begin{array}{l}\text { Forbesville loam, } 5 \text { to } 15 \\
\text { percent slopes }\end{array}$ & 23.4 & $0.10 \%$ \\
\hline 147 & Kelsey fine sandy loam & 2.8 & $0 \%$ \\
\hline 148 & $\begin{array}{l}\text { Kidd-Forward complex, } 5 \text { to } \\
30 \text { percent slopes }\end{array}$ & 522.4 & $2.90 \%$ \\
\hline 150 & $\begin{array}{l}\text { Kilaga variant loam, } 0 \text { to } 5 \\
\text { percent slopes }\end{array}$ & 12.8 & $0.10 \%$ \\
\hline
\end{tabular}

\begin{tabular}{|c|c|c|c|}
\hline 152 & $\begin{array}{l}\text { Konocti-Hambright complex, } \\
15 \text { to } 30 \text { percent slopes }\end{array}$ & 295.5 & $1.60 \%$ \\
\hline 152 & $\begin{array}{l}\text { Konocti-Hambright complex, } \\
5 \text { to } 15 \text { percent slopes }\end{array}$ & 43.3 & $0.20 \%$ \\
\hline 154 & $\begin{array}{l}\text { Konocti-Hambright-Rock } \\
\text { outcrop complex, } 30 \text { to } 75 \\
\text { percent slopes }\end{array}$ & 58.3 & $0.30 \%$ \\
\hline 156 & $\begin{array}{l}\text { Konocti-Hambright-Rock } \\
\text { outcrop complex, } 15 \text { to } 30 \\
\text { percent slopes }\end{array}$ & 198.5 & $1.10 \%$ \\
\hline 158 & Lupoyoma silt loam, protected & 297.4 & $1.60 \%$ \\
\hline 159 & $\begin{array}{l}\text { Manzanita loam, } 2 \text { to } 5 \\
\text { percent slopes }\end{array}$ & 108.1 & $0.60 \%$ \\
\hline 160 & $\begin{array}{l}\text { Manzanita loam, } 5 \text { to } 15 \\
\text { percent slopes }\end{array}$ & 125.4 & $0.70 \%$ \\
\hline 161 & $\begin{array}{l}\text { Manzanita loam, } 15 \text { to } 25 \\
\text { percent slopes }\end{array}$ & 15.5 & $0.10 \%$ \\
\hline 162 & $\begin{array}{l}\text { Manzanita loam, } 2 \text { to } 8 \\
\text { percent slopes }\end{array}$ & 182.6 & $1 \%$ \\
\hline 163 & $\begin{array}{l}\text { Manzanita loam, } 8 \text { to } 25 \\
\text { percent slopes }\end{array}$ & 247.4 & $1.40 \%$ \\
\hline 167 & $\begin{array}{l}\text { Maymen-Etsel-Mayacama } \\
\text { complex, } 30 \text { to } 75 \text { percent } \\
\text { slopes }\end{array}$ & 153 & $0.80 \%$ \\
\hline 168 & $\begin{array}{l}\text { Maymen-Etsel-Snook } \\
\text { complex, } 15 \text { to } 50 \text { percent } \\
\text { slopes }\end{array}$ & 511 & $2.80 \%$ \\
\hline 169 & $\begin{array}{l}\text { Maymen-Etsel-Snook } \\
\text { complex, } 30 \text { to } 75 \text { percent } \\
\text { slopes }\end{array}$ & 16.8 & $0.10 \%$ \\
\hline 171 & $\begin{array}{l}\text { Maymen-Hopland-Etsel } \\
\text { association, } 15 \text { to } 50 \text { percent } \\
\text { slopes }\end{array}$ & 160.3 & $0.90 \%$ \\
\hline 173 & $\begin{array}{l}\text { Maymen-Hopland-Mayacama } \\
\text { association, } 30 \text { to } 50 \text { percent }\end{array}$ & 151.1 & $0.80 \%$ \\
\hline
\end{tabular}




\begin{tabular}{|c|c|c|c|}
\hline & slopes & & \\
\hline 174 & $\begin{array}{l}\text { Maymen-Hopland-Mayacama } \\
\text { association, } 50 \text { to } 75 \text { percent } \\
\text { slopes }\end{array}$ & 1138.3 & $6.30 \%$ \\
\hline 175 & $\begin{array}{l}\text { Maymen-Milsholm-Bressa } \\
\text { complex, } 30 \text { to } 50 \text { percent } \\
\text { slopes }\end{array}$ & 260.3 & $1.40 \%$ \\
\hline 177 & $\begin{array}{l}\text { Maymen-Bressa loams, } 30 \text { to } \\
50 \text { percent slopes }\end{array}$ & 65.7 & $0.40 \%$ \\
\hline 178 & $\begin{array}{l}\text { Maymen-Bressa -Hopland } \\
\text { association, } 30 \text { to } 50 \text { percent } \\
\text { slopes }\end{array}$ & 448.8 & $2.50 \%$ \\
\hline 182 & $\begin{array}{l}\text { Neice-Sobrante-Hambright } \\
\text { complex, } 30 \text { to } 75 \text { percent } \\
\text { slopes }\end{array}$ & 928.1 & $5.10 \%$ \\
\hline 195 & $\begin{array}{l}\text { Phipps complex, } 5 \text { to } 15 \\
\text { percent slopes }\end{array}$ & 525.2 & $2.90 \%$ \\
\hline 196 & $\begin{array}{l}\text { Phipps complex,30 to } 50 \\
\text { percent slopes }\end{array}$ & 2345.3 & $13 \%$ \\
\hline 197 & $\begin{array}{l}\text { Pomo-Bressa loams, } 15 \text { to } 50 \\
\text { percent slopes }\end{array}$ & 105.4 & $0.60 \%$ \\
\hline 199 & Riverwash & 2.7 & $0.00 \%$ \\
\hline 203 & $\begin{array}{l}\text { San Joaquin variant fine sandy } \\
\text { loam, } 0 \text { to } 5 \text { percent slopes }\end{array}$ & 53.2 & $0.30 \%$ \\
\hline 208 & $\begin{array}{l}\text { Skyhight-Asbill complex, } 15 \\
\text { to } 50 \text { percent slopes }\end{array}$ & 12 & $0.10 \%$ \\
\hline 209 & $\begin{array}{l}\text { Skyhigh-Milsholm loams, } 15 \\
\text { to } 50 \text { percent slopes }\end{array}$ & 713.5 & $4 \%$ \\
\hline 210 & $\begin{array}{l}\text { Skyhigh-Sleeper-Milsholm } \\
\text { association, } 8 \text { to } 15 \text { percent } \\
\text { slopes }\end{array}$ & 49.3 & $0.30 \%$ \\
\hline 211 & $\begin{array}{l}\text { Skyhigh-Sleeper-Milsholm } \\
\text { association, } 15 \text { to } 30 \text { percent } \\
\text { slopes }\end{array}$ & 119.7 & $0.70 \%$ \\
\hline 212 & $\begin{array}{l}\text { Skyhigh-Sleeper-Milsholm } \\
\text { association, } 30 \text { to } 50 \text { percent }\end{array}$ & 134.8 & $0.70 \%$ \\
\hline
\end{tabular}

\begin{tabular}{|c|c|c|c|}
\hline & slopes & & \\
\hline 215 & $\begin{array}{l}\text { Sleeper variant-Sleeper loams, } \\
30 \text { to } 50 \text { percent slopes }\end{array}$ & 55.9 & $0.30 \%$ \\
\hline 218 & $\begin{array}{l}\text { Sobrante-Guenoc-Hambright } \\
\text { complex, } 2 \text { to } 15 \text { percent } \\
\text { slopes }\end{array}$ & 122.1 & $0.70 \%$ \\
\hline 219 & $\begin{array}{l}\text { Sobrante-Guenoc-Hambright } \\
\text { complex, } 15 \text { to } 30 \text { percent } \\
\text { slopes }\end{array}$ & 296.3 & $1.60 \%$ \\
\hline 220 & $\begin{array}{l}\text { Sobrante-Guenoc-Hambright } \\
\text { complex, } 30 \text { to } 50 \text { percent } \\
\text { slopes }\end{array}$ & 162.9 & $0.90 \%$ \\
\hline 232 & Still loam & 125.4 & $0.70 \%$ \\
\hline 233 & $\begin{array}{l}\text { Still loam, stratified } \\
\text { substratum }\end{array}$ & 63.6 & $0.40 \%$ \\
\hline 234 & Still gravelly loam & 186.9 & $1 \%$ \\
\hline 236 & $\begin{array}{l}\text { Stonyford-Guenoc complex, } \\
30 \text { to } 50 \text { percent slopes }\end{array}$ & 36.6 & $0.20 \%$ \\
\hline 237 & $\begin{array}{l}\text { Talmage very gravelly sandy } \\
\text { loam }\end{array}$ & 14.8 & $0.10 \%$ \\
\hline 241 & $\begin{array}{l}\text { Vitrandepts-Cinderland } \\
\text { complex, } 15 \text { to } 75 \text { perent } \\
\text { slopes }\end{array}$ & 21.8 & $0.10 \%$ \\
\hline 242 & $\begin{array}{l}\text { Wappo loam, } 2 \text { to } 8 \text { percent } \\
\text { slopes }\end{array}$ & 72.2 & $0.40 \%$ \\
\hline 244 & $\begin{array}{l}\text { Wappo variant clay loam, } 2 \text { to } \\
8 \text { percent slopes }\end{array}$ & 34.6 & $0.20 \%$ \\
\hline 246 & Wolfcreek gravely loam & 55.2 & $0.30 \%$ \\
\hline 247 & Wolfcreek loam & 144.7 & $0.80 \%$ \\
\hline 249 & $\begin{array}{l}\text { Xerofluvents-Riverwash } \\
\text { comples }\end{array}$ & 26.8 & $0.10 \%$ \\
\hline \multirow[t]{2}{*}{256} & Water & 570.5 & $3.20 \%$ \\
\hline & Total & 18033.7 & $100 \%$ \\
\hline
\end{tabular}




\subsection{BIOLOGICAL RESOURCES}

This chapter describes Clearlake's existing environmental and regulatory setting with regards to biological resources and examines the biological resources impacts associated with adoption of the proposed General Plan. The proposed may lead to changes in land use that could potentially cause impacts to biological resources. The purpose of this analysis is to identify all of the potential impacts on biological resources, and determine if they should be considered significant impacts on the environment.

\subsubsection{ENVIRONMENTAL SETTING}

\subsubsection{REGULATORY FRAMEWORK}

This section discusses State, federal, and local regulations and programs related to biological resources.

Federal and State Laws

Federal Endangered Species Act

The Federal Endangered Species Act (FESA) protects fish and wildlife species that are listed as threatened or endangered, as well as their habitats. FESA (16 U.S.C. Section 1531 et seq.) is implemented by the Department of Interior's U.S. Fish and Wildlife Service (USFWS) and National Oceanic and Atmospheric Administration, National Marine Fisheries Service (NOAA Fisheries). "Endangered" species are those that are in danger of extinction in a significant portion of their range, and "threatened" species are those likely to become endangered in the near future.

Section 7 of the FESA mandates that all federal agencies consult with USFWS and NOAA Fisheries if a proposed project may affect a listed species or its habitat. This applies to any lands not just federal lands.

Section 9 of the FESA prohibits the take of any fish or wildlife species listed as endangered; this also applies to the habitat the fish or wildlife species may inhabit. Take is defined as an action or attempt to hunt, harm, harass, pursue, shoot, wound, capture, kill, trap, or collect a species. Endangered plant species are also protected under this Section. 


\section{Federal Clean Water Act}

The Federal Clean Water Act (FCWA) is administered by the Environmental Protection Agency (EPA) and the U.S. Army Corps of Engineers (Corps). The Corps regulates the discharge of fill material into United States' waterways, including lakes, rivers, streams and their tributaries, as well as wetlands. Section 404 (Discharges of Dredge or Fill Material) requires that project proponents obtain a permit from the Corps for all discharges of dredged or fill material into waters of the United States before proceeding with a proposed action. Corps permits must then be certified by the State Water Resources Control Board. Section 401 (Certification) lists additional requirements for permit review. Certification from the California Regional Water Quality Control Board is also required when a proposed activity may result in discharge into navigable waters.

Migratory Bird Treaty Act (16 U.S.C. 703 et seq.)

The Migratory Bird Treaty Act (MBTA) prohibits the taking, killing, possession, selling, purchase, barter, offering for sale, transportation and importation of migratory birds, their eggs, parts, and nests.

\section{California Endangered Species Act}

The California Department of Fish and Wildlife (CDFW) administers the California Endangered Species Act (CESA) (California Fish and Game Code Section 2050 et seq.), which serves to conserve threatened or endangered species and their habitats. State laws allow CDFW to review projects for their potential impacts to listed species and their habitats. Compliance with the FESA satisfies the CESA with the CDFW's authorization for incidental take.

\section{California Fish and Game Code}

California Fish and Game Code, Sections 1600 to 1616, regulate development to avoid and mitigate impacts or modification to rivers, streams, or lakes. Modification is defined as diverting or obstructing the natural flow of, or substantially changing or using any material from the bed, channel, or bank of, any river, stream or lake. California Fish and Game Code Section 3503.5 prohibits "take," possession, or destruction of any raptor, its nests or its eggs. 


\section{California Native Plant Protection Act}

The California Native Plant Protection Act of 1977 prohibits the importation, "take", or sale of rare and endangered plants. State-listed plant species are protected under CEQA. California Native Plant Society (CNPS) is a non-governmental conservation organization, which keeps a list of endangered or threatened plant species in California. The list divides the plants into these five categories:

List $1 \mathrm{~A}$ - Considered to be extinct

List 1B - Considered rare, threatened, or endangered in California and elsewhere

List 2 - Considered rare, threatened, or endangered in California, but is more common elsewhere

List 3 - CNPS lacks necessary information to determine if it should be assigned to a list

List 4 - Limited distribution in California

(California Native Plant Society, 2010)

The Porter-Cologne Water Quality Control Act of 1960

The California Water Code Section 13000, charges the State Water Resources Control Board to protect the quality of all state waters. To enforce state regulations, the Regional Water Board issues waste discharge requirement (WDR) permits for wastewater disposal and the construction storm water program. Key locations and local documents

Anderson Marsh State Historical Park

Anderson Marsh State Historical Park is located on the southeast corner of Clearlake. The park provides several habitats, including freshwater marsh, oak woodland, grasslands, and riparian woodland.

\section{Clear Lake Integrated Aquatic Plant Management, 2004}

The Clear Lake Integrated Aquatic Plant Management Plan's objective is to create a healthy aquatic plant community in Clear Lake.

Clear Lake Integrated Watershed Management Plan, 2010

The Clear Lake Integrated Watershed Management Plan identifies opportunities to improve watershed conditions and provides guidance for continuing watershed planning efforts. A few strategies include public education \& outreach, preservation of shoreline habitat and zoning ordinance to protect 
shorelines.

McVicar Wildlife Sanctuary

The McVicar Wildlife Sanctuary is located just west of the Anderson Marsh State Historical Park. The McVicar Wildlife Sanctuary provides habitat to various species of fish and wildlife.

\subsubsection{EXISTING CONDITIONS}

\section{Vegetation, Habitat Types, and Wetlands}

Lacustrine habitats are aquatic environments that contain standing water. Lacustrine habitats support several bird, mammal, reptile, and amphibian species. Clear Lake is considered a lacustrine habitat. An estimated 11 native and 19 introduced fish species are found in Clear Lake, and 3 native species are now presumed extinct (County of Lake Department of Public Works, 2010).

The Environmental Protection Agency (EPA) defines wetlands as areas that are saturated by surface water or groundwater at a frequency and duration sufficient to support a prevalence of vegetation typically adapted for life in such conditions. Wetland plants filter nutrients and sediments (County of Lake Department of Public Works, 2010).

Freshwater Marshes are characterized by periodic to permanent shallow water. Fresh water plants include sedges, rushes, cattails and tules. These plants provide nesting and protection for species like the tricolored and yellow headed blackbirds, the western pond turtle, and Western and Clark's grebes. Largemouth bass, bluegill, black crappie, green sunfish, brown bullhead, white catfish, Sacramento blackfish, tule perch, and prickly sculpin are a few types of fish that can be found in this habitat. Most freshwater marshes in the Clear Lake Watershed are adjacent to Clear Lake (County of Lake Department of Public Works, 2010).

Vernal pools are seasonally flooded depressions found on soils with an impermeable layer such as hardpan, claypan, or volcanic basalt. Freshwater crustaceans, insects, and amphibians are common inhabitants in the vernal pools (CLIWMP, 2010). The CDFW estimates that the Clear Lake Watershed contains 28 vernal pools, which consist of 1,640 acres and are located on mostly private lands (County of 
Lake, Department of Public Works, 2010).

Riparian habitats are strips of land bordering streams, rivers, lakes and other water bodies.

Riparian vegetation is adapted to intermittent flooding and shelters a wide variety of species. Common tree species are willow, ash, alder, and maple. Common shrubs and vines are wild grape, wild rose, blackberry, and poison oak. During spawning time, the Clear Lake hitch, plittail, and Sacramento pike minnow can be found in riparian habitats (County of Lake Department of Public Works, 2010).

Upland Habitat in Clearlake consists of blue oak and interior live oak woodlands and grasslands in low elevation. At middle elevations, chaparral and oak-foothill pine woodlands are the primary plant communities. At higher elevations the plant community consists of mixed conifer, conifer hardwood forests and woodlands. Common annual grasses are wild oats, ripgut brome, red brome, wild barley and foxtail fescue. Common forbs include filarees, turkey mullein, clovers, and popcorn flower (County of Lake, Department of Public Works, 2010).

\section{Natural Areas of Regional Significance}

Wilderness areas in Clearlake are located primarily outside the City boundary to the east. This area consists of hills and wildlife habitat. Also located on the east side of Clearlake is Cache Creek Natural Area, a space with over 70,000 acres of Bureau of Land Management lands and 4,700 acres of State and County lands. Cache Creek flows year-round. Most of the Cache Creek Natural Area is shrubland, and native oaks and grassland are also common habitats as well (County of Lake, Department of Public Works, 2010).

The Clear Lake Watershed Vegetation Map (Map 4.4-1) from the Clearlake 2040 General Plan's Background Report shows the different habitats found in the Clear Lake Watershed. The City is primarily urban, but it is surrounded by hardwood, agriculture and grassland to the North; chaparral to the East; agriculture, hardwood, wetland and grassland to the South; and lacustrine to the West. 


\section{Map 4.4-1 Clear Lake Watershed Vegetation}

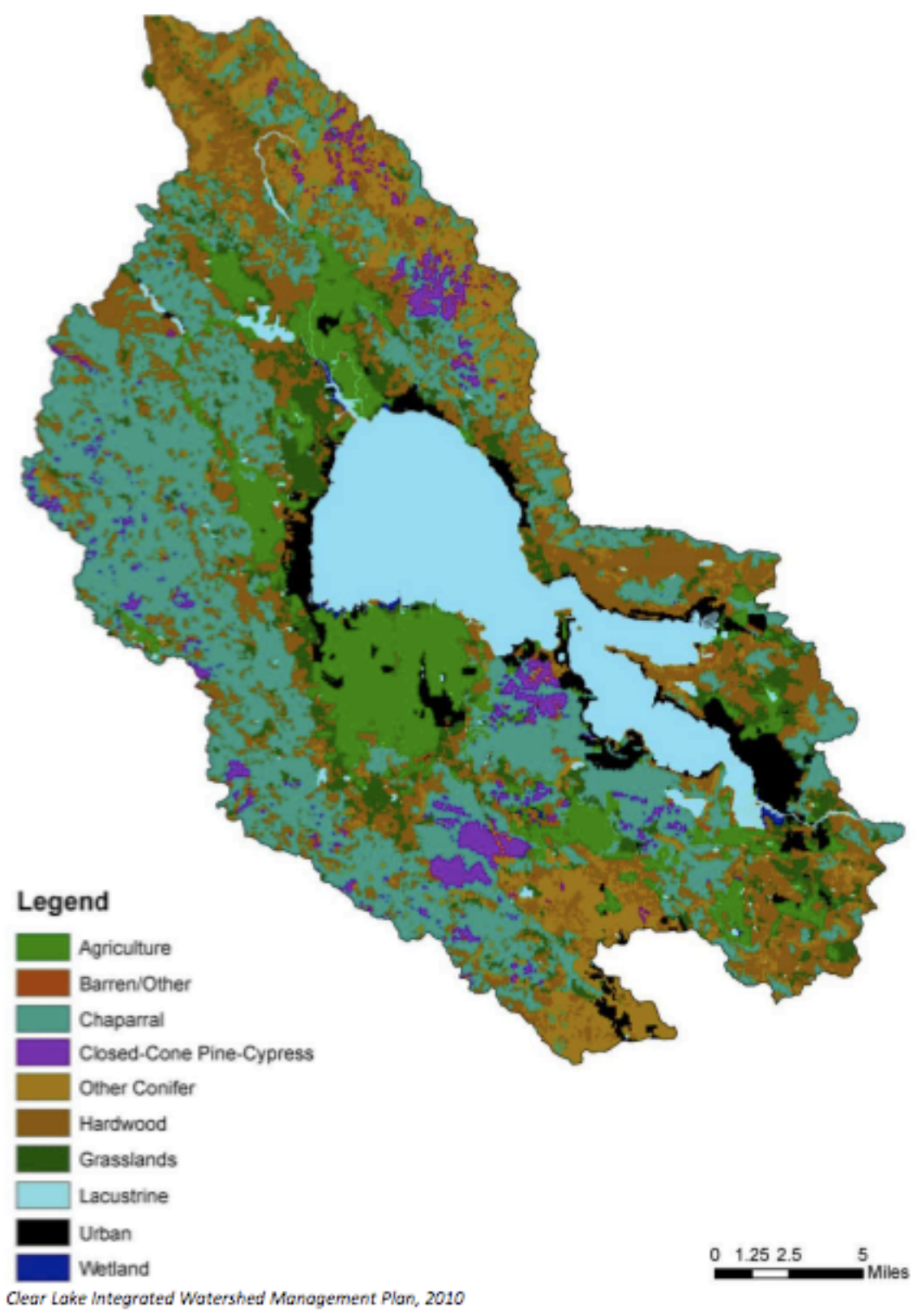

\section{Special-Status Species}

A variety of wildlife and plant communities are present in Clearlake, including sensitive species. Based on the California Natural Diversity Data Base (CNDDB), special-status species from State and/or federal lists may inhabit Clearlake and its vicinity. Appendix A and B respectively lists the special status plant and animal species.

Appendix B lists the animals that are of special-status. Fortunately one of the species, the 
Peregrine Falcon, has been delisted due to recovery. In 2012 the Center for Biological Diversity petitioned for the Clear Lake hitch as an endangered species, and it is currently listed as a candidate for threatened species. This species is only found in Clear Lake and its tributaries. The decline of the Clear Lake hitch's population may indicate the decline of the Lake's well-being, as a result of waterway diversion and pumping, drought, invasive species or pollutants

\subsubsection{STANDARDS OF SIGNIFICANCE}

\subsubsection{CEQA THRESHOLDS}

According to Appendix G of the CEQA Guidelines, the proposed Plan could have a significant effect on the environment with respect to biological resources if it would:

1. Have a substantial adverse effect, either directly or through habitat modifications, on any species identified as a candidate, sensitive or special status species in local or regional plans, policies, or regulations by the California Department of Fish and Game, or U.S. Fish and Wildlife Service;

2. Have a substantial adverse effect on any riparian habitat or other sensitive natural community identified in local or regional plans, policies, regulations, or by the California Department of Fish and Game, or U.S. Fish and Wildlife Service;

3. Have a substantial adverse effect on federally protected wetlands as defined by Section 404 of the Clean Water Act (including, but not limited to, marsh, vernal pool, coastal, etc.) through direct removal, filling, hydrological interruption, or other means;

4. Interfere substantially with the movement of any native resident or migratory fish or wildlife species, or with established native resident or migratory wildlife corridors, or impede the use of native wildlife nursery sites;

5. Conflict with any local policies or ordinances protecting biological resources; or

6. Conflict with the provisions of an adopted Habitat Conservation Plan, Natural Community Conservation Plan, or other approved local, regional, or State habitat conservation plan

\subsubsection{METHODOLOGY}

This review of potential cumulative impacts on biological resources that could result from adoption of the proposed 2040 General Plan was based on review of the proposed General Plan Background Report; the U.S. Department of Fish \& Wildlife's resources; the California Department of Fish \& Wildlife's (CDFW) resources; CDFW's Areas of Conservation Emphasis (ACE-II) Viewer; the California Native Plant Society's resources; and the Center for Biological Diversity resources. The proposed Plan was then compared to the existing conditions to determine the potential impacts on biological resources. Existing state and local regulations and policies related to agricultural resources were also accounted for during the analysis. 


\section{4 .3}

IMPACT DISCUSSION

The following discusses the Plan-specific and cumulative impacts related to biological resources. This discussion is organized by and responds to each of the potential impacts identified in the standards of significance.

BIO-1 Build-out of the proposed Plan would result in potentially significant impacts to specialstatus plant and animal species in the Plan Area.

According to the U.S. Fish and Wildlife database, ACE-II, the City of Clearlake has a mediumhigh level of rare species richness in the urban setting and a low level towards the North and East sides as seen in Map 4.4-2. The Southern end of the City boundary has a high level of rare species richness, which reflects the presence of the Anderson Marsh State Historical Park. The Rare Plant Richness Map 4.4-3 shows that Clearlake has low levels of rare plants within its sphere of influence.

Although the build-out of the proposed plan focuses on building in urbanized spaces and preserving existing open space and agriculture, future development could potentially result in impacts on special-status plant and animal species known or suspected to occur within the City boundaries. Direct impacts on special-status species include the direct loss of individuals or localized populations, the destruction or degradation of essential habitat, or the isolation of subpopulations due to habitat fragmentation. Indirect impacts may include the disruption of reproductive processes, degradation of habitat to an extent that makes it unsuitable for occupation (i.e. invasive species, excessive noise).

The California Natural Diversity Data Base (CNDDB) is an important resource which helped identify the special-status species that may be found in Clearlake's sphere of influence. This data is summarized in Appendix A and B, however, further surveys and assessments are needed at the time of development to confirm the presence or absence of these species on the development sites. The federal, state and local regulations described in Section 4.4.1.1 would protect the special-status species from the potential development proposed in the 2040 General Plan Update. The federal and California Endangered 
Species Acts, Migratory Bird Treaty Act, Fish and Game Code, and California Native Plant Protect Act all inhibit the potential "take" of State, federally, or CNPS (1B) listed plant species.

Stormwater runoff from construction related to this plan may impact aquatic habitats, which special-status fish may inhabit. The State Water Resources Control Board protects the water quality through issuing the General Permit for Discharges of Storm Water Associated with Construction Activity (Construction General permit Order 2009-0009-DWQ). This permit requires the construction site to adequately prevent stormwater runoff through several measures, such as silt fencing. Additionally, the Total Maximum Daily Load Monitoring and Implementation Plan, as mentioned in Chapter 4.9 Hydrology and Water Quality, would provide a secondary level of protection from stormwater runoff.

A potentially significant impact on special-status species is increased wildlife-vehicle collisions on roadways. The population growth in the City and additional visitors to the City under the proposed Plan would increase the number of vehicles on the road. The increased vehicular traffic would increase the likelihood of wildlife-vehicle collisions.

Further, the proposed Plan includes policies and programs that would also protect special-status species from future development. These proposed policies and programs include:

Program CO 1.2.1.1

Implement policies and programs established in the Total Maximum Daily Load Implementation and Monitoring Plan.

Policy CO 1.3.1

Support maintenance of Clear Lake in a pristine condition

Program CO 1.3.1.1

Monitor Occurrence of invasive species.

Program CO 1.3.1.2

Develop an awareness and monitoring program to inform all Clear Lake Users of invasive mussel species.

Policy CO 2.2.1

Promote native landscaping for municipal, residential, and commercial properties.

Program CO 2.2.1.2

Convert to native landscaping for all municipally owned properties.

Program CO 2.2.1.3 
Utilize state assistance for funding and design of native landscapes.

Policy CO 4.1.1

The City will adhere to all federal and state requirements regarding the protection of endangered species.

\section{Map 4.4-2 Clearlake's Statewide Rare Species Richness}

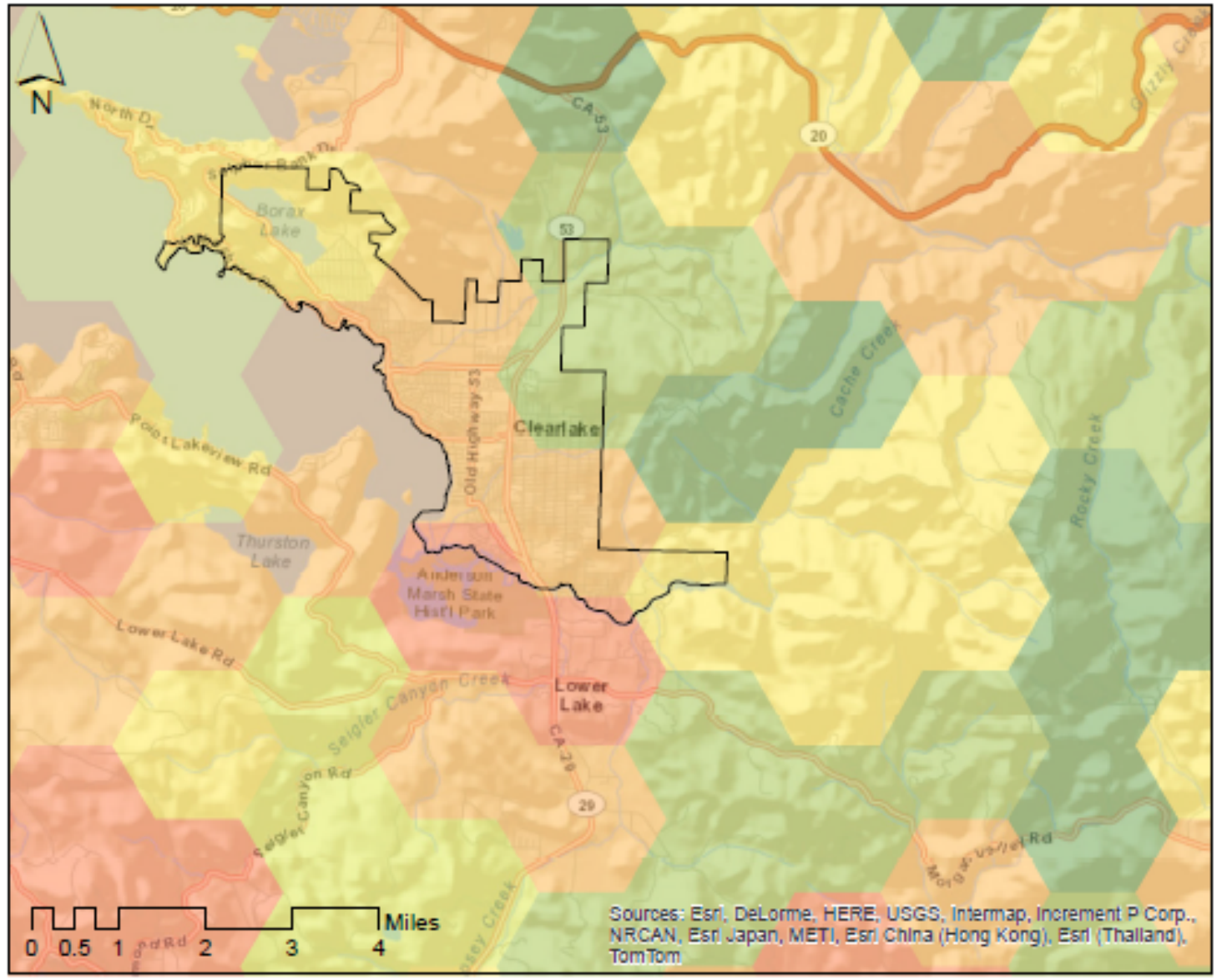

\section{Legend}

city boundary

\section{ACE-II Viewer}

\section{Statewide Rare Species Richness}

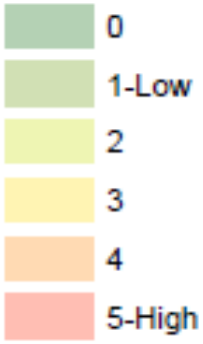

Source: California Department of Fish \& Wildlife ACE-II Viewer, 2014 


\section{Map 4.4-3 Clearlake's Rare Plant Species Richness}

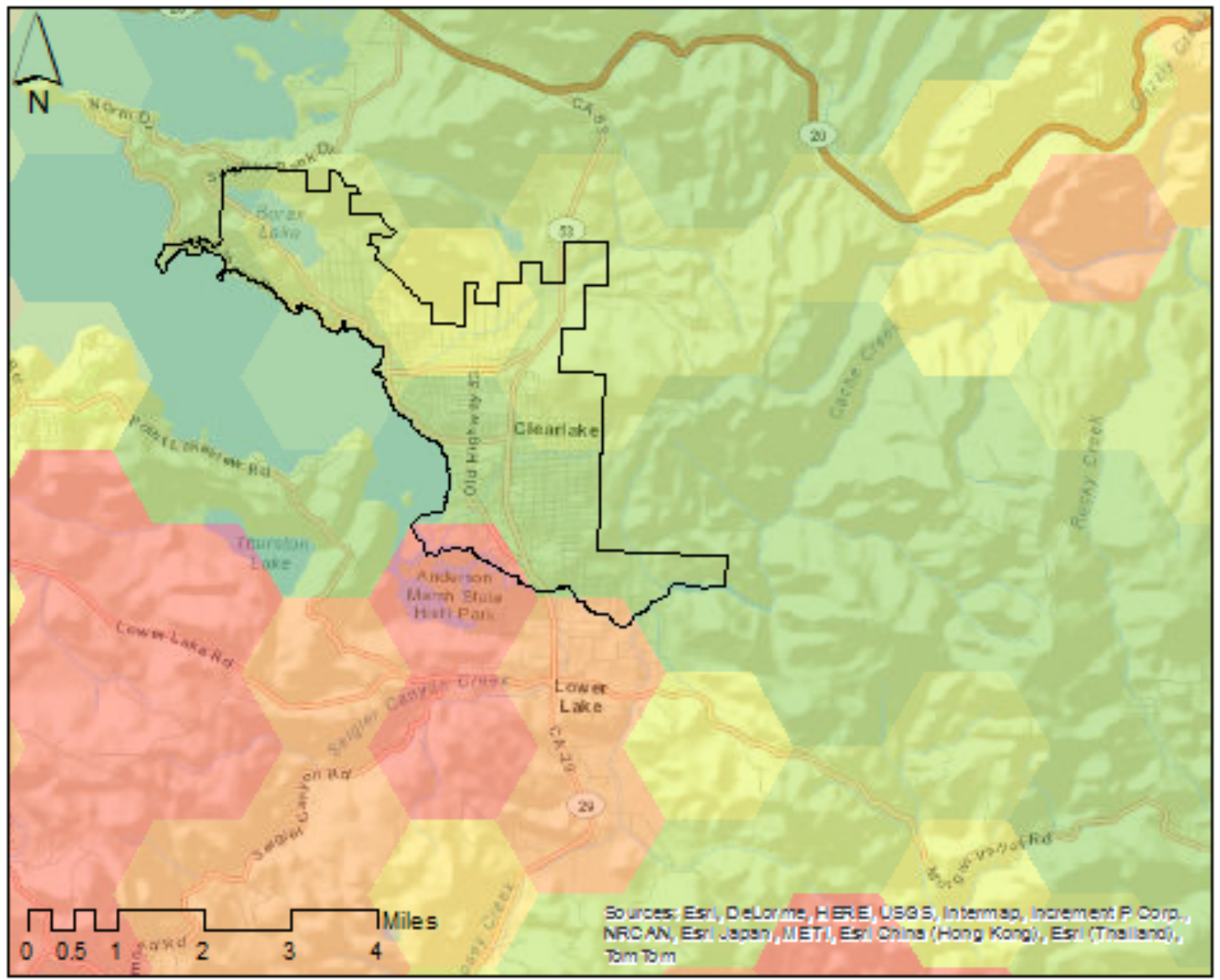

\section{Legend}

$\square$ city boundary

\section{Rare Plant}

\section{Species Richness}

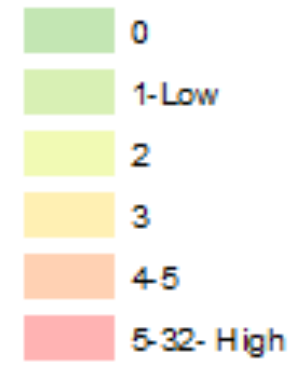

Source: California Department of Fish \& Wildlife ACE-II Viewer, 2014 
Program CO 4.1.1.1

Include in the development review process the potential impact on endangered or threatened plant and animal species.

\section{Policy CO 4.2.1}

The City will conserve existing open space and prevent wildlife habitat loss resulting from new development.

Program CO 4.2.1.1

Establish protected areas to remain as passive open space.

Policy CO 4.3.1

All proposed development will follow CEQA requirements.

Program CO 4.3.1.1

Review and base development approval on environmental impacts.

Policy CO 4.3.2

Subject new proposals for development in protected areas to scrutiny.

Program CO 4.3.2.1

Establish and enforce development standards for areas near or adjacent to protected areas.

Program CO 4.3.3.1

During the development review process, enforce clustered and infill development when building in or near environmentally sensitive areas or habitats.

Policy CO 4.4.1

Require the Lake County list of native vegetation be included among the City's approved list of plants.

Program CO 4.4.1.1

Provide list of approved plants to all residents and developers.

Policy CO 8.1.1

Work with other government land management agencies to preserve and protect biological resources while maintaining the ability to utilize and enjoy the natural resources in the City.

Policy CO 9.1.1

The City will enhance the provision of environmental information and education regarding conservation to residents of all ages.

Program CO 9.2.1.2

Create and maintain a contact list for interested stakeholders who shall be contact in the event of a conservation issue within the City or County.

Policy CO 9.2.2

Incorporate environmental protection and conservation into citywide programs and events.

Program CO 9.2.2.1

Use city events as a means to distribute information on environmental issues within the City and County.

Program CO 9.2.2.2

Create an environmental awareness campaign which highlights current environmental concerns and provides information on low-cost family friendly methods of improving environmental 
quality within the City and County.

Policy OS 4.1.1

Increase protection for environmentally sensitive areas such as wetlands, flood plains, steep slopes, wildlife habitat areas, and unique geological formations.

Program OS 4.1.1.1

Demarcate wildlife habitat areas as protected open spaces.

Program OS 4.1.1.2

Provide educational outreach for the preservation and protection of open space to residents and visitors.

Policy OS 4.2.1

Maximize the amount of protected lake shoreline through purchase, easement, and zoning.

Program OS 4.2.2.1

Support preservation plans for Clear Lake and Anderson Marsh State Historical Park.

Policy OS 6.1.1

The City shall adopt the culture of preservation and protection of native species.

Program OS 6.1.1.1

Partner with land trusts to secure open space lands to assist in protecting native species and managing wildlife habitat.

Policy OS 6.2.1

Integrate open space planning into the City's planning review process.

Program OS 6.2.1.1

Establish and preserve buffers between developed areas and forested areas, fields, stream corridors, wetlands, and other open spaces.

Program OS 6.2.1.2

Use conservation design, unit clustering and infill, and non-traditional housing development pattern in order to prevent new housing from encroaching on preserved and open space areas, including forested land, fields, habitat corridors, and wetlands.

Applicable Federal, State and local regulations, together with the proposed Plan's policies and programs would reduce potential impact to the special-status species and their habitats. However, potentially significant impacts from increased wildlife-car collisions would likely occur.

\section{Applicable Regulations:}

Federal Endangered Species Act

Migratory Bird Treaty Act

California Endangered Species Act

California Fish and Game Code

California Native Plant Protection Act 
The Porter-Cologne Water Quality Control Act of 1960

Significance Before Mitigation: Potentially significant.

BIO-2 Build-out of the proposed Plan would result in less than significant impacts to wetlands, riparian habitat and sensitive natural communities in the Plan Area.

According to the U.S. Fish and Wildlife database, ACE-II, the City has no riparian habitat within the City limits, but is surrounded by some to its North, South and East boundaries. Map 4.4-4 shows these locations. Map 4.4-5 shows that Clearlake has wetland habitat on its Western side, which borders the freshwater lake. Despite the presence of wetland habitat, Clearlake has low levels of sensitive habitats as seen in Map 4.4-6, because the indicated wetland habitats are already urbanized.

Although the build-out of the proposed plan focuses on building in urbanized spaces and preserving existing open space and agriculture, future development could potentially impacts riparian, wetland and sensitive habitats. Direct impacts on these sensitive habitats may include habitat loss, degradation of habitat, alteration of hydrologic systems, such as increased impervious surfaces, and any physical alteration of the listed habitats. Indirect impacts include any physical change in the environment, which is not immediately related to the proposed Plan, but may cause an adverse effect.

The federal, State and local regulations described in Section 4.4.1.1 would mitigate impact on the riparian, wetland and sensitive habitats from the potential development proposed in the 2040 General Plan Update. The Federal Clean Water Act and Porter-Cologne Water Quality Control Act regulate the water quality entering the U.S. and State water bodies, respectively. These water quality regulations assist in protecting sensitive habitats from pollution, but also from the alteration of waterways (through dredging, infill, or other method). 


\section{Map 4.4-4 Clearlake's Riparian Habitats}

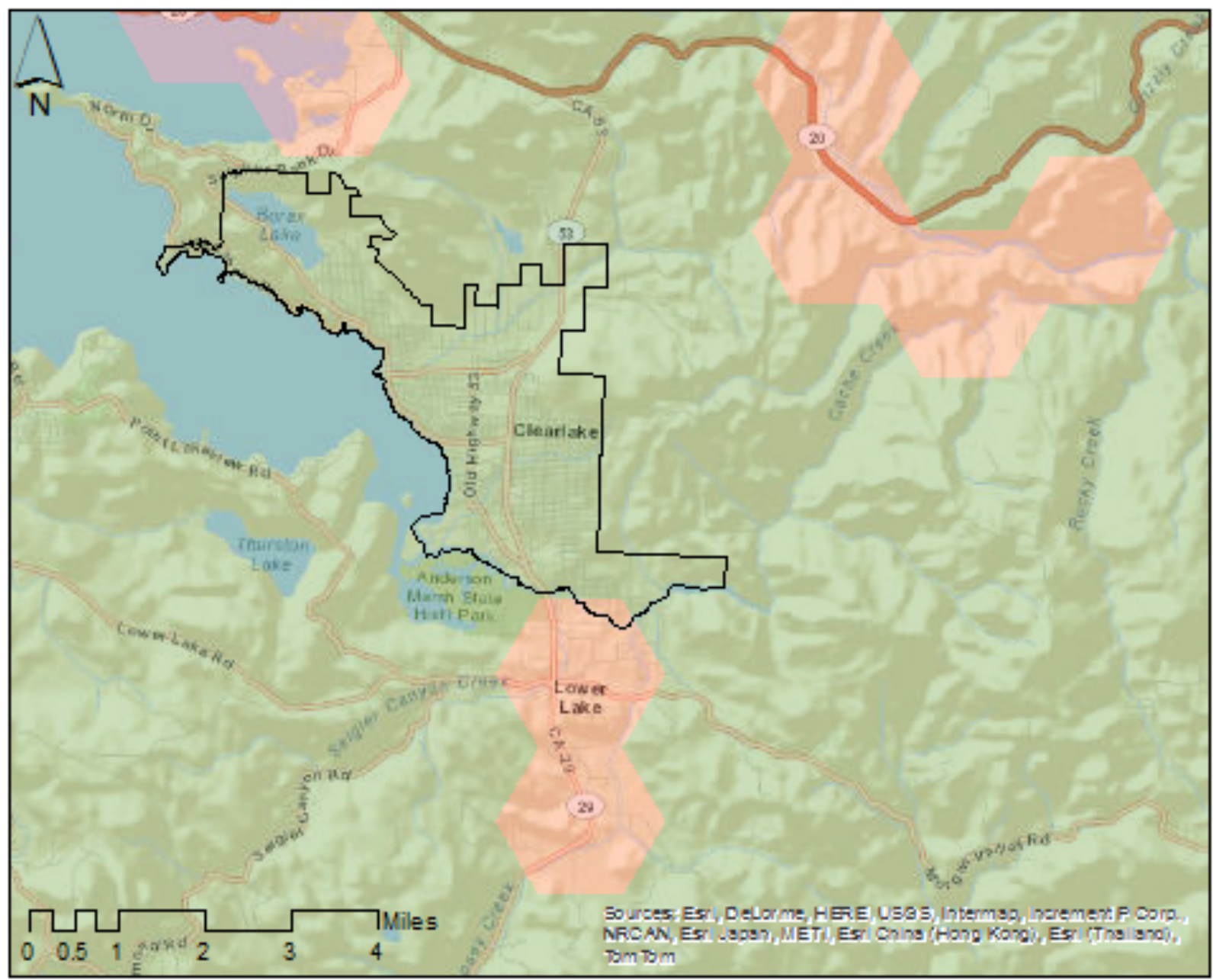

\section{Legend}

$\square$ city boundary

\section{Sensitive Riparian}

\section{Habitats}

$$
\begin{aligned}
& \text { Absent } \\
& \text { Present }
\end{aligned}
$$

Source: California Department of Fish \& Wildlife ACE-II Viewer, 2014 


\title{
Map 4.4-5 Clearlake's Wetland Habitats
}

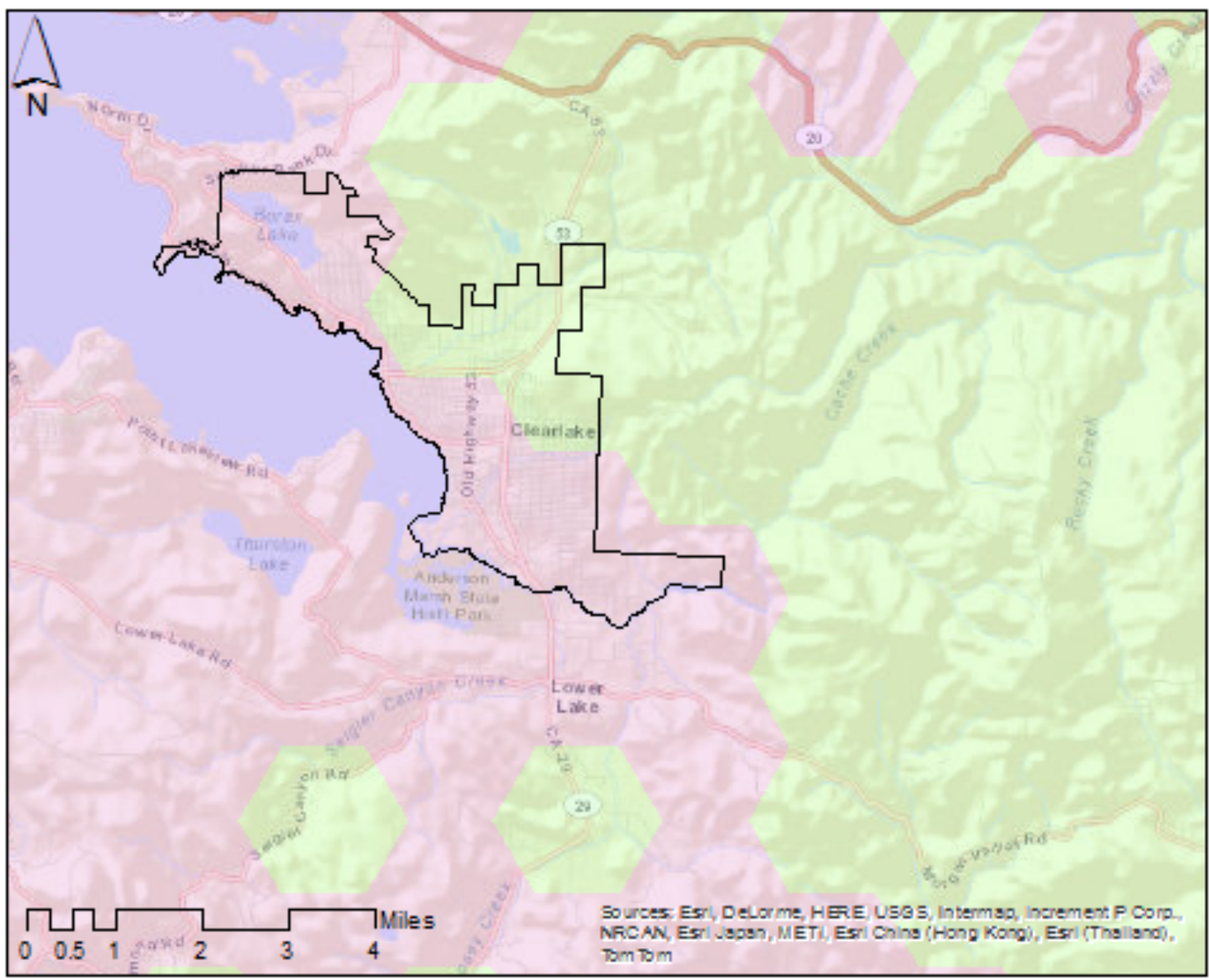

\section{Legend}

city boundary

Sensitive Wetland

\section{Wetland}

\author{
Absent \\ Present
}

Source: California Department of Fish \& Wildlife ACE-II Viewer, 2014 


\section{Map 4.4-6 Clearlake's Statewide Sensitive Habitats}

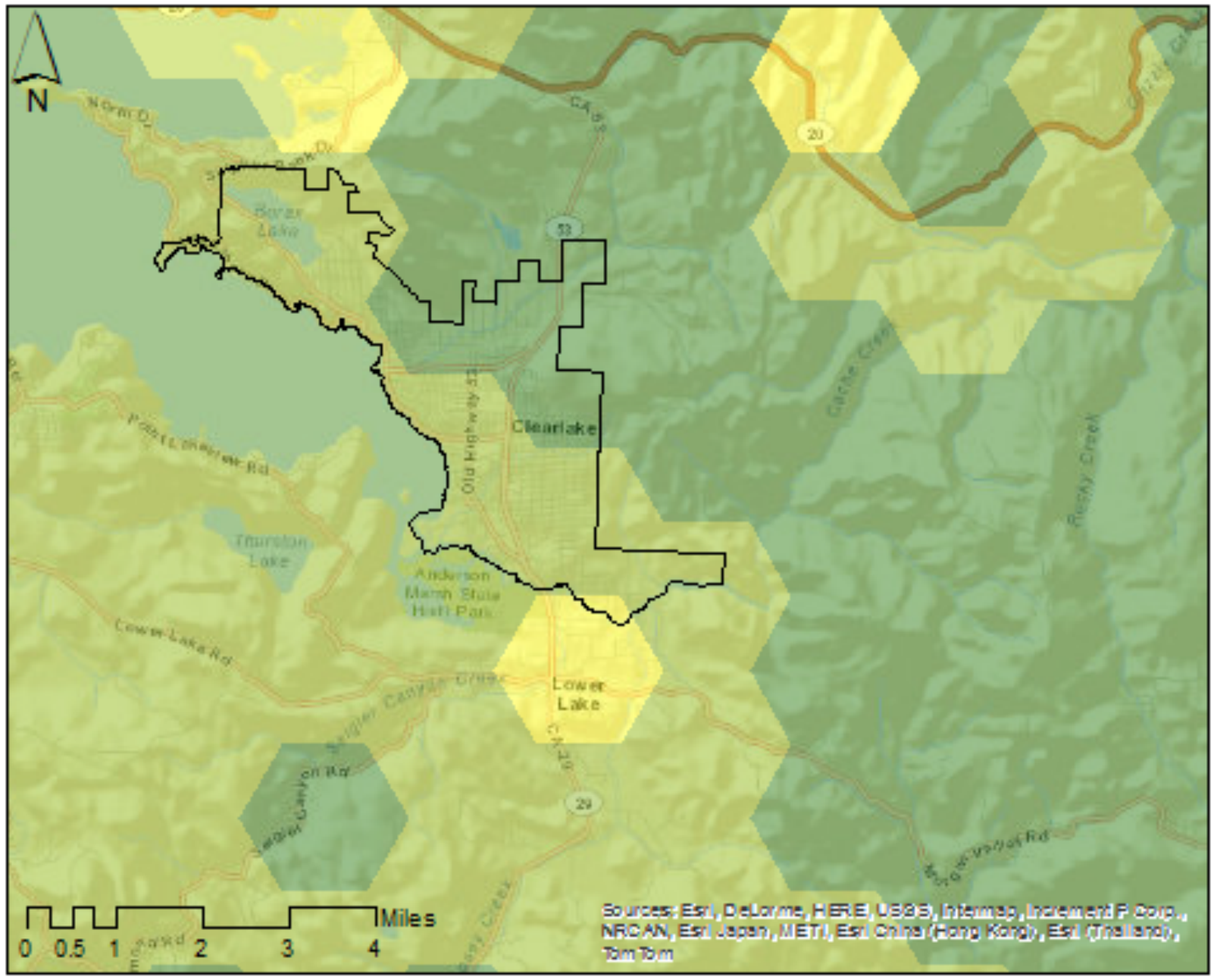

\section{Legend}

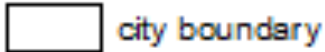

\section{Statewide}

\section{Sen sitive Habitats}

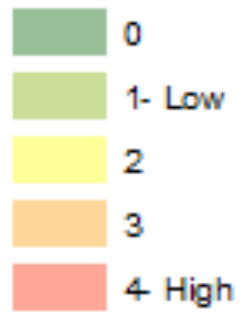

Source: California Department of Fish \& Wildlife ACE-II Viewer, 2014 
New development and redevelopment according to the proposed Plan would need to follow federal and State regulations that help protect these sensitive habitats. During the construction process additional requirements to protect the environment are included to mitigate potential impact on these natural resources. Further, the proposed Plan includes the following policies and programs that would also protect special-status species from future development. These proposed policies and programs include:

Policy CO 1.1.1

Meet local, state, and federal standards for water quality.

Program CO 1.1.1.1

Continue to participate in the Clear Lake Integrated Watershed Management Plan.

Policy CO 1.2.1

Conform to the requirements for allowable levels of loading.

Program CO 1.2.1.1

Implement policies and programs established in the Total Maximum Daily Load Implementation and Monitoring Plan.

Policy CO 1.3.1

Support maintenance of Clear Lake in a pristine condition

Program CO 1.3.1.1

Monitor Occurrence of invasive species.

Program CO 1.3.1.2

Develop an awareness and monitoring program to inform all Clear Lake Users of invasive mussel species.

Policy CO 2.2.1

Promote native landscaping for municipal, residential, and commercial properties.

Program CO 2.2.1.1

Develop a set of approved water conservation techniques and best management practices to guide streamlined approval of development projects.

Program CO 2.2.1.2

Convert to native landscaping for all municipally owned properties.

Program CO 2.2.1.3

Utilize state assistance for funding and design of native landscapes.

Policy CO 2.3.1

The City will maintain compliance with National Pollution Discharge Elimination System permits and Waste Discharge Requirements for sewage treatment, collection, and disposal.

Program CO 2.3.1.1

Conduct periodic checks of wastewater treatment facilities and pollutant levels of effluent.

Program CO 2.3.1.2

Establish City protocol for monitoring and enforcing compliance with water treatment procedures. 
Policy CO 2.3.2

Promote use of low impact development (LID) practices.

Program CO 2.3.2.1

Develop a comprehensive database of affordable LID standards for new development projects.

Program CO 2.3.2.2

Provide incentives for developers to utilize City approved LID methods for new development projects.

\section{Policy CO 2.3.3}

The City will give priority to approving new development that can connect to existing central sewer system.

Program CO 2.3.3.1

Establish requirements under the development review process for new development and connection to an existing central sewer system.

Policy CO 2.3.4

Promote proper maintenance of septic tanks.

Program CO 2.3.4.1

Develop residential awareness campaign to inform residents of proper septic tank maintenance procedures and resources.

Program CO 2.3.4.2

Establish a Citywide inspection system to monitor resident compliance with minimum septic tank standards.

Policy CO 4.2.1

The City will conserve existing open space and prevent wildlife habitat loss resulting from new development.

Program CO 4.2.1.1

Establish protected areas to remain as passive open space.

Policy CO 4.3.1

All proposed development will follow CEQA requirements.

Program CO 4.3.1.1

Review and base development approval on environmental impacts.

Policy CO 4.3.2

Subject new proposals for development in protected areas to scrutiny.

Program CO 4.3.2.1

Establish and enforce development standards for areas near or adjacent to protected areas.

Program CO 4.3.3.1

During the development review process, enforce clustered and infill development when building in or near environmentally sensitive areas or habitats.

Policy CO 4.4.1

Require the Lake County list of native vegetation be included among the City's approved list of plants. 
Program CO 4.4.1.1

Provide list of approved plants to all residents and developers.

\section{Policy CO 8.1.1}

Work with other government land management agencies to preserve and protect biological resources while maintaining the ability to utilize and enjoy the natural resources in the City.

Policy CO 9.1.1

The City will enhance the provision of environmental information and education regarding conservation to residents of all ages.

Program CO 9.2.1.1

Establish City protocol on advertising and alerting residents and stakeholders of public comment periods for new development proposals or other environmental issues.

Policy CO 9.2.2

Incorporate environmental protection and conservation into citywide programs and events.

Program CO 9.2.2.1

Use city events as a means to distribute information on environmental issues within the City and County.

Program CO 9.2.2.2

Create an environmental awareness campaign which highlights current environmental concerns and provides information on low-cost family friendly methods of improving environmental quality within the City and County.

Policy OS 4.1.1

Increase protection for environmentally sensitive areas such as wetlands, flood plains, steep slopes, wildlife habitat areas, and unique geological formations.

Program OS 4.1.1.1

Demarcate wildlife habitat areas as protected open spaces.

Program OS 4.1.1.2

Provide educational outreach for the preservation and protection of open space to residents and visitors.

Policy OS 4.2.1

Maximize the amount of protected lake shoreline through purchase, easement, and zoning.

Program OS 4.2.2.1

Support preservation plans for Clear Lake and Anderson Marsh State Historical Park.

Policy OS 6.2.1

Integrate open space planning into the City's planning review process.

Program OS 6.2.1.1

Establish and preserve buffers between developed areas and forested areas, fields, stream corridors, wetlands, and other open spaces.

Program OS 6.2.1.2

Use conservation design, unit clustering and infill, and non-traditional housing development pattern in order to prevent new housing from encroaching on preserved and open space areas, 
including forested land, fields, habitat corridors, and wetlands.

Applicable Federal, State and local regulations, together with the proposed Plan's policies and

programs would reduce potential impact to the riparian, wetland, and sensitive natural communities to less than significant levels. Therefore, impacts from the proposed Plan would be less-than-significant.

\section{Applicable Regulations:}

California Department of Fish and Game Code

Federal Clean Water Act- Section 404

The Porter-Cologne Water Quality Control Act of 1960

Significance Before Mitigation: Less than significant.

BIO-3 Build-out of the proposed Plan would result in less than significant impacts to state or federally protected wetlands and/or waters of the United States.

Federally protected wetlands are those that have been delineated as jurisdictional waters of the United States by the U.S. Army Corps of Engineers (USACE). Section 404 of the Clean Water Act states the policy of "no net loss" of wetlands and also regulates the discharge into waters of the U.S. If a project adversely affects waters of the U.S. the USACE usually requires an in-kind mitigation at a ratio of at least 1:1 to issue a permit authorizing the development. Map 4.4-7 shows that Clearlake has federally protected wetlands located within the City's boundaries, just south of Borax Lake. South of the City's boundaries is another federally protected wetland in the Anderson Marsh State Historical Park.

Implementation of the proposed General Plan could allow new and infill development which could impact state or federally protected wetlands and/or waters of the United States. However, the build-out of the proposed plan focuses on building in urbanized spaces and preserving existing natural resources, including wetlands. Direct impacts on these sensitive habitats may include habitat loss, degradation of habitat, alteration of hydrologic systems, such as increased impervious surfaces, and any physical alteration of the listed habitats. Indirect impacts include any physical change in the environment, which is not immediately related to the proposed Plan, but may cause an adverse effect. 
The federal, State and local regulations described in Section 4.4.1.1 would mitigate impact on the federally protected wetlands from the potential development proposed in the proposed Plan. The Federal Clean Water Act and Porter-Cologne Water Quality Control Act regulate the water quality entering the U.S. and State water bodies, respectively. These water quality regulations assist in protecting sensitive habitats from pollution, but also from the alteration of waterways (through dredging, infill, or other method).

\section{Map 4.4-7 Clearlake's Federally Protected Wetlands}

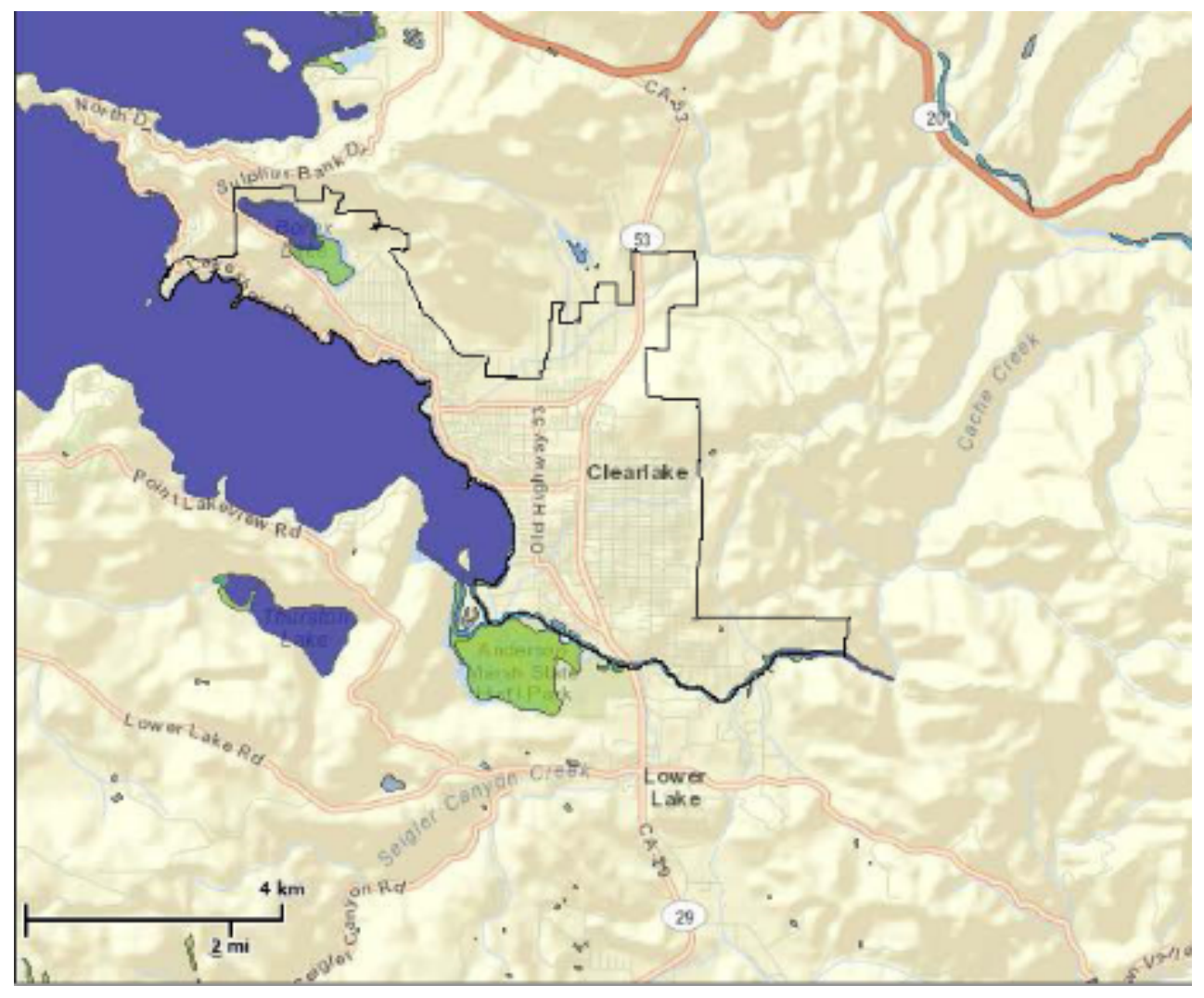

\section{Wetlands}

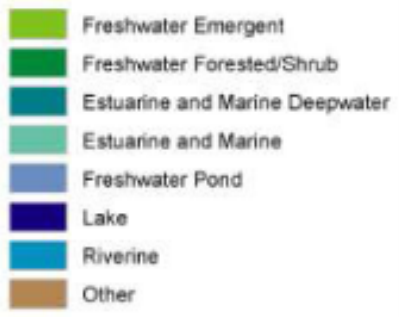

Source: United States Fish and Wildlife Service Wetlands Mapper, 2014 
Further, the proposed Plan includes policies and programs that would protect special-status species from future development. These proposed policies and programs include:

Policy CO 1.1.1

Meet local, state, and federal standards for water quality.

Program CO 1.1.1.1

Continue to participate in the Clear Lake Integrated Watershed Management Plan.

Policy CO 1.2.1

Conform to the requirements for allowable levels of loading.

Program CO 1.2.1.1

Implement policies and programs established in the Total Maximum Daily Load Implementation and Monitoring Plan.

Policy CO 1.3.1

Support maintenance of Clear Lake in a pristine condition

Program CO 1.3.1.1

Monitor Occurrence of invasive species.

Program CO 1.3.1.2

Develop an awareness and monitoring program to inform all Clear Lake Users of invasive mussel species.

Policy CO 2.2.1

Promote native landscaping for municipal, residential, and commercial properties.

Program CO 2.2.1.1

Develop a set of approved water conservation techniques and best management practices to guide streamlined approval of development projects.

Program CO 2.2.1.2

Convert to native landscaping for all municipally owned properties.

Program CO 2.2.1.3

Utilize state assistance for funding and design of native landscapes.

Policy CO 2.3.1

The City will maintain compliance with National Pollution Discharge Elimination System permits and Waste Discharge Requirements for sewage treatment, collection, and disposal.

Program CO 2.3.1.1

Conduct periodic checks of wastewater treatment facilities and pollutant levels of effluent.

Program CO 2.3.1.2

Establish City protocol for monitoring and enforcing compliance with water treatment procedures.

Policy CO 2.3.2

Promote use of low impact development (LID) practices.

Program CO 2.3.2.1

Develop a comprehensive database of affordable LID standards for new development projects. 
Program CO 2.3.2.2

Provide incentives for developers to utilize City approved LID methods for new development projects.

\section{Policy CO 2.3.3}

The City will give priority to approving new development that can connect to the existing central sewer system.

Program CO 2.3.3.1

Establish requirements under the development review process for new development and connection to an existing central sewer system.

Policy CO 2.3.4

Promote proper maintenance of septic tanks.

Program CO 2.3.4.1

Develop residential awareness campaign to inform residents of proper septic tank maintenance procedures and resources.

Program CO 2.3.4.2

Establish a Citywide inspection system to monitor resident compliance with minimum septic tank standards.

Policy CO 4.2.1

The City will conserve existing open space and prevent wildlife habitat loss resulting from new development.

Program CO 4.2.1.1

Establish protected areas to remain as passive open space.

Policy CO 4.3.1

All proposed development will follow CEQA requirements.

Program CO 4.3.1.1

Review and base development approval on environmental impacts.

Policy CO 4.3.2

Subject new proposals for development in protected areas to scrutiny.

Program CO 4.3.2.1

Establish and enforce development standards for areas near or adjacent to protected areas.

Program CO 4.3.3.1

During the development review process, enforce clustered and infill development when building in or near environmentally sensitive areas or habitats.

Policy CO 4.4.1

Require the Lake County list of native vegetation be included among the City's approved list of plants.

Program CO 4.4.1.1

Provide list of approved plants to all residents and developers.

Policy CO 8.1.1

Work with other government land management agencies to preserve and protect biological resources while maintaining the ability to utilize and enjoy the natural resources in the City. 
Policy CO 9.1.1

The City will enhance the provision of environmental information and education regarding conservation to residents of all ages.

Program CO 9.2.1.1

Establish City protocol on advertising and alerting residents and stakeholders of public comment periods for new development proposals or other environmental issues.

Policy CO 9.2.2

Incorporate environmental protection and conservation into citywide programs and events.

Program CO 9.2.2.1

Use city events as a means to distribute information on environmental issues within the City and County.

Program CO 9.2.2.2

Create an environmental awareness campaign which highlights current environmental concerns and provides information on low-cost family friendly methods of improving environmental quality within the City and County.

Policy OS 4.1.1

Increase protection for environmentally sensitive areas such as wetlands, flood plains, steep slopes, wildlife habitat areas, and unique geological formations.

Program OS 4.1.1.1

Demarcate wildlife habitat areas as protected open spaces.

Program OS 4.1.1.2

Provide educational outreach for the preservation and protection of open space to residents and visitors.

\section{Policy OS 4.2.1}

Maximize the amount of protected lake shoreline through purchase, easement, and zoning.

Program OS 4.2.2.1

Support preservation plans for Clear Lake and Anderson Marsh State Historical Park.

Policy OS 6.2.1

Integrate open space planning into the City's planning review process.

Program OS 6.2.1.1

Establish and preserve buffers between developed areas and forested areas, fields, stream corridors, wetlands, and other open spaces.

Program OS 6.2.1.2

Use conservation design, unit clustering and infill, and non-traditional housing development pattern in order to prevent new housing from encroaching on preserved and open space areas, including forested land, fields, habitat corridors, and wetlands.

\section{Applicable Regulations:}

\section{California Fish and Game Code}

Federal Clean Water Act- Section 404 
Porter-Cologne Water Quality Control Act

Significance Before Mitigation: Less than significant.

BIO-4 Build-out of the proposed Plan would result in less-than-significant impacts to the movement of native resident or migratory fish or wildlife species, or with established native resident or migratory wildlife corridors, or impede the use of native wildlife nursery sites.

The proposed General Plan would result in a significant impact if new development would interfere with species movement or involve barriers or threats within wildlife corridors. Movement of wildlife can fall into three categories: movement along corridors, dispersal movements (juveniles colonizing new areas), and temporal migration movements (seasonal movements).

Given the urbanized environment of the City, its vehicular infrastructure, and human and pet presence, opportunities for wildlife movement in the urbanized portion of the city are already minimal. The U.S. Fish and Wildlife Map 4.4-8 shows that Clearlake has zero habitat that is essential to connectivity for statewide wildlife migration. Wildlife corridors of local importance may include areas along Clear Lake and its tributaries. The local Fish and Wildlife Department identified the wildlife corridor connecting Clear Lake to Borax Lake as one of local importance. This wildlife corridor is left undeveloped and protected in the proposed plan. 


\section{Map 4.4-8 Statewide Essential Connectivity Areas}

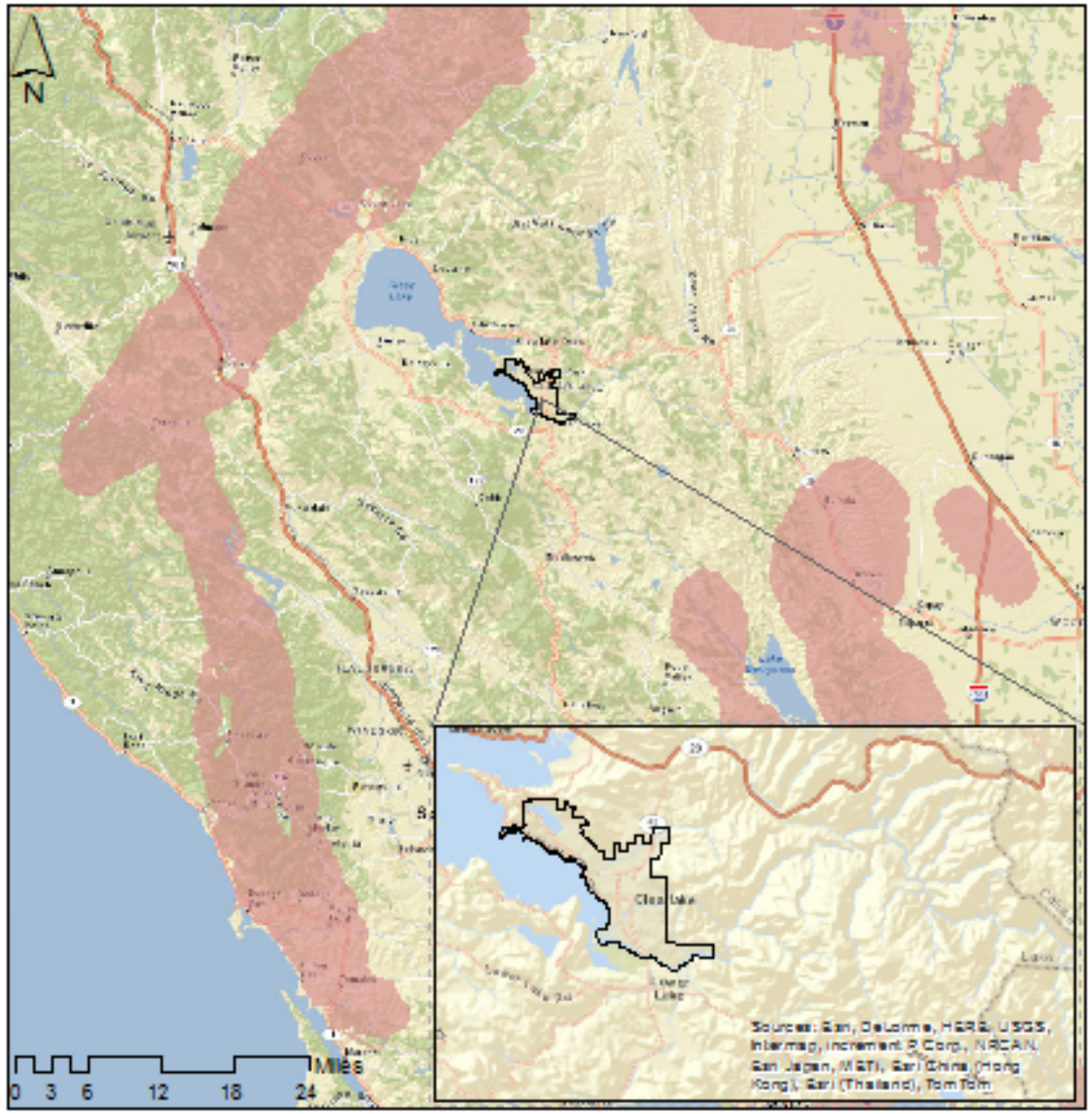

\section{Legend}

$\square$ aty boundary

Essental ConnectivityAreas

Source: California Department of Fish \& Wildlife ACE-II Viewer, 2014

The build-out of the proposed plan focuses on building in urbanized spaces and preserving existing open space and agriculture. Therefore, the proposed Plan would not interfere substantially with the movement of any native resident or migratory fish or wildlife species, or with established native resident or 
migratory wildlife corridors, or impede the use of native wildlife nursery sites.

Further, the proposed Plan includes policies and programs that would also protect the movement of native species, and mitigate the potential impact to a less than significant level. These proposed policies and programs include:

Policy CO 1.3.1

Support maintenance of Clear Lake in a pristine condition

Policy CO 4.1.1

The City will adhere to all federal and state requirements regarding the protection of endangered species.

Program CO 4.1.1.1

Include in the development review process the potential impact on endangered or threatened plant and animal species.

\section{Policy CO 4.2.1}

The City will conserve existing open space and prevent wildlife habitat loss resulting from new development.

Program CO 4.2.1.1

Establish protected areas to remain as passive open space.

Policy CO 4.3.1

All proposed development will follow CEQA requirements.

Program CO 4.3.1.1

Review and base development approval on environmental impacts.

Policy CO 4.3.2

Subject new proposals for development in protected areas to scrutiny.

Program CO 4.3.2.1

Establish and enforce development standards for areas near or adjacent to protected areas.

Program CO 4.3.3.1

During the development review process, enforce clustered and infill development when building in or near environmentally sensitive areas or habitats.

Policy CO 8.1.1

Work with other government land management agencies to preserve and protect biological resources while maintaining the ability to utilize and enjoy the natural resources in the City.

Policy CO 9.1.1

The City will enhance the provision of environmental information and education regarding conservation to residents of all ages.

Program CO 9.2.1.2

Create and maintain a contact list for interested stakeholders who shall be contact in the event of a conservation issue within the City or County. 
Policy CO 9.2.2

Incorporate environmental protection and conservation into citywide programs and events.

Program CO 9.2.2.1

Use city events as a means to distribute information on environmental issues within the City and County.

Program CO 9.2.2.2

Create an environmental awareness campaign which highlights current environmental concerns and provides information on low-cost family friendly methods of improving environmental quality within the City and County.

Policy OS 4.1.1

Increase protection for environmentally sensitive areas such as wetlands, flood plains, steep slopes, wildlife habitat areas, and unique geological formations.

Program OS 4.1.1.1

Demarcate wildlife habitat areas as protected open spaces.

Policy OS 4.2.1

Maximize the amount of protected lake shoreline through purchase, easement, and zoning.

Program OS 4.2.2.1

Support preservation plans for Clear Lake and Anderson Marsh State Historical Park.

Policy OS 6.1.1

The City shall adopt the culture of preservation and protection of native species.

Program OS 6.1.1.1

Partner with land trusts to secure open space lands to assist in protecting native species and managing wildlife habitat.

Policy OS 6.2.1

Integrate open space planning into the City's planning review process.

Program OS 6.2.1.1

Establish and preserve buffers between developed areas and forested areas, fields, stream corridors, wetlands, and other open spaces.

Program OS 6.2.1.2

Use conservation design, unit clustering and infill, and non-traditional housing development pattern in order to prevent new housing from encroaching on preserved and open space areas, including forested land, fields, habitat corridors, and wetlands.

Applicable Federal, State and local regulations, together with the proposed Plan's policies and programs would reduce potential impact to the movement of wildlife. Therefore, impacts from the proposed Plan would be less-than-significant.

\section{Applicable Regulations:}

Federal Endangered Species Act

Migratory Bird Treaty Act 
California Endangered Species Act

California Fish and Game Code

Significance Before Mitigation: Less than significant.

BIO-5 The proposed Plan would result in less-than-significant impacts, with regards to conflicts with local policies or ordinances protecting biological resources.

The proposed Plan would not conflict with any local policies or ordinances protecting biological resources, since there are no existing local policies or ordinances governing biological resources apart from state and federal mandates. The proposed Plan includes policies and programs that would support existing local policies and ordinances, and reduce to potential impacts to less than significant levels. These proposed policies and programs include:

Program CO 1.1.1.1

Continue to participate in the Clear Lake Integrated Watershed Management Plan.

Policy CO 4.1.1

The City will adhere to all federal and state requirements regarding the protection of endangered species.

Policy CO 4.3.1

All proposed development will follow CEQA requirements.

Policy CO 8.1.1

Work with other government land management agencies to preserve and protect biological resources while maintaining the ability to utilize and enjoy the natural resources in the City.

Program CO 9.2.1.2

Create and maintain a contact list for interested stakeholders who shall be contact in the event of a conservation issue within the City or County.

Program OS 4.2.2.1

Support preservation plans for Clear Lake and Anderson Marsh State Historical Park.

Policy OS 6.2.1

Integrate open space planning into the City's planning review process.

The proposed Plan's policies and programs are cohesive with existing local policies and ordinances. Therefore, impacts from the proposed Plan would be less-than-significant.

Applicable Regulations: N/A

Significance Before Mitigation: Less-than-significant. 
BIO-6 The proposed Plan would result in less-than-significant impacts related to conflicts with the provision of an adopted Habitat Conservation Plan.

The City of Clearlake does not have legal Habitat Conservation Plans (HCPs) as defined in the federal Endangered Species Act Section 10(a)(2)(A); however, this section considers potential impacts related to conflicts with the Clear Lake Integrated Watershed Management Plan and the Clear Lake Integrated Aquatic Plant Management Plan.

The Clear Lake Integrated Watershed Management Plan identifies opportunities to improve watershed conditions and provides guidance for continuing watershed planning efforts. A few strategies discussed include: public education \& outreach, preservation of shoreline habitat and zoning ordinance (Waterway Combining District, Shoreline ordinance) to protect shorelines.

The Clear Lake Integrated Aquatic Plant Management Plan is a more specific strategic plan to create a healthy aquatic ecosystem in Clear Lake. Neither of these documents would conflict with the City of Clearlake's 2040 General Plan Update's policies and programs. These proposed policies and programs include:

Program CO 1.1.1.1

Continue to participate in the Clear Lake Integrated Watershed Management Plan.

Policy CO 4.1.1

The City will adhere to all federal and state requirements regarding the protection of endangered species.

Policy CO 8.1.1

Work with other government land management agencies to preserve and protect biological resources while maintaining the ability to utilize and enjoy the natural resources in the City.

Program CO 9.2.1.2

Create and maintain a contact list for interested stakeholders who shall be contact in the event of a conservation issue within the City or County.

Program OS 4.2.2.1

Support preservation plans for Clear Lake and Anderson Marsh State Historical Park.

The proposed Plan's policies and programs are cohesive with existing local plans related to habitat

conservation. Therefore, impacts from the proposed Plan would be less-than-significant.

Applicable Regulations: N/A 
Significance Before Mitigation: Less-than-significant.

BIO-7

The proposed Plan would result in less than significant cumulative impacts related to biological resources.

This section analyzes potential impacts to biological resources that could result from a combination of the proposed Plan and other past, present, and reasonably foreseeable development. Although the plan proposes development in already built space, the construction process may impact biological resources through noise, dust, or other disturbances. Cumulatively, the plan has the potential of causing significant impact on biological resources, because of the City's close proximity to key natural resources, such as Clear Lake and the Anderson Marsh State Historical Park.

Build-out of the proposed Plan would not include any additional development in open space or agricultural areas. Policies and programs included in the proposed Plan promote context-sensitive development and minimize impacts on natural resources. Additionally, future development under the proposed Plan would be subject to separate project-level environmental review to identify and mitigate specific impacts to biological resources. Therefore, with observance of applicable federal, State, and local regulations and implementation of mitigation measures, the proposed Plan would result in less-thansignificant cumulative impacts on biological resources.

Significance Before Mitigation: Less than significant. 


\subsubsection{SUMMARY OF SIGNIFICANT IMPACTS AND MITIGATION}

\section{MEASURES}

BIO-1 Build-out of the proposed Plan would result in potentially significant impacts to specialstatus plant and animal species in the Plan Area.

\section{Mitigation Measure BIO-1:}

A potential impact on special-status species is increased wildlife-vehicle collisions on roadways, due to increased traffic under the proposed Plan. In order to mitigate this impact to less than significant levels, the city shall implement best practices for reducing wildlife-vehicle collisions. This could include the implementation of one or more of the following actions:

1. Change driver behavior (roadway wildlife warning signs, decrease speed limits, traffic calming strategies)

2. Increase visibility (animal detection systems, roadway lighting, wider road striping, reflective collars for animals)

3. Influence animal behavior (olfactory repellents, hazing, minimize nutritional value of vegetation near roads, increase median width)

4. Physically separate wildlife from roadway (wildlife fencing, wildlife under/overpasses)

Significance After Mitigation: Less-than-significant. 


\section{Biological Resources Bibliography}

California Department of Fish and Wildlife. (2014). Areas of Conservation Emphasis (ACE-II) viewer. Retrieved from http://imaps.dfg.ca.gov/maps/ace/

California Department of Fish and Wildlife. (2010). Fish and Game Code in the California Public Resources Code. Retrieved from http://www .leginfo.ca.gov/cgibin/calawquery?codesection=fgc \&codebody $=\&$ hits=20

California Department of Fish and Wildlife. (2013). California endangered species act. Retrieved from http://www.dfg.ca.gov/habcon/cesa/

California Department of Fish and Game. (2010). CNNDB quick viewer. Retrieved from http://imaps.dfg.ca.gov/viewers/cnddb_quickviewer/app.asp

California Department of Parks and Recreation. (2012). Anderson Marsh State Historic Park. http://www.parks.ca.gov/?page_id=483

California Department of Water Resources. (2009). California Water Plan Update 2009. Retrieved from http://www.waterplan.water.ca.gov/docs/cwpu2009/0310final/v1_all_cwp2009.pdf

California Native Plant Society. (2010). The CNPS ranking system, http://www.cnps.org/cnps/rareplants/ranking.php

California Native Plant Society. (n.d.). Rare and endangered plant inventory. Retrieved from http://www.rareplants.cnps.org/simple.html

Center for Biological Diversity. (2012). Petition to list the Clear lake hitch as endangered or threatened under the endangered species act. Retrieved from http://www.fgc.ca.gov/regulations/2012/Clear\%20Lake\%20hitch\%20state\%20petition\%209-2512.pdf

City of Clearlake, CA. (2012). General plan background report. Prepared by California Polytechnic State University, San Luis Obispo.

City of Clearlake, CA. (2013). Draft 2040 General Plan. Prepared by California Polytechnic State University, San Luis Obispo.

County of Lake Department of Public Works. (2010). Clear Lake Integrated Watershed Management Plan. Retrieved from http://www.co.lake.ca.us/Assets/WaterResources/Clear+Lake+Integrated+Watershed+Manageme nt+Plan/02+CLIWMP+Title+Page.pdf

County of Lake Department of Public Works. (2004). Clear Lake Integrated Aquatic Plant Management Plan. Retrieved from http://www .co.lake.ca.us/Assets/WaterResources/Aquatic+Plant+Management+Areas/Aquatic+Pl ant+Management+Plan.pdf

NatureServe. (2013). NatureServe Explorer. Retrieved from http://www.natureserve.org/explorer/servlet/NatureServe 
Post Buckley Schuh \& Jernigan. (2009). Sacramento 2030 general plan master environmental impact report city project \#M04-031, State Clearinghouse No.2007072024. Retrieved from http://www.sacgp.org/master-eir/documents/Part1_GPMasterEIR.pdf

Redbud Audubon Society of Lake County California. (2012). Retrieved from http://www.redbudaudubon.org/

The Planning Center. (2013). Newark general plan tune up draft EIR for the City of Newark: State Clearinghouse No.2013012052. Retrieved from http://www.newark.org/images/uploads/comdev/pdfs/GeneralPlan/NewarkGP_DEIR_PublicRevie w.pdf

State of California, Resources Agency. (2009). CEQA guidelines amendments. Appendix G. Retrieved from http://ceres.ca.gov/ceqa/docs/Adopted_and_Transmitted_Text_of_SB97_CEQA_Guidelines_Ame ndments.pdf

United States Environmental Protection Agency. (2013). Summary of the clean water act. Retrieved from http://www2.epa.gov/laws-regulations/summary-clean-water-act

United States Environmental Protection Agency. (2012). Summary of the resource conservation and recovery act of 1976. Retrieved from http://www.epa.gov/lawsregs/laws/rcra.html

United States Department of Interior, Fish and Wildlife Service. (2013). Endangered species act. Retrieved from http://www.fws.gov/endangered/laws-policies/

United States Department of Interior, Fish and Wildlife Service. (1998). Migratory bird treaty act of 1918. Digest of Federal Resource Laws of Interest. Retrieved from http://www.fws.gov/laws/lawsdigest/migtrea.html

United States Department of Interior, Fish and Wildlife Service. (2014). Wetlands mapper. Retrieved from http://www.fws.gov/wetlands/Wetlands-Mapper.html 


\section{Appendix 4.4-A}

Special Species Plants

\begin{tabular}{|c|c|c|c|}
\hline $\begin{array}{l}\text { Scientific } \\
\text { Name }\end{array}$ & $\begin{array}{l}\text { Common } \\
\text { Name }\end{array}$ & $\begin{array}{l}\text { Status } \\
\text { (Federal/State/CNP } \\
\text { S) }\end{array}$ & Habitat \& Blooming Period \\
\hline $\begin{array}{l}\text { Amsinckia } \\
\text { lunaris }\end{array}$ & $\begin{array}{l}\text { bent-flowered } \\
\text { fiddleneck }\end{array}$ & $(-/-/ 1 B .2)$ & $\begin{array}{l}\text { Open wooded slopes within Foothill/Cismontane } \\
\text { Woodland and Valley Grassland communities. March - } \\
\text { June. }\end{array}$ \\
\hline $\begin{array}{l}\text { Anisocarpus } \\
\text { scabridus }\end{array}$ & $\begin{array}{l}\text { scabrid alpine } \\
\text { tarplant }\end{array}$ & $(-/-/ 1 \mathrm{~B} .3)$ & $\begin{array}{l}\text { Dry, open ridges on rocky, metamorphic substrates; } \\
\text { within Red Fir Forest communities. July - August. }\end{array}$ \\
\hline $\begin{array}{l}\text { Antirrhinum } \\
\text { subcordatum }\end{array}$ & $\begin{array}{l}\text { dimorphic } \\
\text { snapdragon }\end{array}$ & $(-/-/ 4.3)$ & Chaparral, lower montane coniferous forest. April - July. \\
\hline $\begin{array}{l}\text { Antirrhinum } \\
\text { virga }\end{array}$ & $\begin{array}{l}\text { twig-like } \\
\text { snapdragon }\end{array}$ & $(-/-/ 4.3)$ & $\begin{array}{l}\text { Rocky, openings, often serpentinite; Chaparral, lower } \\
\text { montane coniferous forest. June - July. }\end{array}$ \\
\hline $\begin{array}{l}\text { Arabis } \\
\text { blepharophylla }\end{array}$ & $\begin{array}{l}\text { coast } \\
\text { rockcress }\end{array}$ & $(-/-/ 4.3)$ & $\begin{array}{l}\text { Broadleafed upland forest, Coastal scrub, Coastal prairie, } \\
\text { Coastal bluff scrub. February - May. }\end{array}$ \\
\hline $\begin{array}{l}\text { Arctostaphylos } \\
\text { canescens ssp. } \\
\text { sonomensis }\end{array}$ & $\begin{array}{l}\text { Sonoma } \\
\text { canescent } \\
\text { manzanita }\end{array}$ & $(-/-/ 1 B .2)$ & $\begin{array}{l}\text { Chaparral, lower montane coniferous forest, Cismontane } \\
\text { woodland. March - July. }\end{array}$ \\
\hline $\begin{array}{l}\text { Arctostaphylos } \\
\text { manzanita ssp. } \\
\text { elegans }\end{array}$ & $\begin{array}{l}\text { Konocti } \\
\text { manzanita }\end{array}$ & $(-/-/ 1 \mathrm{~B} .3)$ & $\begin{array}{l}\text { Chaparral, lower montane coniferous forest. January - } \\
\text { June. }\end{array}$ \\
\hline $\begin{array}{l}\text { Arctostaphylos } \\
\text { stanfordiana } \\
\text { ssp.raichei }\end{array}$ & $\begin{array}{l}\text { Raiche's } \\
\text { manzanita }\end{array}$ & $(-/-/ 1 \mathrm{~B} .1)$ & $\begin{array}{l}\text { Rocky, often serpentinite. Chaparral, lower montane } \\
\text { coniferous forest. February - April. }\end{array}$ \\
\hline $\begin{array}{l}\text { Asclepias } \\
\text { solanoana }\end{array}$ & $\begin{array}{l}\text { serpentine } \\
\text { milkweed }\end{array}$ & $(-/-/ 4.2)$ & $\begin{array}{l}\text { Chaparral, Cismontane woodland, Lower montane } \\
\text { coniferous forest. May - August. }\end{array}$ \\
\hline $\begin{array}{l}\text { Astragalus } \\
\text { breweri }\end{array}$ & $\begin{array}{l}\text { Brewer's } \\
\text { milk-vetch }\end{array}$ & $(-/-/ 4.2)$ & $\begin{array}{l}\text { Chaparral, Cismontane woodland, Meadows and seeps, } \\
\text { Valley and foothill grassland. April - June. }\end{array}$ \\
\hline $\begin{array}{l}\text { Astragalus } \\
\text { clevelandii }\end{array}$ & $\begin{array}{l}\text { Cleveland's } \\
\text { milk-vetch }\end{array}$ & $(-/-/ 4.3)$ & $\begin{array}{l}\text { Chaparral, Cismontane woodland, Riparian forest. June - } \\
\text { September. }\end{array}$ \\
\hline $\begin{array}{l}\text { Astragalus } \\
\text { rattanii var. } \\
\text { jepsonianus }\end{array}$ & $\begin{array}{l}\text { Jepson's } \\
\text { milk-vetch }\end{array}$ & $(-/-/ 1 \mathrm{~B} .2)$ & $\begin{array}{l}\text { Chaparral, Cismontane woodland, Valley and foothill } \\
\text { grassland. March - June. }\end{array}$ \\
\hline $\begin{array}{l}\text { Azolla } \\
\text { microphylla }\end{array}$ & $\begin{array}{l}\text { Mexican } \\
\text { mosquito fern }\end{array}$ & $(-/-/ 4.2)$ & Marshes and swamps (ponds, slow water). August. \\
\hline
\end{tabular}




\begin{tabular}{|c|c|c|c|}
\hline $\begin{array}{l}\text { Balsamorhiza } \\
\text { macrolepis }\end{array}$ & $\begin{array}{l}\text { big-scale } \\
\text { balsamroot }\end{array}$ & $(-/-/ 1 \mathrm{~B} .2)$ & $\begin{array}{l}\text { Chaparral, Cismontane woodland, Valley and foothill } \\
\text { grassland. March - June. }\end{array}$ \\
\hline $\begin{array}{l}\text { Boechera } \\
\text { ultraalsa }\end{array}$ & $\begin{array}{l}\text { Snow } \\
\text { Mountain } \\
\text { rockcress }\end{array}$ & $(-/-/ 1 \mathrm{~B} .1)$ & Upper montane coniferous forest (rocky). $n / a$ \\
\hline $\begin{array}{l}\text { Brasenia } \\
\text { schreberi }\end{array}$ & watershield & $(-/-/ 2 B .3)$ & Marshes and swamps /freshwater. June - September. \\
\hline $\begin{array}{l}\text { Brodiaea } \\
\text { leptandra }\end{array}$ & $\begin{array}{l}\text { narrow- } \\
\text { anthered } \\
\text { brodiaea }\end{array}$ & $(-/-/ 1 B .2)$ & $\begin{array}{l}\text { Broadleafed upland forest, Chaparral, Cismontane } \\
\text { woodland, Lower montane coniferous forest, Valley and } \\
\text { foothill grassland. May - July. }\end{array}$ \\
\hline $\begin{array}{l}\text { Brodiaea } \\
\text { rosea }\end{array}$ & $\begin{array}{l}\text { Indian Valley } \\
\text { brodiaea }\end{array}$ & (-/Endangered/1B.1) & $\begin{array}{l}\text { Closed-cone coniferous forest, Chaparral, Cismontane } \\
\text { woodland, Valley and foothill grassland. May - June. }\end{array}$ \\
\hline $\begin{array}{l}\text { Calamagrostis } \\
\text { ophitidis }\end{array}$ & $\begin{array}{l}\text { serpentine } \\
\text { reed grass }\end{array}$ & $(-/-/ 4.3)$ & $\begin{array}{l}\text { Serpentinite, rocky; Chaparral (open, often north-facing } \\
\text { slopes), Lower montane coniferous forest, Meadows and } \\
\text { seeps, Valley and foothill grassland. April - July. }\end{array}$ \\
\hline $\begin{array}{l}\text { California } \\
\text { macrophylla }\end{array}$ & $\begin{array}{l}\text { round-leaved } \\
\text { filaree }\end{array}$ & $(-/-/ 1 \mathrm{~B} .1)$ & $\begin{array}{l}\text { Clay; Cismontane woodland, Valley and foothill } \\
\text { grassland. March - May. }\end{array}$ \\
\hline $\begin{array}{l}\text { Calochortus } \\
\text { uniflorus }\end{array}$ & pink star-tulip & $(-/ / / 4.2)$ & $\begin{array}{l}\text { Coastal prairie, Coastal scrub, meadows and seeps, North } \\
\text { Coast coniferous forest. April - June. }\end{array}$ \\
\hline $\begin{array}{l}\text { Calycadenia } \\
\text { micrantha }\end{array}$ & $\begin{array}{l}\text { small- } \\
\text { flowered } \\
\text { calycadenia }\end{array}$ & $(-/-/ 1 B .2)$ & $\begin{array}{l}\text { Roadsides, rocky, talus, scree, sometimes serpentinite, } \\
\text { sparsely vegetated areas. June - September. }\end{array}$ \\
\hline $\begin{array}{l}\text { Calyptridium } \\
\text { quadripetalum }\end{array}$ & $\begin{array}{l}\text { four-petaled } \\
\text { pussypaws }\end{array}$ & $(-/-/ 4.3)$ & $\begin{array}{l}\text { Chaparral; sandy or gravelly, usually serpentinite. April - } \\
\text { June. }\end{array}$ \\
\hline $\begin{array}{l}\text { Calystegia } \\
\text { collina ssp. } \\
\text { oxyphylla }\end{array}$ & $\begin{array}{l}\text { Mt. Saint } \\
\text { Helena } \\
\text { morning- } \\
\text { glory }\end{array}$ & $(-/ / / 4.2)$ & $\begin{array}{l}\text { Chaparral, Lower montane coniferous forest, Valley and } \\
\text { foothill grassland. April - June. }\end{array}$ \\
\hline $\begin{array}{l}\text { Calystegia } \\
\text { collina ssp. } \\
\text { tridactylosa }\end{array}$ & $\begin{array}{l}\text { coast range } \\
\text { bindweed }\end{array}$ & $(-/-/ 1 \mathrm{~B} .2)$ & $\begin{array}{l}\text { Serpentinite, rocky, gravelly, openings; Chaparral, } \\
\text { Cismontane woodland. April - June. }\end{array}$ \\
\hline $\begin{array}{l}\text { Calystegia } \\
\text { purpurata ssp. } \\
\text { saxicola }\end{array}$ & $\begin{array}{l}\text { coastal bluff } \\
\text { morning- } \\
\text { glory }\end{array}$ & $(-/-/ 1 \mathrm{~B} .2)$ & $\begin{array}{l}\text { Coastal bluff scrub, Coastal dunes, Coastal scrub, North } \\
\text { Coast coniferous forest. March - September. }\end{array}$ \\
\hline Carex comosa & bristly sedge & $(-/-/ 2 B .1)$ & $\begin{array}{l}\text { Coastal prairie, Marshes and swamps (lake margins), } \\
\text { Valley and foothill grassland. May - September. }\end{array}$ \\
\hline Carex & porcupine & $(-/-/ 2 \mathrm{~B} .1)$ & Marshes and swamps (streambanks). May - September. \\
\hline
\end{tabular}




\begin{tabular}{|c|c|c|c|}
\hline hystericina & sedge & & \\
\hline $\begin{array}{l}\text { Carex } \\
\text { klamathensis }\end{array}$ & $\begin{array}{l}\text { Klamath } \\
\text { sedge }\end{array}$ & $(-/-/ 1 B .2)$ & $\begin{array}{l}\text { Chaparral, Cismontane woodland, Meadows and seeps. } \\
\text { n/a }\end{array}$ \\
\hline $\begin{array}{l}\text { Castilleja } \\
\text { rubicundula }\end{array}$ & & & \\
\hline $\begin{array}{l}\text { var. } \\
\text { rubicundula }\end{array}$ & $\begin{array}{l}\text { pink } \\
\text { creamsacs }\end{array}$ & $(-/-/ 1 B .2)$ & $\begin{array}{l}\text { Chaparral (openings), Cismontane woodland, Meadows } \\
\text { and seeps, Valley and foothill grassland. April - June. }\end{array}$ \\
\hline $\begin{array}{l}\text { Ceanothus } \\
\text { confusus }\end{array}$ & $\begin{array}{l}\text { Rincon Ridge } \\
\text { ceanothus }\end{array}$ & $(-/-/ 1 \mathrm{~B} .1)$ & $\begin{array}{l}\text { Closed-cone coniferous forest, Chaparral, Cismontane } \\
\text { woodland. February - June. }\end{array}$ \\
\hline $\begin{array}{l}\text { Ceanothus } \\
\text { divergens }\end{array}$ & $\begin{array}{l}\text { Calistoga } \\
\text { ceanothus }\end{array}$ & $(-/-/ 1 B .2)$ & $\begin{array}{l}\text { Chaparral (serpentinite or volcanic, rocky). February - } \\
\text { April. }\end{array}$ \\
\hline $\begin{array}{l}\text { Centromadia } \\
\text { parryi ssp. } \\
\text { parryi }\end{array}$ & $\begin{array}{l}\text { pappose } \\
\text { tarplant }\end{array}$ & $(-/-/ 1 B .2)$ & $\begin{array}{l}\text { Chaparral, Coastal prairie, Meadows and seeps, Marshes } \\
\text { and swamps (coastal salt), Valley and foothill grassland } \\
\text { (vernally mesic). May - November }\end{array}$ \\
\hline $\begin{array}{l}\text { Chlorogalum } \\
\text { pomeridianum } \\
\text { var.minus }\end{array}$ & $\begin{array}{l}\text { dwarf } \\
\text { soaproot }\end{array}$ & $(-/-/ 1 \mathrm{~B} .2)$ & Chaparral (serpentinite). May - August. \\
\hline $\begin{array}{l}\text { Clarkia } \\
\text { gracilis ssp. } \\
\text { tracyi }\end{array}$ & $\begin{array}{l}\text { Tracy's } \\
\text { clarkia }\end{array}$ & $(-/-/ 4.2)$ & Chaparral (openings, usually serpentinite). April - July. \\
\hline $\begin{array}{l}\text { Collomia } \\
\text { diversifolia }\end{array}$ & $\begin{array}{l}\text { serpentine } \\
\text { collomia }\end{array}$ & $(-/ / / 4.3)$ & Chaparral, Cismontane woodland. May - June. \\
\hline $\begin{array}{l}\text { Cordylanthus } \\
\text { tenuis ssp. } \\
\text { brunneus }\end{array}$ & $\begin{array}{l}\text { serpentine } \\
\text { bird's-beak }\end{array}$ & $(-/ / / 4.3)$ & $\begin{array}{l}\text { Closed-cone coniferous forest, Chaparral, Cismontane } \\
\text { woodland. July - August. }\end{array}$ \\
\hline $\begin{array}{l}\text { Cryptantha } \\
\text { dissita }\end{array}$ & $\begin{array}{l}\text { serpentine } \\
\text { cryptantha }\end{array}$ & $(-/-/ 1 \mathrm{~B} .2)$ & Chaparral (serpentinite). April - June. \\
\hline $\begin{array}{l}\text { Cuscuta } \\
\text { jepsonii }\end{array}$ & $\begin{array}{l}\text { Jepson's } \\
\text { dodder }\end{array}$ & $(-/-/ 1 B .2)$ & North Coast coniferous forest. July - September. \\
\hline $\begin{array}{l}\text { Delphinium } \\
\text { uliginosum }\end{array}$ & $\begin{array}{l}\text { swamp } \\
\text { larkspur }\end{array}$ & $(-/-/ 4.2)$ & Chaparral, Valley and foothill grassland. May - June. \\
\hline $\begin{array}{l}\text { Didymodon } \\
\text { norrisii }\end{array}$ & $\begin{array}{l}\text { Norris' beard } \\
\text { moss }\end{array}$ & $(-/-/ 2 \mathrm{~B} .2)$ & $\begin{array}{l}\text { Cismontane woodland, Lower montane coniferous forest. } \\
\mathrm{n} / \mathrm{a}\end{array}$ \\
\hline $\begin{array}{l}\text { Epilobium } \\
\text { nivium }\end{array}$ & $\begin{array}{l}\text { Snow } \\
\text { Mountain } \\
\text { willowherb }\end{array}$ & $(-/-/ 1 \mathrm{~B} .2)$ & $\begin{array}{l}\text { Chaparral, Upper montane coniferous forest. June - } \\
\text { October. }\end{array}$ \\
\hline
\end{tabular}




\begin{tabular}{|c|c|c|c|}
\hline $\begin{array}{l}\text { Eriastrum } \\
\text { brandegeeae }\end{array}$ & $\begin{array}{l}\text { Brandegee's } \\
\text { eriastrum }\end{array}$ & $(-/-/ 1 \mathrm{~B} .1)$ & Chaparral, Cismontane woodland. April - August. \\
\hline $\begin{array}{l}\text { Eriastrum } \\
\text { tracyi }\end{array}$ & $\begin{array}{l}\text { Tracy's } \\
\text { eriastrum }\end{array}$ & $(-/$ Rare/3.2) & Chaparral, Cismontane woodland. May - July. \\
\hline $\begin{array}{l}\text { Erigeron } \\
\text { greenei }\end{array}$ & $\begin{array}{l}\text { Greene's } \\
\text { narrow- } \\
\text { leaved daisy }\end{array}$ & $(-/-/ 1 B .2)$ & Chaparral (serpentinite or volcanic). May - September. \\
\hline $\begin{array}{l}\text { Eriogonum } \\
\text { nervulosum }\end{array}$ & $\begin{array}{l}\text { Snow } \\
\text { Mountain } \\
\text { buckwheat }\end{array}$ & $(-/-/ 1 \mathrm{~B} .2)$ & Chaparral (serpentinite). June - September. \\
\hline $\begin{array}{l}\text { Eryngium } \\
\text { constancei }\end{array}$ & $\begin{array}{l}\text { Loch } \\
\text { Lomond } \\
\text { button-celery }\end{array}$ & $\begin{array}{l}\text { (Endangered/Endan } \\
\text { gered/1B.1) }\end{array}$ & Vernal pools. April - June. \\
\hline $\begin{array}{l}\text { Fritillaria } \\
\text { pluriflora }\end{array}$ & adobe-lily & $(-/-/ 1 B .2)$ & $\begin{array}{l}\text { Chaparral, Cismontane woodland, Valley and foothill } \\
\text { grassland. February - April. }\end{array}$ \\
\hline $\begin{array}{l}\text { Gratiola } \\
\text { heterosepala }\end{array}$ & $\begin{array}{l}\text { Boggs Lake } \\
\text { hedge-hyssop }\end{array}$ & (-/Endangered/1B.2) & $\begin{array}{l}\text { Marshes and swamps (lake margins), Vernal pools. April } \\
\text { - August. }\end{array}$ \\
\hline $\begin{array}{l}\text { Harmonia } \\
\text { hallii }\end{array}$ & $\begin{array}{l}\text { Hall's } \\
\text { harmonia }\end{array}$ & $(-/ / / 1 \mathrm{~B} .2)$ & Chaparral (serpentinite). April - June. \\
\hline $\begin{array}{l}\text { Hesperolinon } \\
\text { adenophyllum }\end{array}$ & $\begin{array}{l}\text { glandular } \\
\text { western flax }\end{array}$ & $(-/-/ 1 \mathrm{~B} .2)$ & $\begin{array}{l}\text { Chaparral, Cismontane woodland, Valley and foothill } \\
\text { grassland. May - August. }\end{array}$ \\
\hline $\begin{array}{l}\text { Hesperolinon } \\
\text { bicarpellatum }\end{array}$ & $\begin{array}{l}\text { two- } \\
\text { carpellate } \\
\text { western flax }\end{array}$ & $(-/-/ 1 \mathrm{~B} .2)$ & Chaparral (serpentinite). May - July. \\
\hline $\begin{array}{l}\text { Hesperolinon } \\
\text { didymocarpum }\end{array}$ & $\begin{array}{l}\text { Lake County } \\
\text { western flax }\end{array}$ & (-/Endangered/1B.2) & $\begin{array}{l}\text { Chaparral, Cismontane woodland, Valley and foothill } \\
\text { grassland. May - July. }\end{array}$ \\
\hline $\begin{array}{l}\text { Hesperolinon } \\
\text { drymarioides }\end{array}$ & $\begin{array}{l}\text { drymaria-like } \\
\text { western flax }\end{array}$ & $(-/-/ 1 \mathrm{~B} .2)$ & $\begin{array}{l}\text { Closed-cone coniferous forest, Chaparral, Cismontane } \\
\text { woodland, Valley and foothill grassland. May - August. }\end{array}$ \\
\hline $\begin{array}{l}\text { Hesperolinon } \\
\text { tehamense }\end{array}$ & $\begin{array}{l}\text { Tehama } \\
\text { County } \\
\text { western flax }\end{array}$ & $(-/-/ 1 B .3)$ & Chaparral, Cismontane woodland. May - July. \\
\hline $\begin{array}{l}\text { Horkelia } \\
\text { bolanderi }\end{array}$ & $\begin{array}{l}\text { Bolander's } \\
\text { horkelia }\end{array}$ & $(-/-/ 1 \mathrm{~B} .2)$ & $\begin{array}{l}\text { Chaparral, Lower montane coniferous forest, Meadows } \\
\text { and seeps, Valley and foothill grassland. June - August. }\end{array}$ \\
\hline $\begin{array}{l}\text { Imperata } \\
\text { brevifolia }\end{array}$ & $\begin{array}{l}\text { California } \\
\text { satintail }\end{array}$ & $(-/-/ 2 \mathrm{~B} .1)$ & $\begin{array}{l}\text { Riparian scrub, Meadows and seeps (often alkali), } \\
\text { Mojavean desert scrub, Coastal scrub, Chaparral. } \\
\text { September - May. }\end{array}$ \\
\hline
\end{tabular}




\begin{tabular}{|c|c|c|c|}
\hline Juglans hindsii & $\begin{array}{l}\text { Northern } \\
\text { California } \\
\text { black walnut }\end{array}$ & $(-/-/ 1 \mathrm{~B} .1)$ & Riparian forest, woodland. April - May. \\
\hline $\begin{array}{l}\text { Lasthenia } \\
\text { burkei }\end{array}$ & $\begin{array}{l}\text { Burke's } \\
\text { goldfields }\end{array}$ & $\begin{array}{l}\text { (Endangered/Endan } \\
\text { gered/1B.1) }\end{array}$ & Vernal pools, Meadows and seeps (mesic). April - June. \\
\hline $\begin{array}{l}\text { Layia } \\
\text { septentrionalis }\end{array}$ & Colusa layia & $(-/-/ 1 B .2)$ & $\begin{array}{l}\text { Chaparral, Cismontane woodland, Valley and foothill } \\
\text { grassland. April - May. }\end{array}$ \\
\hline $\begin{array}{l}\text { Legenere } \\
\text { limosa }\end{array}$ & legenere & $(-/-/ 1 \mathrm{~B} .1)$ & Vernal pools. April - June. \\
\hline $\begin{array}{l}\text { Leptosiphon } \\
\text { acicularis }\end{array}$ & $\begin{array}{l}\text { bristly } \\
\text { leptosiphon }\end{array}$ & $(-/-/ 4.2)$ & $\begin{array}{l}\text { Valley and foothill grassland, Coastal prairie, Cismontane } \\
\text { woodland, Chaparral. April - July. }\end{array}$ \\
\hline $\begin{array}{l}\text { Leptosiphon } \\
\text { jepsonii }\end{array}$ & $\begin{array}{l}\text { Jepson's } \\
\text { leptosiphon }\end{array}$ & $(-/-/ 1 B .2)$ & Chaparral, Cismontane woodland. March - May. \\
\hline $\begin{array}{l}\text { Limnanthes } \\
\text { floccosa ssp. } \\
\text { floccosa }\end{array}$ & $\begin{array}{l}\text { woolly } \\
\text { meadowfoam }\end{array}$ & $(-/-/ 4.2)$ & $\begin{array}{l}\text { Vernal pools, Valley and foothill grassland, Cismontane } \\
\text { woodland, Chaparral. March - June. }\end{array}$ \\
\hline $\begin{array}{l}\text { Lomatium } \\
\text { repostum }\end{array}$ & $\begin{array}{l}\text { Napa } \\
\text { lomatium }\end{array}$ & $(-/-/ 4.3)$ & Chaparral, Cismontane woodland. March - June. \\
\hline $\begin{array}{l}\text { Lupinus } \\
\text { antoninus }\end{array}$ & $\begin{array}{l}\text { Anthony } \\
\text { Peak lupine }\end{array}$ & $(-/-/ 1 B .3)$ & Lower \& upper montane coniferous forest. May - July. \\
\hline $\begin{array}{l}\text { Lupinus } \\
\text { sericatus }\end{array}$ & $\begin{array}{l}\text { Cobb } \\
\text { Mountain } \\
\text { lupine }\end{array}$ & $(-/-/ 1 B .2)$ & $\begin{array}{l}\text { Broadleafed upland forest, Chaparral, Cismontane } \\
\text { woodland, Lower montane coniferous forest. March - } \\
\text { June. }\end{array}$ \\
\hline $\begin{array}{l}\text { Malacothamnu } \\
\text { s hallii }\end{array}$ & $\begin{array}{l}\text { Hall's bush- } \\
\text { mallow }\end{array}$ & $(-/-/ 1 B .2)$ & Chaparral, Coastal scrub. May - October. \\
\hline $\begin{array}{l}\text { Micropus } \\
\text { amphibolus }\end{array}$ & $\begin{array}{l}\text { Mt. Diablo } \\
\text { cottonweed }\end{array}$ & $(-/-/ 3.2)$ & $\begin{array}{l}\text { Broadleafed upland forest, Chaparral, Cismontane } \\
\text { woodland, Valley and foothill grassland. March - May. }\end{array}$ \\
\hline $\begin{array}{l}\text { Mielichhoferia } \\
\text { elongata }\end{array}$ & $\begin{array}{l}\text { elongate } \\
\text { copper moss }\end{array}$ & $(-/-/ 2 B .2)$ & $\begin{array}{l}\text { Cismontane woodland (metamorphic, rock, usually } \\
\text { vernally mesic). n/a }\end{array}$ \\
\hline $\begin{array}{l}\text { Myosurus } \\
\text { minimus ssp. } \\
\text { apus }\end{array}$ & $\begin{array}{l}\text { little } \\
\text { mousetail }\end{array}$ & $(-/-/ 3.1)$ & $\begin{array}{l}\text { Valley and foothill grassland, Vernal pools (alkaline). } \\
\text { March - June. }\end{array}$ \\
\hline $\begin{array}{l}\text { Navarretia } \\
\text { cotulifolia }\end{array}$ & $\begin{array}{l}\text { cotula } \\
\text { navarretia }\end{array}$ & $(-/-/ 4.2)$ & $\begin{array}{l}\text { Chaparral, Cismontance woodland, Valley and foothill } \\
\text { grassland. May-June. }\end{array}$ \\
\hline $\begin{array}{l}\text { Navarretia } \\
\text { jepsonii }\end{array}$ & $\begin{array}{l}\text { Jepson's } \\
\text { navarretia }\end{array}$ & $(-/-/ 4.3)$ & $\begin{array}{l}\text { Chaparral, Cismontane woodland, Valley and foothill } \\
\text { grassland. April - June. }\end{array}$ \\
\hline
\end{tabular}




\begin{tabular}{|c|c|c|c|}
\hline $\begin{array}{l}\text { Navarretia } \\
\text { leucocephala } \\
\text { ssp. Bakeri }\end{array}$ & $\begin{array}{l}\text { Baker's } \\
\text { navarretia }\end{array}$ & $(-/-/ 1 \mathrm{~B} .1)$ & $\begin{array}{l}\text { Vernal pools, Cismontane woodland, Lower montane } \\
\text { coniferous forest, Meadows and seeps, Valley and foothill } \\
\text { grasslands, Vernal pools. April- July. }\end{array}$ \\
\hline $\begin{array}{l}\text { Navarretia } \\
\text { leucocephala } \\
\text { ssp. pauciflora }\end{array}$ & $\begin{array}{l}\text { few-flowered } \\
\text { navarretia }\end{array}$ & $\begin{array}{l}\text { (Endangered/Threat } \\
\text { ened/1B.1) }\end{array}$ & Vernal pools (volcanic ash flow). May - June. \\
\hline $\begin{array}{l}\text { Navarretia } \\
\text { leucocephala } \\
\text { ssp.plieantha }\end{array}$ & $\begin{array}{l}\text { many- } \\
\text { flowered } \\
\text { navarretia }\end{array}$ & $\begin{array}{l}\text { (Endangered/Threat } \\
\text { ened/1B.2) }\end{array}$ & Vernal pools (volcanic ash flow). May - June. \\
\hline $\begin{array}{l}\text { Navarretia } \\
\text { myersii ssp. } \\
\text { deminuta }\end{array}$ & $\begin{array}{l}\text { small } \\
\text { pincushion } \\
\text { navarretia }\end{array}$ & $(-/-/ 1 \mathrm{~B} .1)$ & Vernal pools (clay loam). April - May. \\
\hline Orcuttia tenuis & $\begin{array}{l}\text { slender } \\
\text { Orcutt grass }\end{array}$ & $\begin{array}{l}\text { (Threatened/Endang } \\
\text { ered/1B.1) }\end{array}$ & Vernal pools. May - October. \\
\hline $\begin{array}{l}\text { Penstemon } \\
\text { newberryi var. } \\
\text { sonomensis }\end{array}$ & $\begin{array}{l}\text { Sonoma } \\
\text { beardtongue }\end{array}$ & $(-/-/ 1 B .3)$ & Chaparral (rocky). April - August. \\
\hline $\begin{array}{l}\text { Piperia } \\
\text { michaelii }\end{array}$ & $\begin{array}{l}\text { Michael's rein } \\
\text { orchid }\end{array}$ & $(-/-/ 4.2)$ & $\begin{array}{l}\text { Coastal bluff scrub, Closed-cone coniferous forest, } \\
\text { Chaparral, Cismontane woodland, coastal scrub, lower } \\
\text { montane coniferous forest. April - August. }\end{array}$ \\
\hline $\begin{array}{l}\text { Plagiobothrys } \\
\text { lithocaryus }\end{array}$ & $\begin{array}{l}\text { Mayacamas } \\
\text { popcornflowe } \\
\mathrm{r}\end{array}$ & $(-/-/ 1 \mathrm{a})$ & $\begin{array}{l}\text { Chaparral, Cismontane woodland, Valley and foothill } \\
\text { grassland. April - May. }\end{array}$ \\
\hline $\begin{array}{l}\text { Potamogeton } \\
\text { zosteriformis }\end{array}$ & $\begin{array}{l}\text { eel-grass } \\
\text { pondweed }\end{array}$ & $(-/-/ 2 \mathrm{~B} .2)$ & Marshes and swamps (assorted freshwater). June - July. \\
\hline $\begin{array}{l}\text { Sedella } \\
\text { leiocarpa }\end{array}$ & $\begin{array}{l}\text { Lake County } \\
\text { stonecrop }\end{array}$ & $\begin{array}{l}\text { (Endangered/Endan } \\
\text { gered/1B.1) }\end{array}$ & $\begin{array}{l}\text { Vernal pools, Valley and foothill grassland, Cismontane } \\
\text { woodland, April - May. }\end{array}$ \\
\hline $\begin{array}{l}\text { Sidalcea } \\
\text { hickmanii ssp. } \\
\text { pillsburiensis }\end{array}$ & $\begin{array}{l}\text { Lake } \\
\text { Pillsbury } \\
\text { checkerbloom }\end{array}$ & $(-/-/ 1 \mathrm{~B} .2)$ & Franciscan soils, Chaparral. July - August. \\
\hline $\begin{array}{l}\text { Sidalcea } \\
\text { oregana ssp. } \\
\text { Hydrophila }\end{array}$ & $\begin{array}{l}\text { marsh } \\
\text { checkerbloom }\end{array}$ & $(-/-/ 1 B .2)$ & Meadows and seeps, Riparian forest. July - August. \\
\hline $\begin{array}{l}\text { Streptanthus } \\
\text { barbiger }\end{array}$ & $\begin{array}{l}\text { bearded } \\
\text { jewel-flower }\end{array}$ & $(-/-/ 4.2)$ & Chaparral (serpentinite). May - July. \\
\hline $\begin{array}{l}\text { Streptanthus } \\
\text { brachiatus ssp. } \\
\text { brachiatus }\end{array}$ & $\begin{array}{l}\text { Socrates } \\
\text { Mine jewel- } \\
\text { flower }\end{array}$ & $(-/ / / 1 \mathrm{~B} .2)$ & Closed-cone coniferous forest, Chaparral. May - June. \\
\hline
\end{tabular}




\begin{tabular}{|c|c|c|c|}
\hline $\begin{array}{l}\text { Streptanthus } \\
\text { hesperidis }\end{array}$ & $\begin{array}{l}\text { green jewel- } \\
\text { flower }\end{array}$ & $(-/-/ 1 B .2)$ & Chaparral, Cismontane woodland. May - July. \\
\hline $\begin{array}{l}\text { Streptanthus } \\
\text { vernalis }\end{array}$ & $\begin{array}{l}\text { early jewel- } \\
\text { flower }\end{array}$ & $(-/-/ 1 B .2)$ & Closed-cone coniferous forest, Chaparral. March - May. \\
\hline $\begin{array}{l}\text { Tortella } \\
\text { alpicola }\end{array}$ & $\begin{array}{l}\text { alpine crisp } \\
\text { moss }\end{array}$ & $(-/-/ 2 B .3)$ & Cismontane woodland (volcanic, rock). n/a \\
\hline $\begin{array}{l}\text { Toxicoscordio } \\
\text { nfontanum }\end{array}$ & $\begin{array}{l}\text { marsh } \\
\text { zigadenus }\end{array}$ & $(-/-/ 4.2)$ & $\begin{array}{l}\text { Chaparral, Cismontane woodland, Lower montane } \\
\text { coniferous forest, Meadows and seeps, Marshes and } \\
\text { swamps. April - July. }\end{array}$ \\
\hline $\begin{array}{l}\text { Tracyina } \\
\text { rostrata }\end{array}$ & $\begin{array}{l}\text { beaked } \\
\text { tracyina }\end{array}$ & $(-/-/ 1 B .2)$ & $\begin{array}{l}\text { Cismontane woodland, Valley and foothill grassland. May } \\
\text { - June. }\end{array}$ \\
\hline $\begin{array}{l}\text { Trichodon } \\
\text { cylindricus }\end{array}$ & $\begin{array}{l}\text { cylindrical } \\
\text { trichodon }\end{array}$ & $(-/-/ 2 \mathrm{~B} .2)$ & $\begin{array}{l}\text { Broadleafed upland forest, Meadows and seeps, Upper } \\
\text { montane coniferous forest. } \mathrm{n} / \mathrm{a}\end{array}$ \\
\hline $\begin{array}{l}\text { Trichostema } \\
\text { ruygtii }\end{array}$ & $\begin{array}{l}\text { Napa } \\
\text { bluecurls }\end{array}$ & $(-/-/ 1 \mathrm{~B} .2)$ & $\begin{array}{l}\text { Chaparral, Cismontane woodland, Lower montane } \\
\text { coniferous forest, Valley and foothill grassland, vernal } \\
\text { pools. June - October. }\end{array}$ \\
\hline $\begin{array}{l}\text { Trifolium } \\
\text { hydrophilum }\end{array}$ & saline clover & $(-/-/ 1 B .2)$ & $\begin{array}{l}\text { Marshes and swamps, Valley and foothill grassland } \\
\text { (mesic, alkaline), Vernal pools. April - June. }\end{array}$ \\
\hline $\begin{array}{l}\text { Viburnum } \\
\text { ellipticum }\end{array}$ & $\begin{array}{l}\text { oval-leaved } \\
\text { viburnum }\end{array}$ & $(-/-/ 2 \mathrm{~B} .3)$ & $\begin{array}{l}\text { Chaparral, Cismontane woodland, Lower montane } \\
\text { coniferous forest. May - June. }\end{array}$ \\
\hline
\end{tabular}

Source: California Department of Fish and Wildlife, 2013 and California Native Plant Society, 2013.

\section{Appendix 4.4-B}

Special Species Animals

\begin{tabular}{llll}
\hline $\begin{array}{l}\text { Scientific } \\
\text { Name }\end{array}$ & Common Name & $\begin{array}{l}\text { Status (Federal/State/ } \\
\text { Species of Special } \\
\text { Concern) }\end{array}$ & Habitat \\
\hline $\begin{array}{l}\text { Accipiter } \\
\text { gentilis }\end{array}$ & $\begin{array}{l}\text { northern } \\
\text { goshawk }\end{array}$ & $(-/ /$ SSC) & Deciduous, coniferous, and mixed forests. \\
$\begin{array}{l}\text { Agelaius } \\
\text { tricolor }\end{array}$ & tricolored & $(-/ /$ SSC $)$ & $\begin{array}{l}\text { Marshes, thickets, open cultivated lands and } \\
\text { pastures. }\end{array}$ \\
$\begin{array}{l}\text { Antrozous } \\
\text { pallidus }\end{array}$ & pallid bat & $(-/-/ S S C)$ & $\begin{array}{l}\text { Arid deserts and grasslands, often near rocky } \\
\text { outcrops and water. }\end{array}$ \\
$\begin{array}{l}\text { Aquila } \\
\text { chrysaetos }\end{array}$ & golden eagle & $(-/-/ F P / W L)$ & Open and semi-open country. \\
\hline
\end{tabular}




\begin{tabular}{|c|c|c|c|}
\hline $\begin{array}{l}\text { Archoplites } \\
\text { interruptus }\end{array}$ & $\begin{array}{l}\text { Sacramento } \\
\text { perch }\end{array}$ & $(-/-/ S S C)$ & $\begin{array}{l}\text { Lacustrine habitats, especially in warm, turbid, } \\
\text { moderately alkaline reservoirs or farm ponds. }\end{array}$ \\
\hline $\begin{array}{l}\text { Artemisiospiz } \\
\text { a belli }\end{array}$ & $\begin{array}{l}\text { Bell's sage } \\
\text { sparrow }\end{array}$ & (-/-/WL) & $\begin{array}{l}\text { Chaparral especially by chamise and/or } \\
\text { California sagebrush dominated areas. }\end{array}$ \\
\hline $\begin{array}{l}\text { Coccyzus } \\
\text { americanus } \\
\text { occidentalis }\end{array}$ & $\begin{array}{l}\text { western yellow- } \\
\text { billed cuckoo }\end{array}$ & (Candidate/Endangered/- & Deciduous riparian woodland. \\
\hline $\begin{array}{l}\text { Corynorhinus } \\
\text { townsendii }\end{array}$ & $\begin{array}{l}\text { Townsend's big- } \\
\text { eared bat }\end{array}$ & (-/Candidate/SSC) & $\begin{array}{l}\text { Forested regions and buildings, and in areas with } \\
\text { a mosaic of woodland, grassland, and/or } \\
\text { shrubland. }\end{array}$ \\
\hline $\begin{array}{l}\text { Desmocerus } \\
\text { californicus } \\
\text { dimorphus }\end{array}$ & $\begin{array}{l}\text { valley } \\
\text { elderberry } \\
\text { longhorn beetle }\end{array}$ & (Threatened/-/-) & Riparian wooded areas. \\
\hline $\begin{array}{l}\text { Emys } \\
\text { marmorata }\end{array}$ & $\begin{array}{l}\text { western pond } \\
\text { turtle }\end{array}$ & $(-/-/ \mathrm{SCC})$ & Riparian. \\
\hline $\begin{array}{l}\text { Falco } \\
\text { mexicanus }\end{array}$ & prairie falcon & $(-/-/ W L)$ & $\begin{array}{l}\text { Alpine, Cliff, Cropland/hedgerow, Desert, } \\
\text { Grassland/herbaceous. }\end{array}$ \\
\hline Gulo & $\begin{array}{l}\text { California } \\
\text { wolverine }\end{array}$ & (Proposed/Threatened/FP & $\begin{array}{l}\text { Alpine, Forest - Conifer, Grassland/herbaceous, } \\
\text { Shrubland/chaparral, Tundra, Woodland - } \\
\text { Conifer. }\end{array}$ \\
\hline $\begin{array}{l}\text { Haliaeetus } \\
\text { leucocephalus }\end{array}$ & bald eagle & (Delisted/Endangered/FP & $\begin{array}{l}\text { Breeding habitat most commonly close to bodies } \\
\text { of water in these habitats: conifer, hardwood, } \\
\text { mixed forests. }\end{array}$ \\
\hline $\begin{array}{l}\text { Hysterocarpu } \\
\text { s traski pomo }\end{array}$ & $\begin{array}{l}\text { Russian River } \\
\text { tule perch }\end{array}$ & $(-/-/ \mathrm{SCC})$ & Freshwater medium river, pools. \\
\hline $\begin{array}{l}\text { Lasiurus } \\
\text { blossevillii }\end{array}$ & western red bat & $(-/-/ \mathrm{SCC})$ & $\begin{array}{l}\text { Riparian habitats dominated by cottonwoods, } \\
\text { oaks, sycamores, and walnuts. }\end{array}$ \\
\hline $\begin{array}{l}\text { Lavinia } \\
\text { exilicauda chi }\end{array}$ & $\begin{array}{l}\text { Clear Lake } \\
\text { hitch }\end{array}$ & (-/Candidate/SCC) & Freshwater creek, lake. \\
\hline $\begin{array}{l}\text { Macrotus } \\
\text { californicus }\end{array}$ & $\begin{array}{l}\text { California leaf- } \\
\text { nosed bat }\end{array}$ & $(-/-/ \mathrm{SCC})$ & Lowland desert scrub. \\
\hline $\begin{array}{l}\text { Martes } \\
\text { americana } \\
\text { humboldtensis }\end{array}$ & $\begin{array}{l}\text { Humboldt } \\
\text { marten }\end{array}$ & $(-/-/ \mathrm{SCC})$ & $\begin{array}{l}\text { Old-growth, conifer-dominated forests with } \\
\text { dense shrub cover. }\end{array}$ \\
\hline $\begin{array}{l}\text { Martes } \\
\text { pennanti }\end{array}$ & $\begin{array}{l}\text { fisher - West } \\
\text { Coast DPS }\end{array}$ & $\begin{array}{l}\text { (Candidate/Candidate/SC } \\
\text { C) }\end{array}$ & $\begin{array}{l}\text { Upland and lowland forests in dense coniferous } \\
\text { or mixed forests. }\end{array}$ \\
\hline
\end{tabular}




\begin{tabular}{|c|c|c|c|}
\hline $\begin{array}{l}\text { Oncorhynchus } \\
\text { mykiss irideus }\end{array}$ & $\begin{array}{l}\text { steelhead - } \\
\text { central } \\
\text { California coast } \\
\text { DPS }\end{array}$ & (Threatened/-/-) & $\begin{array}{l}\text { Occur in the ocean, in rivers and creeks, and in } \\
\text { large inland lakes. }\end{array}$ \\
\hline $\begin{array}{l}\text { Pandion } \\
\text { haliaetus }\end{array}$ & osprey & $(-/-/ W L)$ & Along rivers, lakes, reservoirs, and seacoasts. \\
\hline $\begin{array}{l}\text { Phalacrocora } \\
x \text { auritus }\end{array}$ & $\begin{array}{l}\text { double-crested } \\
\text { cormorant }\end{array}$ & $(-/-/ W L)$ & $\begin{array}{l}\text { Lakes, ponds, rivers, lagoons, swamps, coastal } \\
\text { bays, marine islands, and seacoasts. }\end{array}$ \\
\hline Progne subis & purple martin & $(-/-/ \mathrm{SCC})$ & $\begin{array}{l}\text { Cropland/hedgerow, Desert, } \\
\text { Grassland/herbaceous, Savanna, } \\
\text { Shrubland/chaparral, Suburban/orchard, } \\
\text { Woodland - Conifer, Woodland - Hardwood }\end{array}$ \\
\hline Rana boylii & $\begin{array}{l}\text { foothill yellow- } \\
\text { legged frog }\end{array}$ & $(-/-/ \mathrm{SCC})$ & $\begin{array}{l}\text { In streams in areas of chaparral, open woodland, } \\
\text { and forest. }\end{array}$ \\
\hline $\begin{array}{l}\text { Strix } \\
\text { occidentalis } \\
\text { caurina }\end{array}$ & $\begin{array}{l}\text { northern spotted } \\
\text { owl }\end{array}$ & (Threatened/-/SCC) & Old-growth, conifer, mixed forests. \\
\hline Taxidea taxus & $\begin{array}{l}\text { American } \\
\text { badger }\end{array}$ & $(-/-/ \mathrm{SCC})$ & $\begin{array}{l}\text { Cropland/hedgerow, Desert, } \\
\text { Grassland/herbaceous, Savanna, } \\
\text { Shrubland/chaparral }\end{array}$ \\
\hline
\end{tabular}

Source: California Department of Fish and Wildlife, 2013 and NatureServe, 2013. 